Supporting information for

\title{
Solvothermal Alcoholysis Method for Recycling High-Consistency Silicone Rubber Waste
}

Rafał Petrus, ${ }^{\mathrm{a},}$ Józef Utko, ${ }^{\mathrm{b}}$ Radosław Gniłka, ${ }^{\mathrm{c}}$ Mariusz G. Fleszar, ${ }^{\mathrm{c}}$ Tadeusz Lis ${ }^{\mathrm{b}}$ and Piotr Sobotac,*

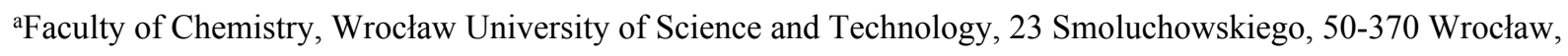
Poland

${ }^{\mathrm{b} F a c u l t y}$ of Chemistry, University of Wrocław, 14 F. Joliot-Curie, 50-383 Wrocław, Poland

čukasiewicz Research Network - PORT Polish Center For Technology Development, 147 Stablowicka, 54-066 Wrocław, Poland

Corresponding author:

Dr. Rafał Petrus, rafal.petrus@pwr.edu.pl

Prof. Dr. Piotr Sobota, piotr.sobota@port.org.pl

\section{Contents}

$\begin{array}{ll}\text { The details of X-ray diffraction study } & \text { S2 }\end{array}$

$\begin{array}{ll}\text { The molecular structures of 2-4 } & \text { S4 }\end{array}$

NMR and IR spectra of 1-6 S5

$\begin{array}{ll}\text { The molecular structures of 8-10 } & \text { S14 }\end{array}$

$\begin{array}{ll}\text { NMR and IR spectra of 7-12 } & \text { S15 }\end{array}$

TGA-DTA, PXRD, NMR study of products formed in SR alcoholysis $\quad$ S25

$\begin{array}{ll}\text { The details of catalyst-free solvothermal SR alcoholysis study } & \text { S27 }\end{array}$

NMR study of products formed in SR alcoholysis under catalyctic conditions $\quad$ S27

$\begin{array}{ll}\text { The details of catalytic solvothermal SR alcoholysis study } & \text { S29 }\end{array}$

Single crystal X-ray diffraction, NMR and IR study of $\mathbf{1 3} \quad$ S30

The details of catalytic solvothermal SR alcoholysis study using C9-C12 fatty alcohols S32 
Crystallographic Data for Compounds 1-13.

Table S1_A. Crystal and data collection parameters for compounds 1-8.

\begin{tabular}{|c|c|c|c|c|}
\hline$\overline{\text { Crystal }}$ & $\mathbf{1} \cdot 2.6 \mathrm{CH}_{2} \mathrm{Cl}_{2}$ & $2 \cdot \mathrm{C}_{2} \mathrm{H}_{5} \mathrm{OH}$ & $7 \cdot 2 \mathrm{THF}$ & $\mathbf{8} \cdot 2 \mathrm{THF}$ \\
\hline Chemical formula & $\mathrm{C}_{54.6} \mathrm{H}_{59.2} \mathrm{I}_{2} \mathrm{Cl}_{5.2} \mathrm{O}_{22} \mathrm{Si}_{2} \mathrm{Zn}_{6}$ & $\mathrm{C}_{42} \mathrm{H}_{54} \mathrm{Mg}_{2} \mathrm{O}_{15}$ & $\mathrm{C}_{56} \mathrm{H}_{58} \mathrm{Li}_{2} \mathrm{Mg}_{2} \mathrm{O}_{20}$ & $\mathrm{C}_{128} \mathrm{H}_{148} \mathrm{Mg}_{4} \mathrm{Na}_{4} \mathrm{O}_{44}$ \\
\hline Formula Mass & 1954.08 & 847.47 & 1113.52 & 1289.83 \\
\hline Crystal system & Triclinic & Monoclinic & Triclinic & Triclinic \\
\hline Space group & $P \overline{1}$ & $P 2_{1} / \mathrm{c}$ & $P \overline{1}$ & $P \overline{1}$ \\
\hline$a / \AA$ & $12.153(3)$ & $15.325(3)$ & $11.256(3)$ & $12.842(3)$ \\
\hline$b / \AA$ & $12.359(3)$ & $15.605(3)$ & $11.970(3)$ & $14.112(3)$ \\
\hline$c / \AA$ & $14.189(4)$ & $36.005(4)$ & $12.208(3)$ & $19.578(3)$ \\
\hline$\alpha /^{\circ}$ & $112.10(3)$ & & $74.86(2)$ & $83.06(3)$ \\
\hline$\beta /^{\circ}$ & $108.14(3)$ & $91.41(2)$ & $64.78(2)$ & $85.31(3)$ \\
\hline$\gamma /{ }^{\circ}$ & $93.93(2)$ & & $63.45(2)$ & $64.38(3)$ \\
\hline Unit cell volume $/ \AA^{3}$ & $1834.3(9)$ & $8608(3)$ & $1326.0(7)$ & $3174.0(13)$ \\
\hline Temperature/K & $100(2)$ & $104(2)$ & $100(2)$ & $100(2)$ \\
\hline$Z$ & 1 & 8 & 1 & 2 \\
\hline Radiation type & $\mathrm{MoK} \alpha$ & $\mathrm{CuK} \alpha$ & $\mathrm{CuK} \alpha$ & $\mathrm{CuK} \alpha$ \\
\hline Absorption coefficient, $\mu / \mathrm{mm}^{-1}$ & 3.061 & 1.077 & 1.085 & 0.130 \\
\hline No. of reflections measured & 14881 & 18787 & 8687 & 26677 \\
\hline No. of independent reflections & 7164 & 18787 & 4988 & 13668 \\
\hline $\begin{array}{l}\text { No. of observed reflections } \\
(I>2 \sigma(I))\end{array}$ & 5227 & 17460 & 4686 & 9286 \\
\hline$R_{\text {int }}$ & 0.0457 & - & 0.0205 & 0.0469 \\
\hline Final $R_{l}$ values $(I>2 \sigma(I))$ & 0.0657 & 0.0693 & 0.0520 & 0.0655 \\
\hline Final $w R\left(F^{2}\right)$ values $(I>2 \sigma(I))$ & 0.2001 & 0.1980 & 0.1424 & 0.1535 \\
\hline Final $R_{I}$ values (all data) & 0.0879 & 0.0735 & 0.0538 & 0.1022 \\
\hline Final $w R\left(F^{2}\right)$ values (all data) & 0.2130 & 0.2026 & 0.1455 & 0.1800 \\
\hline Goodness of fit on $F^{2}$ & 1.047 & 1.109 & 1.023 & 1.048 \\
\hline$\Delta \rho \max / \mathrm{e}^{-3}$ & 1.67 & 0.70 & 0.81 & 0.57 \\
\hline$\Delta \rho \min / \mathrm{e}^{-3}$ & -1.59 & -0.72 & -0.29 & -0.36 \\
\hline
\end{tabular}


Table S1_B. Crystal and data collection parameters for compounds 9-13.

\begin{tabular}{|c|c|c|c|c|}
\hline Crystal & 9 & $\mathbf{1 0} \cdot \mathrm{CH}_{2} \mathrm{Cl}_{2}$ & 11 & $\mathbf{1 3} \cdot \mathrm{CH}_{2} \mathrm{Cl}_{2}$ \\
\hline Chemical formula & $\mathrm{C}_{64} \mathrm{H}_{74} \mathrm{~K}_{2} \mathrm{Mg}_{2} \mathrm{O}_{22}$ & $\mathrm{C}_{50} \mathrm{H}_{46} \mathrm{Li}_{2} \mathrm{O}_{18} \mathrm{Zn}_{2} \mathrm{Cl}_{2}$ & \multicolumn{2}{|c|}{$\mathrm{C}_{56} \mathrm{H}_{58} \mathrm{Na}_{2} \mathrm{O}_{20} \mathrm{Zn}_{2} \mathrm{C}_{68} \mathrm{H}_{64} \mathrm{Na}_{4} \mathrm{O}_{24} \mathrm{Zn}_{2} \mathrm{Cl}_{8}$} \\
\hline Formula Mass & 1322.05 & 1221.29 & 1227.74 & 1771.49 \\
\hline Crystal system & Tetragonal & Triclinic & Triclinic & Monoclinic \\
\hline Space group & $P 4_{2} / \mathrm{n}$ & $P \overline{1}$ & $P \overline{1}$ & $P 2_{1} / \mathrm{n}$ \\
\hline$a / \AA$ & $17.645(3)$ & $11.011(3)$ & $11.298(3)$ & $16.603(2)$ \\
\hline$b / \AA$ & & $11.886(3)$ & $11.637(3)$ & $17.941(3)$ \\
\hline$c / \AA$ & $20.477(3)$ & $12.070(3)$ & $12.267(3)$ & $25.607(5)$ \\
\hline$\alpha /^{\circ}$ & & $74.65(2)$ & $109.29(3)$ & \\
\hline$\beta /^{\circ}$ & & $66.16(2)$ & $104.32(3)$ & $90.30(2)$ \\
\hline$\gamma /{ }^{\circ}$ & & $63.99(2)$ & $99.73(3)$ & \\
\hline Unit cell volume $/ \AA^{3}$ & $6375(2)$ & $1291.2(6)$ & $1418.5(7)$ & $7628(2)$ \\
\hline Temperature/K & $100(2)$ & $100(2)$ & $120(2)$ & $100(2)$ \\
\hline$Z$ & 4 & 1 & 1 & 4 \\
\hline Radiation type & $\mathrm{CuK} \alpha$ & $\operatorname{MoK} \alpha$ & $\operatorname{MoK} \alpha$ & $\operatorname{MoK} \alpha$ \\
\hline Absorption coefficient, $\mu / \mathrm{mm}^{-1}$ & 2.165 & 1.210 & 0.936 & 1.007 \\
\hline No. of reflections measured & 13626 & 14379 & 11045 & 38849 \\
\hline No. of independent reflections & 6130 & 5625 & 5756 & 16639 \\
\hline $\begin{array}{l}\text { No. of observed reflections } \\
(I>2 \sigma(I))\end{array}$ & 5607 & 4983 & 4128 & 13106 \\
\hline$R_{\text {int }}$ & 0.0255 & 0.0486 & 0.0521 & 0.0257 \\
\hline Final $R_{I}$ values $(I>2 \sigma(I))$ & 0.0403 & 0.0454 & 0.0745 & 0.0383 \\
\hline Final $w R\left(F^{2}\right)$ values $(I>2 \sigma(I))$ & 0.1025 & 0.1254 & 0.1932 & 0.0863 \\
\hline Final $R_{l}$ values (all data) & 0.0437 & 0.0494 & 0.0997 & 0.0560 \\
\hline Final $w R\left(F^{2}\right)$ values (all data) & 0.1048 & 0.1286 & 0.2266 & 0.0950 \\
\hline Goodness of fit on $F^{2}$ & 1.063 & 1.093 & 1.044 & 1.040 \\
\hline$\Delta \rho \max / \mathrm{e}^{-3}$ & 0.72 & 1.00 & 0.89 & 0.99 \\
\hline$\Delta \rho \min / \mathrm{e} \AA^{-3}$ & -0.39 & -1.12 & -1.21 & -0.73 \\
\hline
\end{tabular}




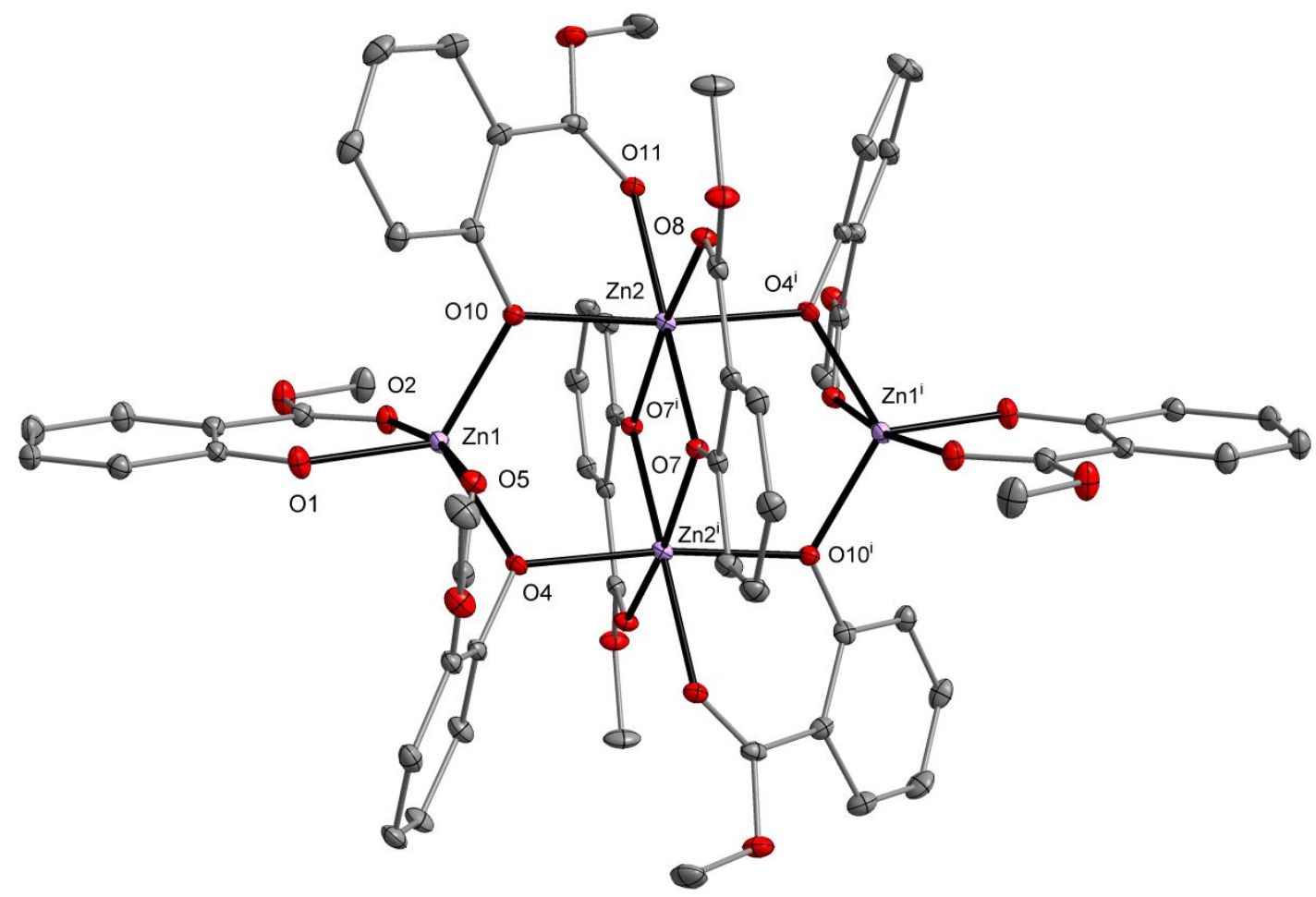

Figure S1. Molecular structures of $\left[\mathrm{Zn}_{4}(\mathrm{MesalO})_{8}\right](2)$ with displacement ellipsoids drawn at the $25 \%$ probability level. The hydrogen atoms are omitted for clarity [symmetry code: (i) $-x+1$, $-\mathrm{y}+1,-\mathrm{z}+1]{ }^{1}$

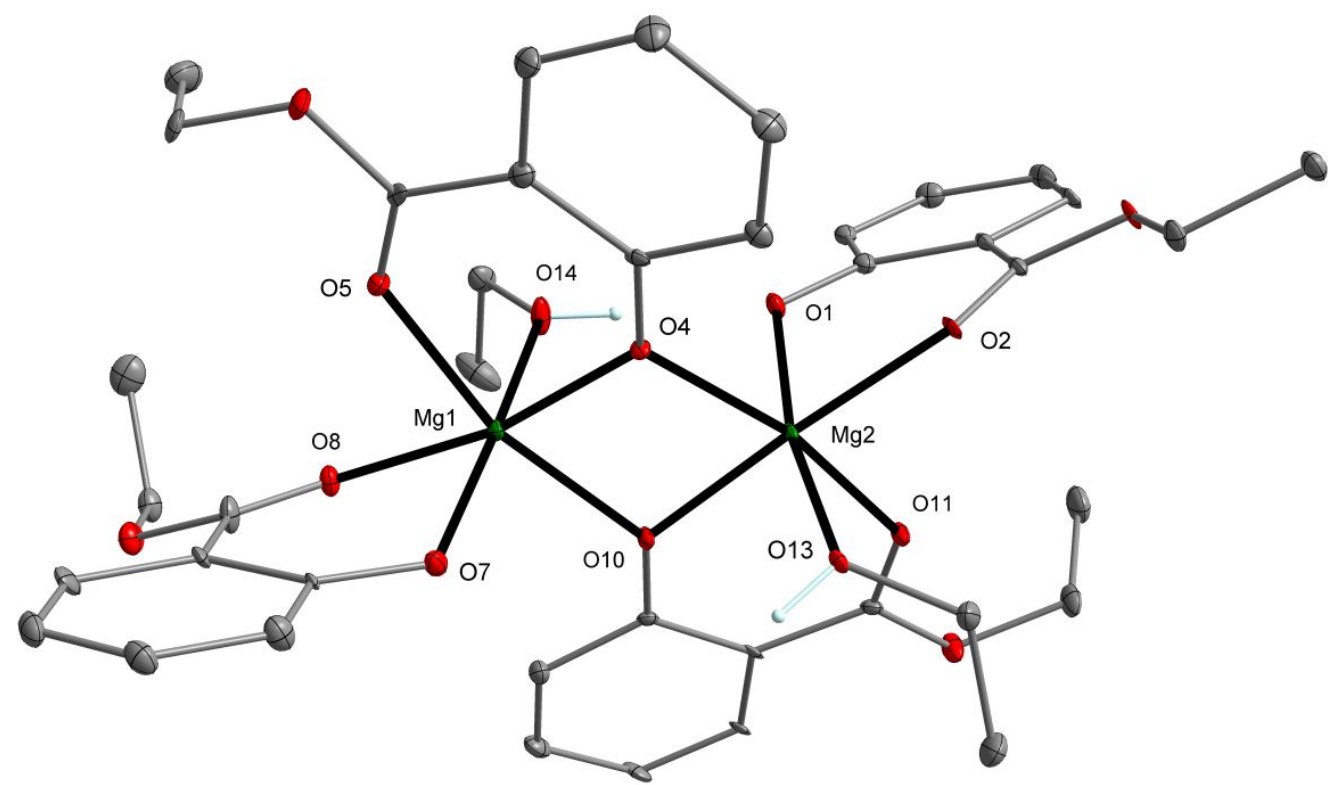

Figure S2. Molecular structures of $\left[\mathrm{Mg}_{2}(\mathrm{EtsalO})_{4}(\mathrm{EtOH})_{2}\right](\mathbf{3})$ with displacement ellipsoids drawn at the $25 \%$ probability level. The hydrogen atoms are omitted for clarity. 


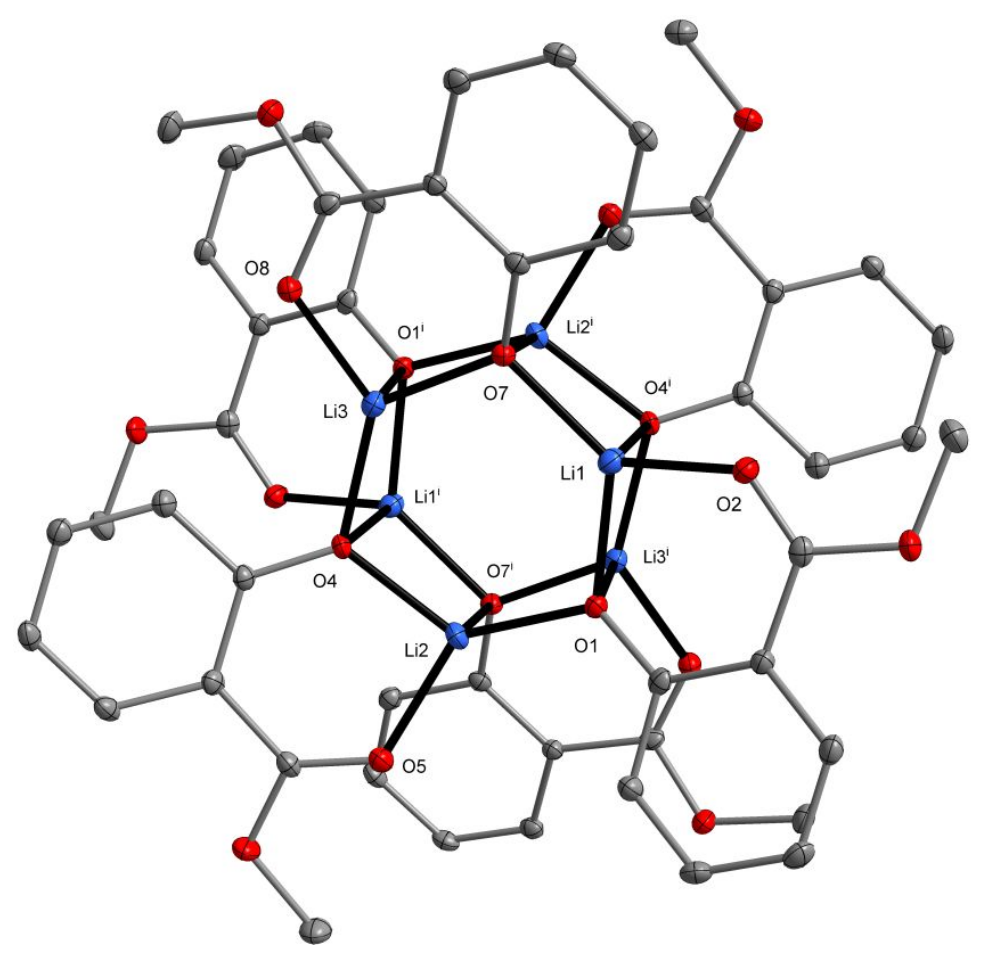

Figure S3. Molecular structures of $\left[\mathrm{Li}_{6}(\mathrm{MesalO})_{6}\right]$ (4) with displacement ellipsoids drawn at the $25 \%$ probability level. The hydrogen atoms are omitted for clarity [symmetry code: (i) $-\mathrm{x}+1,-\mathrm{y}+1,-\mathrm{z}+1]$. Reproduced by permission of The Royal Society of Chemistry. ${ }^{2}$

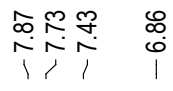

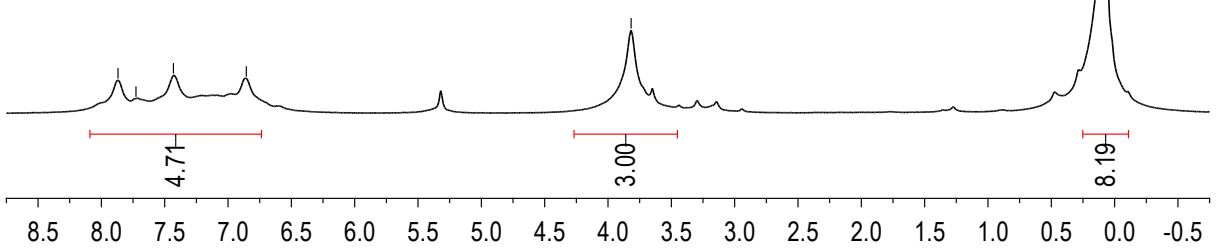

Figure S4. ${ }^{1} \mathrm{H}$ NMR spectrum of 1 in $\mathrm{CD}_{2} \mathrm{Cl}_{2}$. 


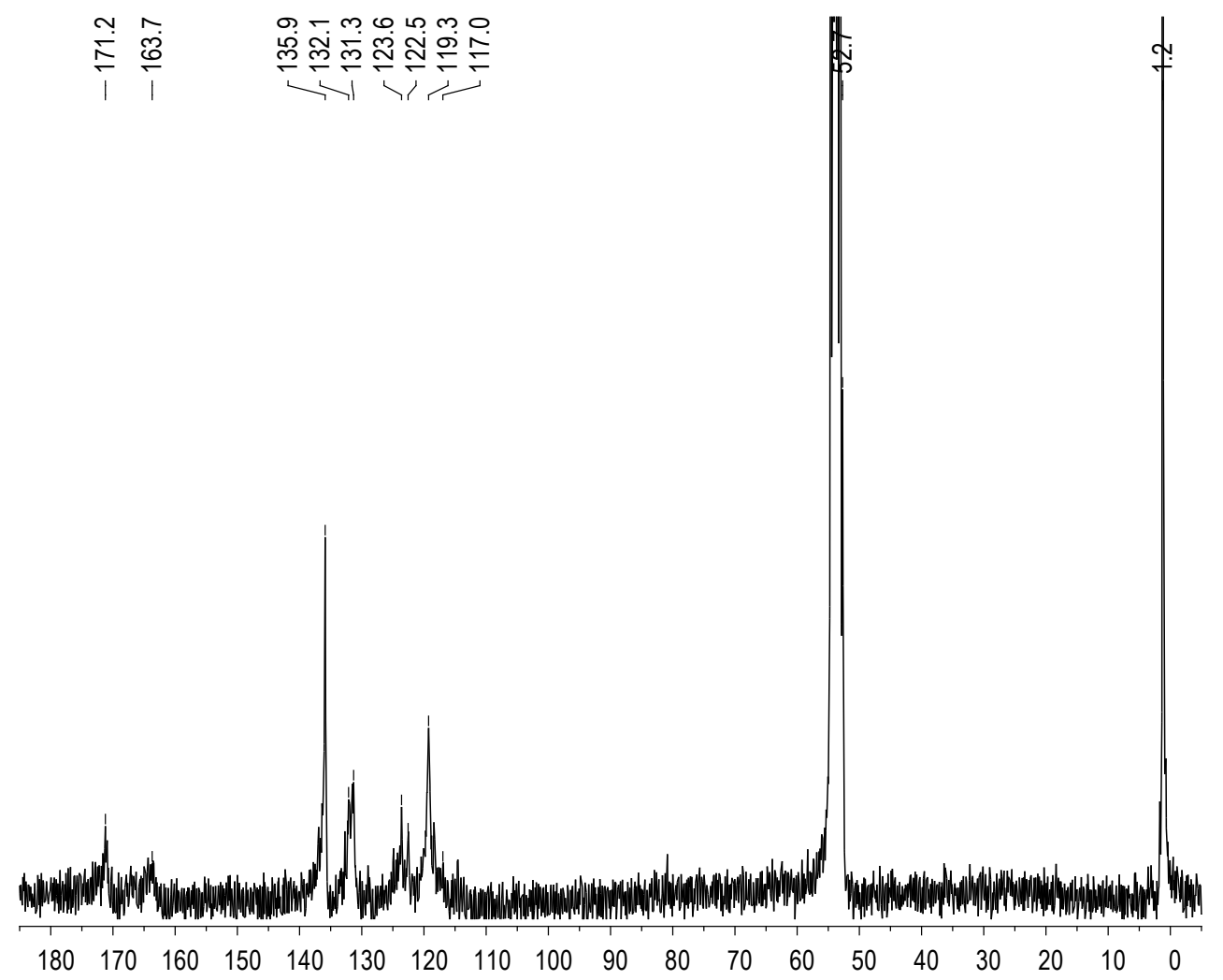

Figure S5. ${ }^{13} \mathrm{C}$ NMR spectrum of 1 in $\mathrm{CD}_{2} \mathrm{Cl}_{2}$.

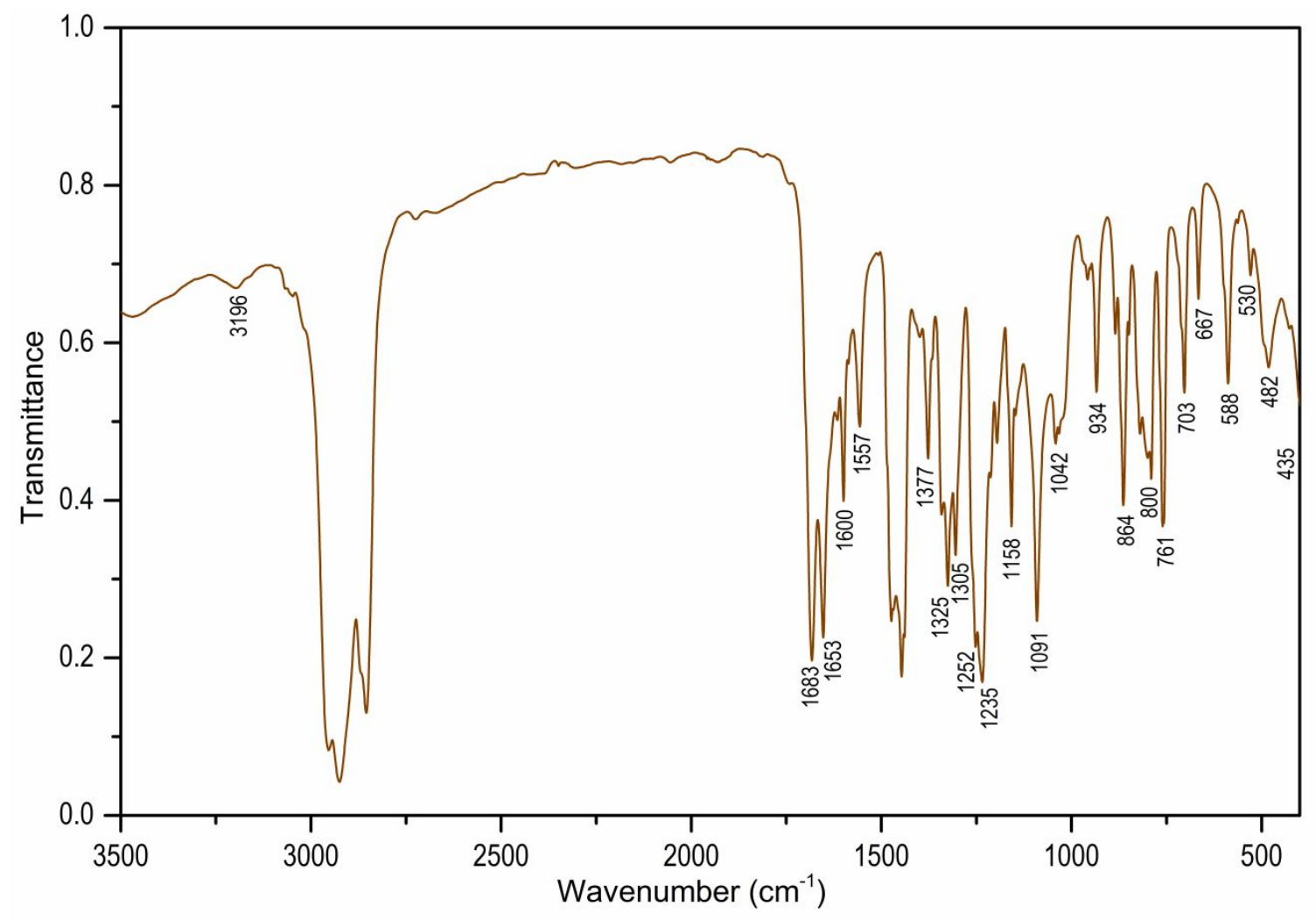

Figure S6. FTIR spectrum of $\mathbf{1}$ in nujol-mull. 


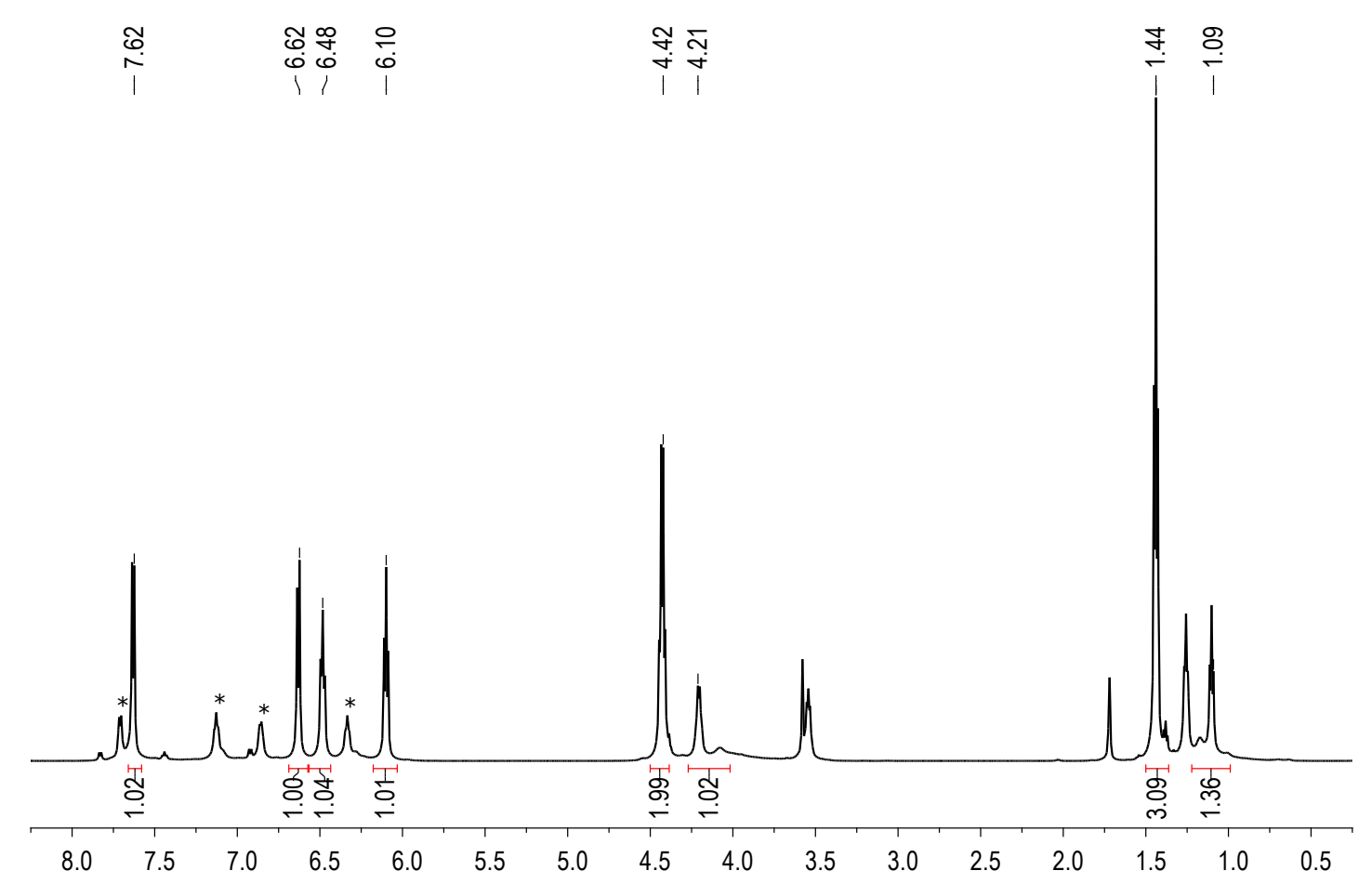

Figure S7. ${ }^{1} \mathrm{H}$ NMR spectrum of $\mathbf{3}$ in $\mathrm{THF}_{-} \mathrm{D}_{8}$ * - means signals from THF-coordinated analog of $\mathbf{3}$.

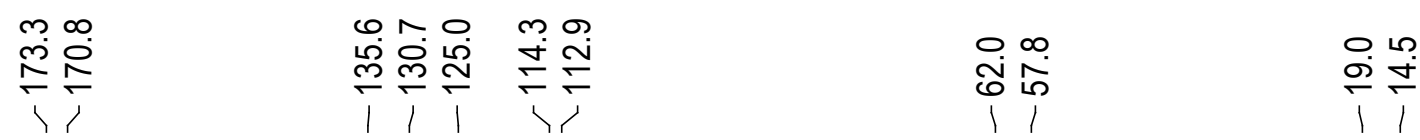

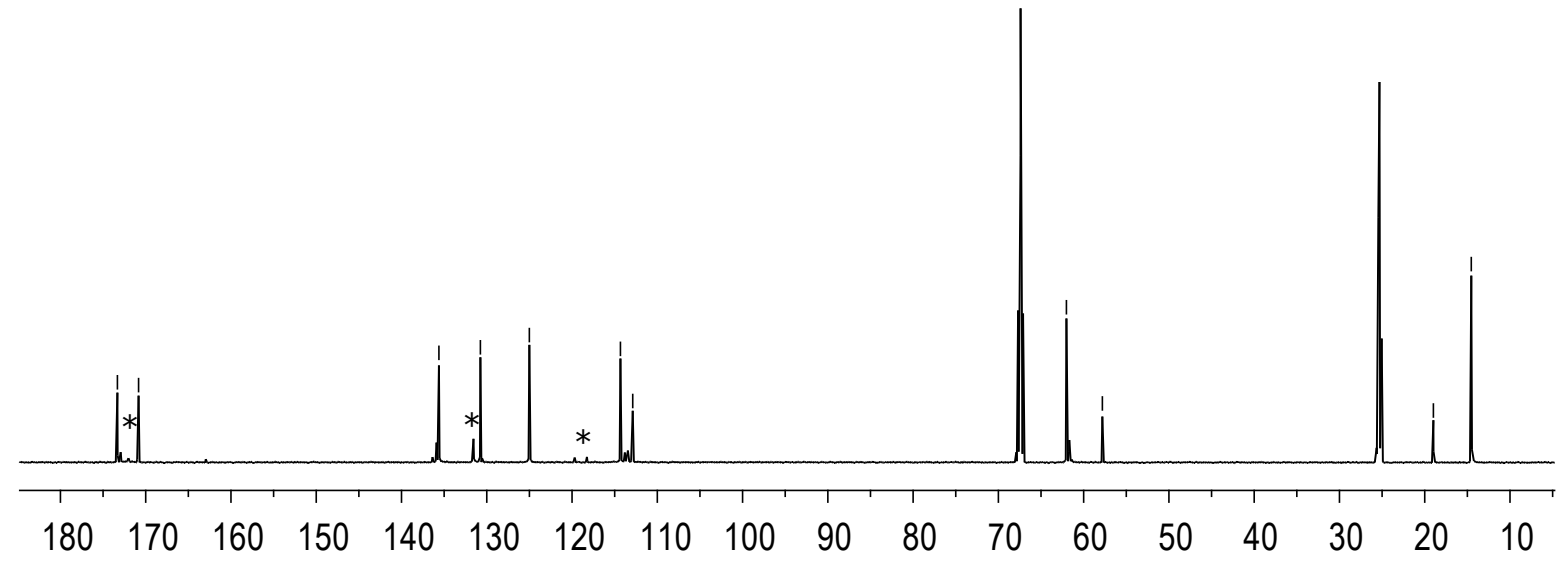

Figure S8. ${ }^{13} \mathrm{C}$ NMR spectrum of 3 in THF-D ${ }_{8} . *$ - means signals from THF-coordinated analog of $\mathbf{3}$. 


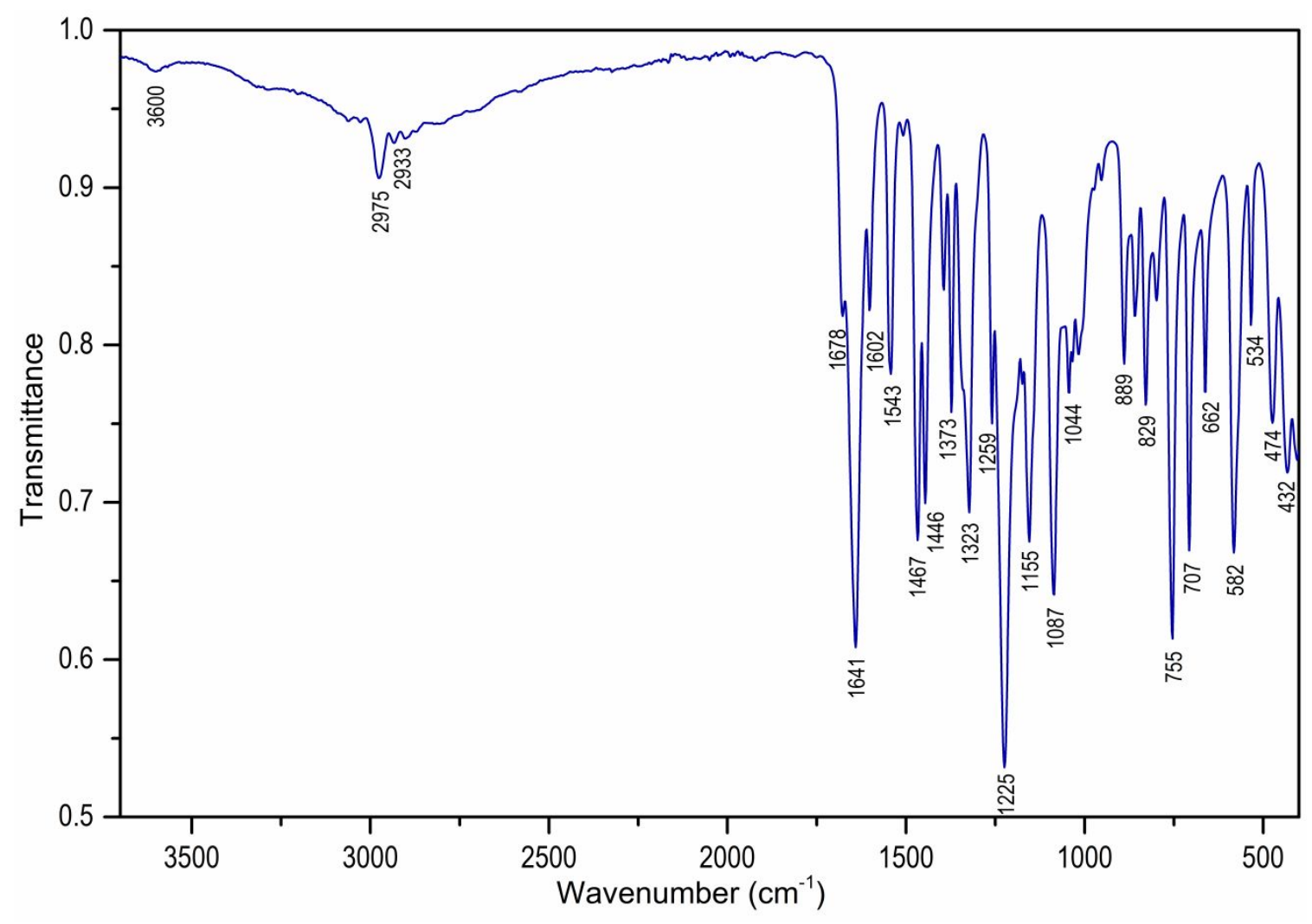

Figure S9. FTIR-ATR spectrum of 3.

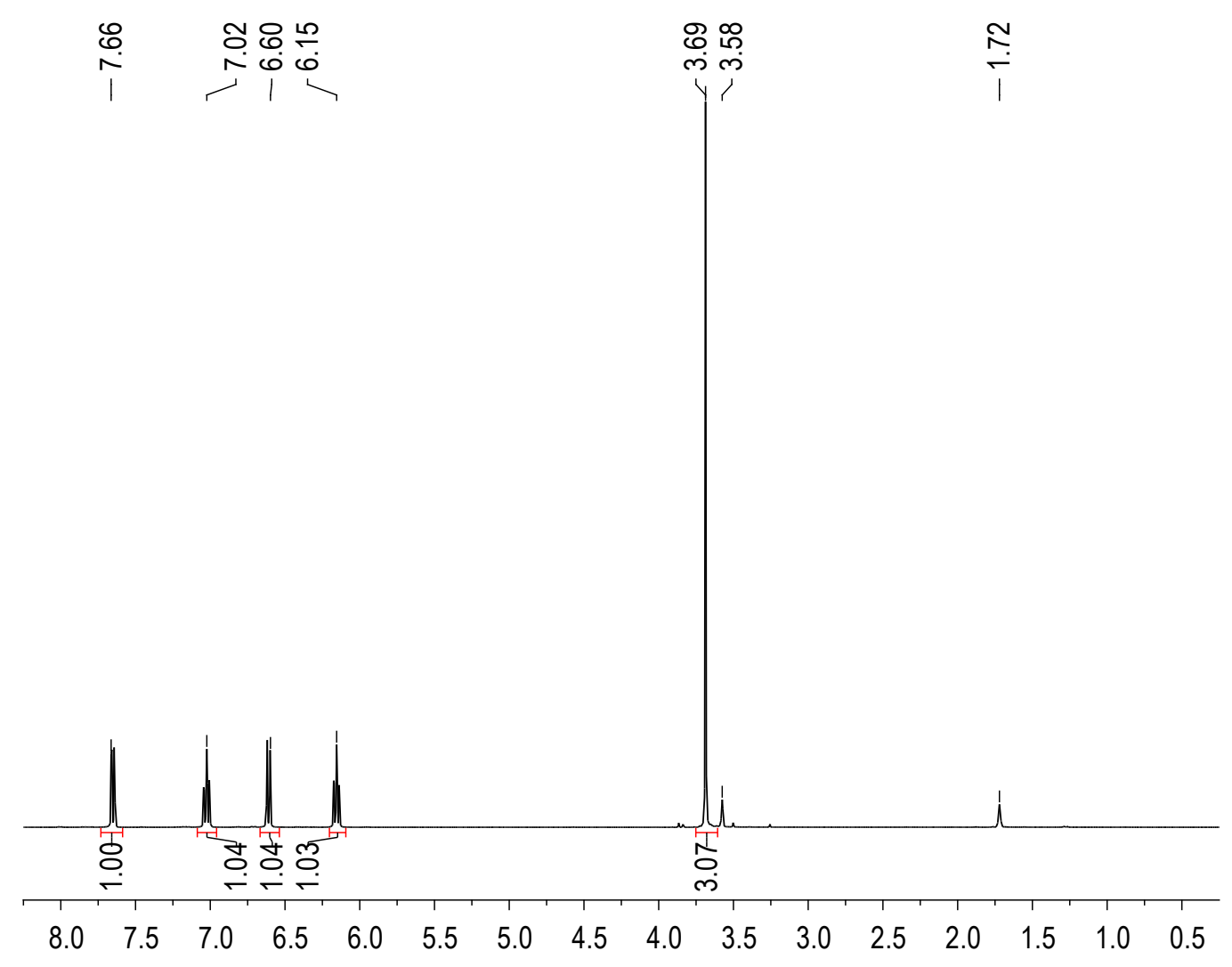

Figure S10. ${ }^{1} \mathrm{H}$ NMR spectrum of 5 in $\mathrm{THF}^{-\mathrm{D}_{8}}$. 


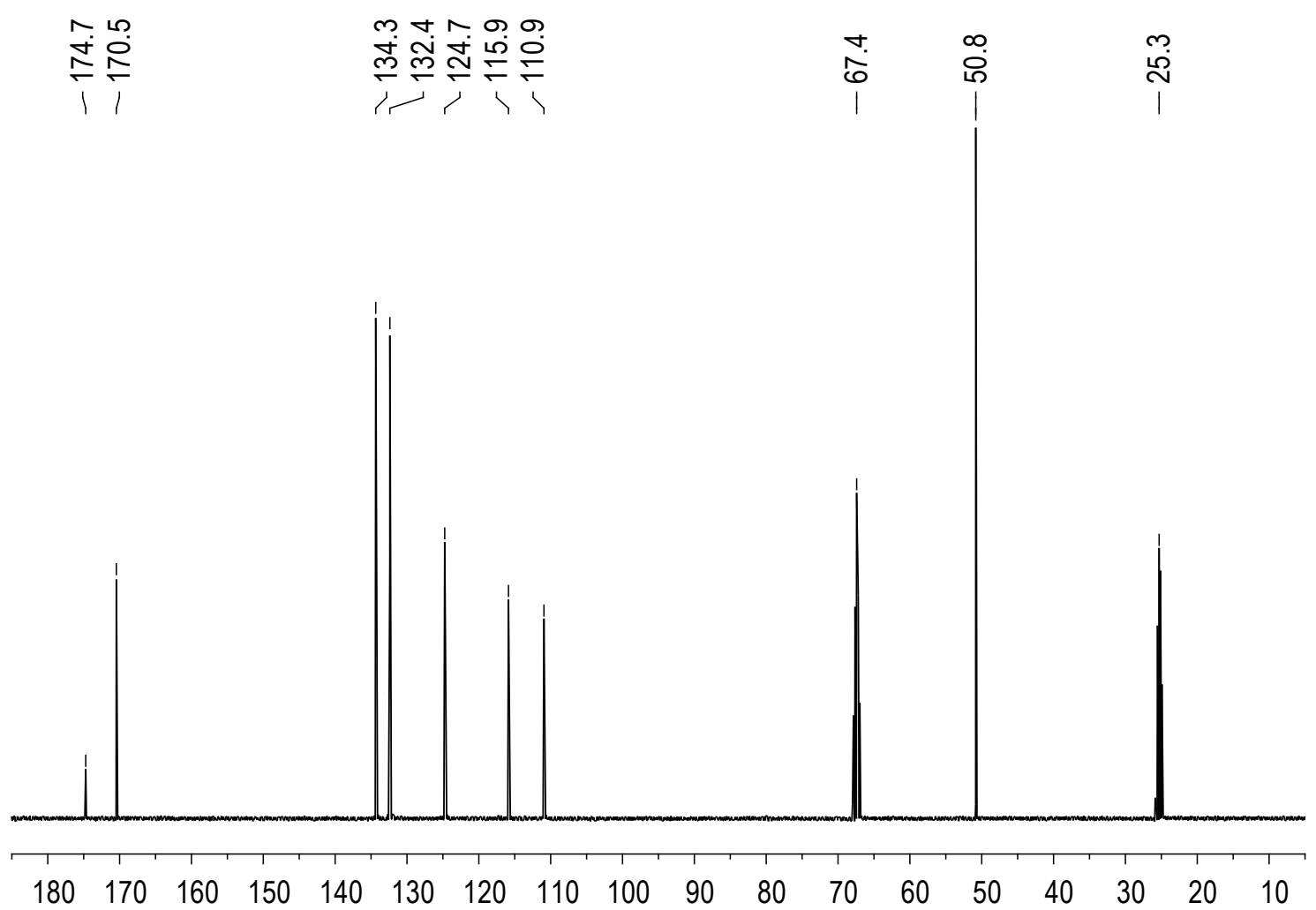

Figure S11. ${ }^{13} \mathrm{C}$ NMR spectrum of 5 in THF-D ${ }_{8}$.

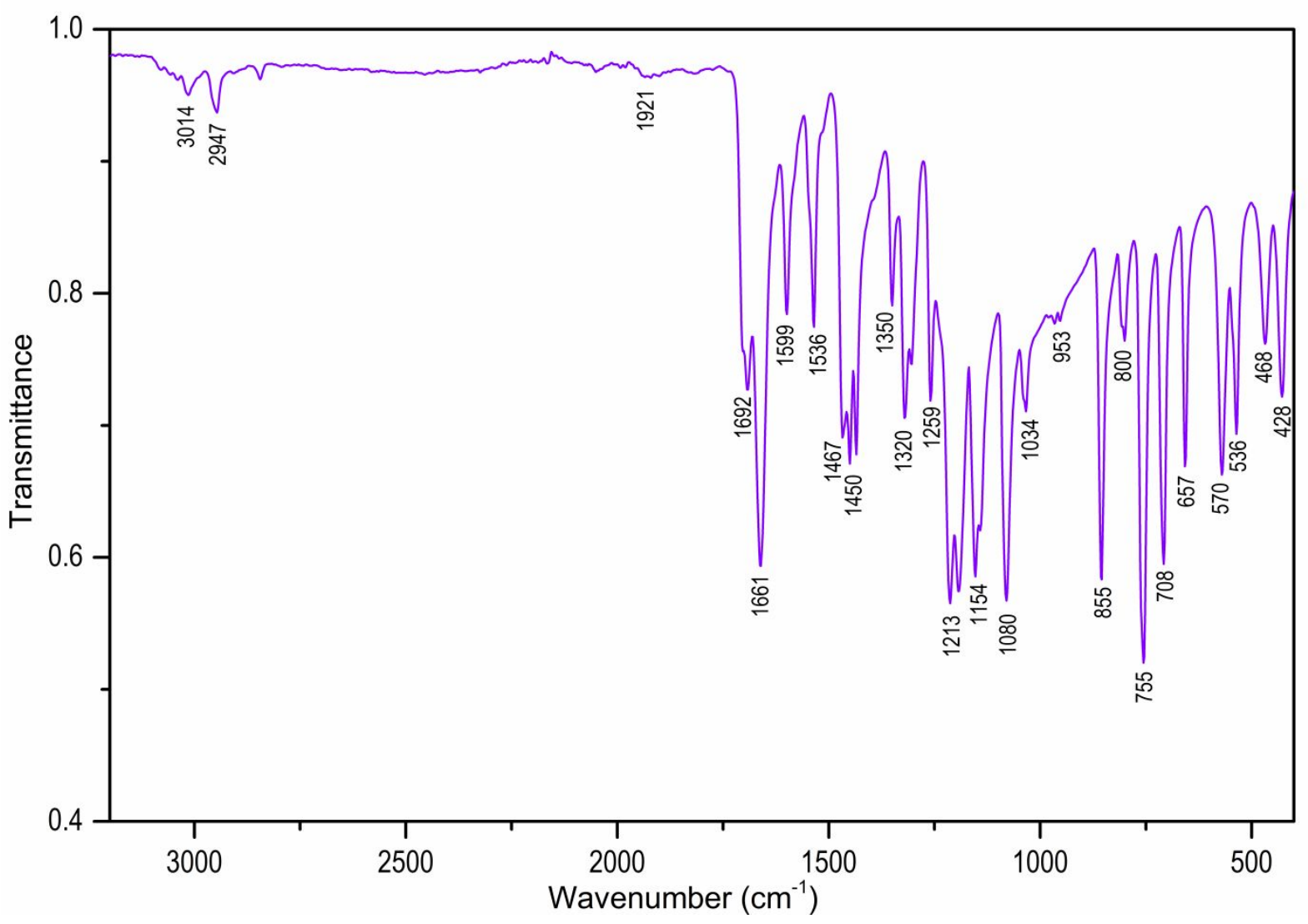

Figure S12. FTIR-ATR spectrum of 5. 


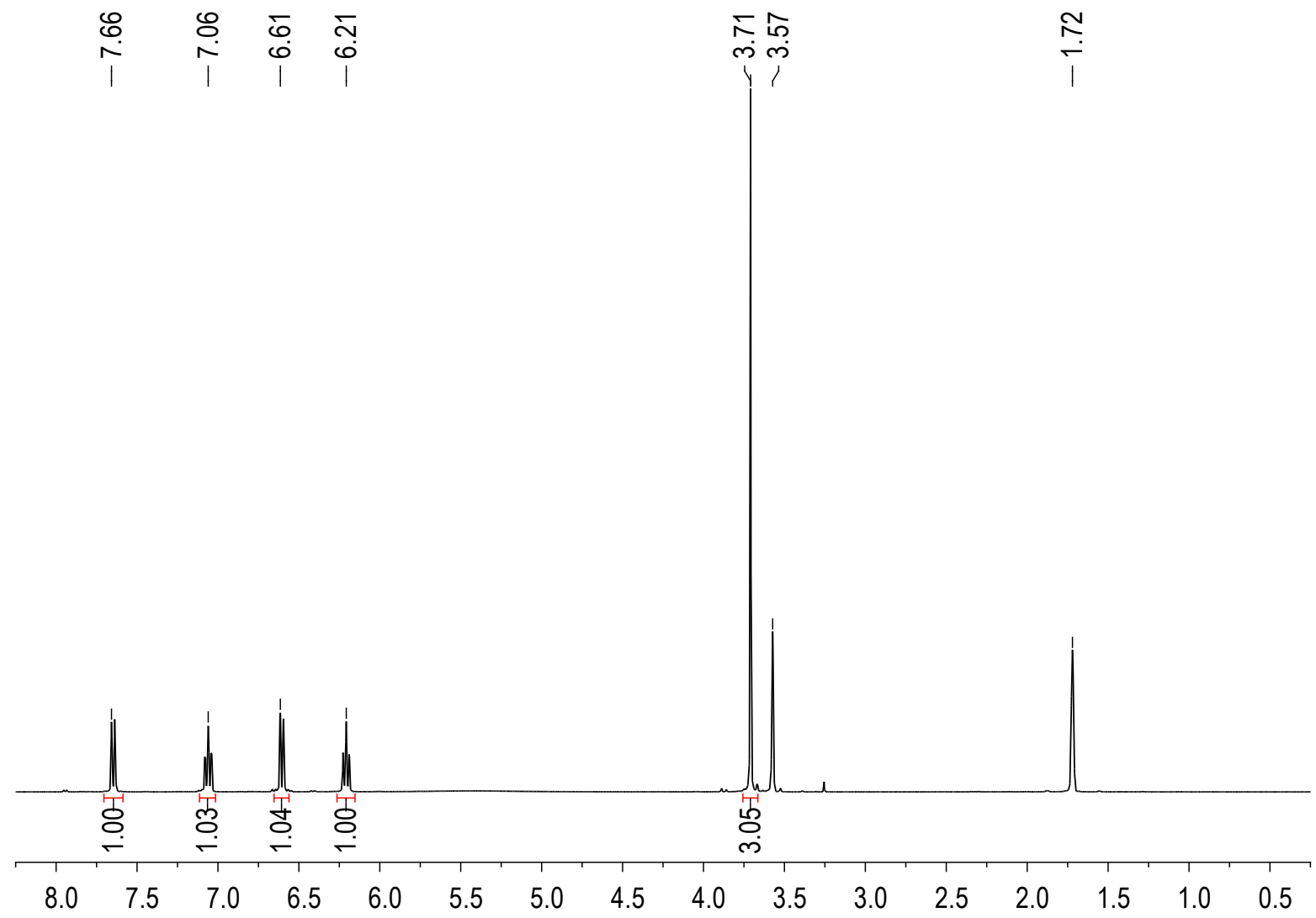

Figure S13. ${ }^{1} \mathrm{H}$ NMR spectrum of 6 in THF-D ${ }_{8}$.

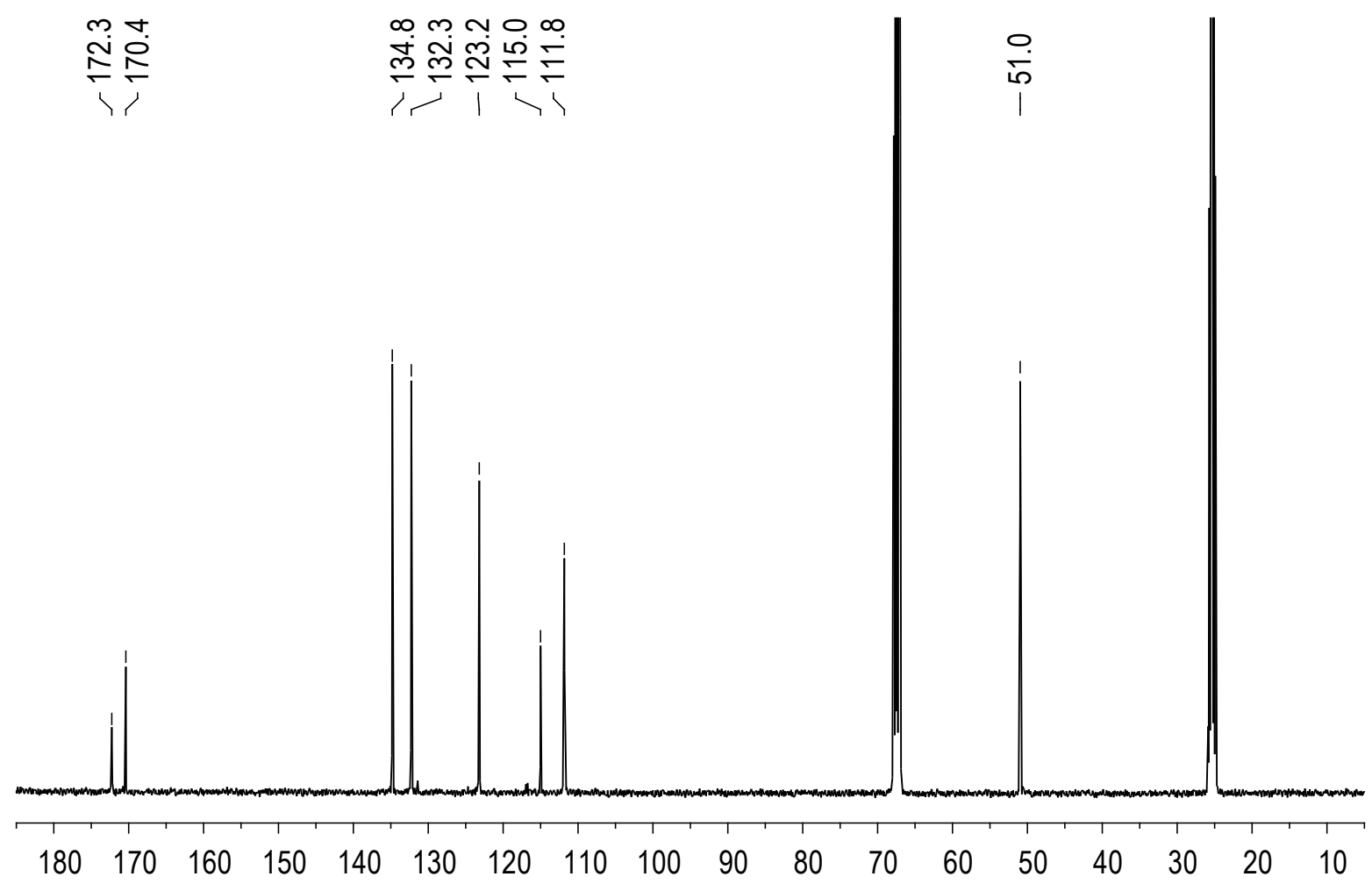

Figure S14. ${ }^{13} \mathrm{C}$ NMR spectrum of 6 in THF-D ${ }_{8}$. 


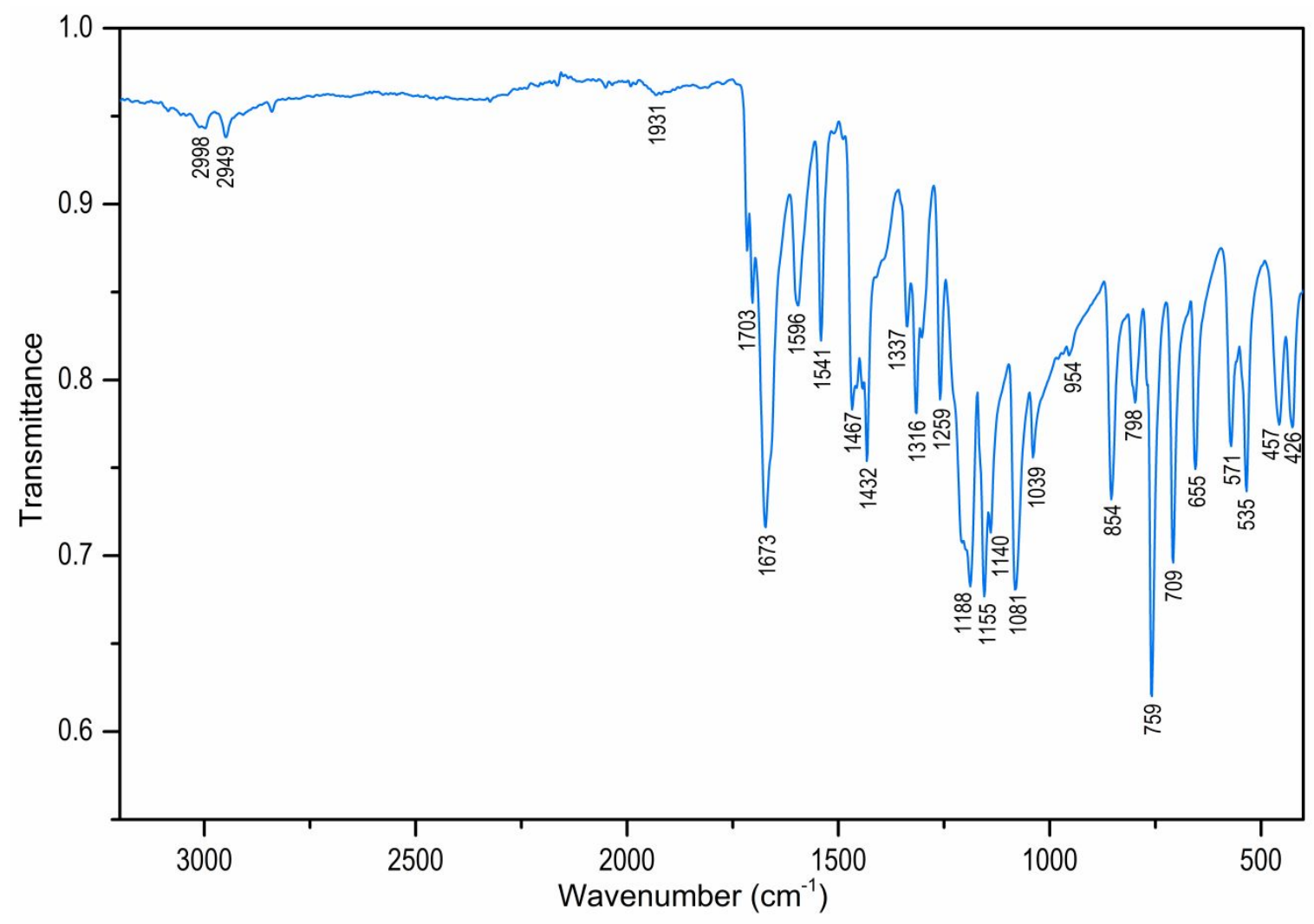

Figure S15. FTIR-ATR spectrum of 6.

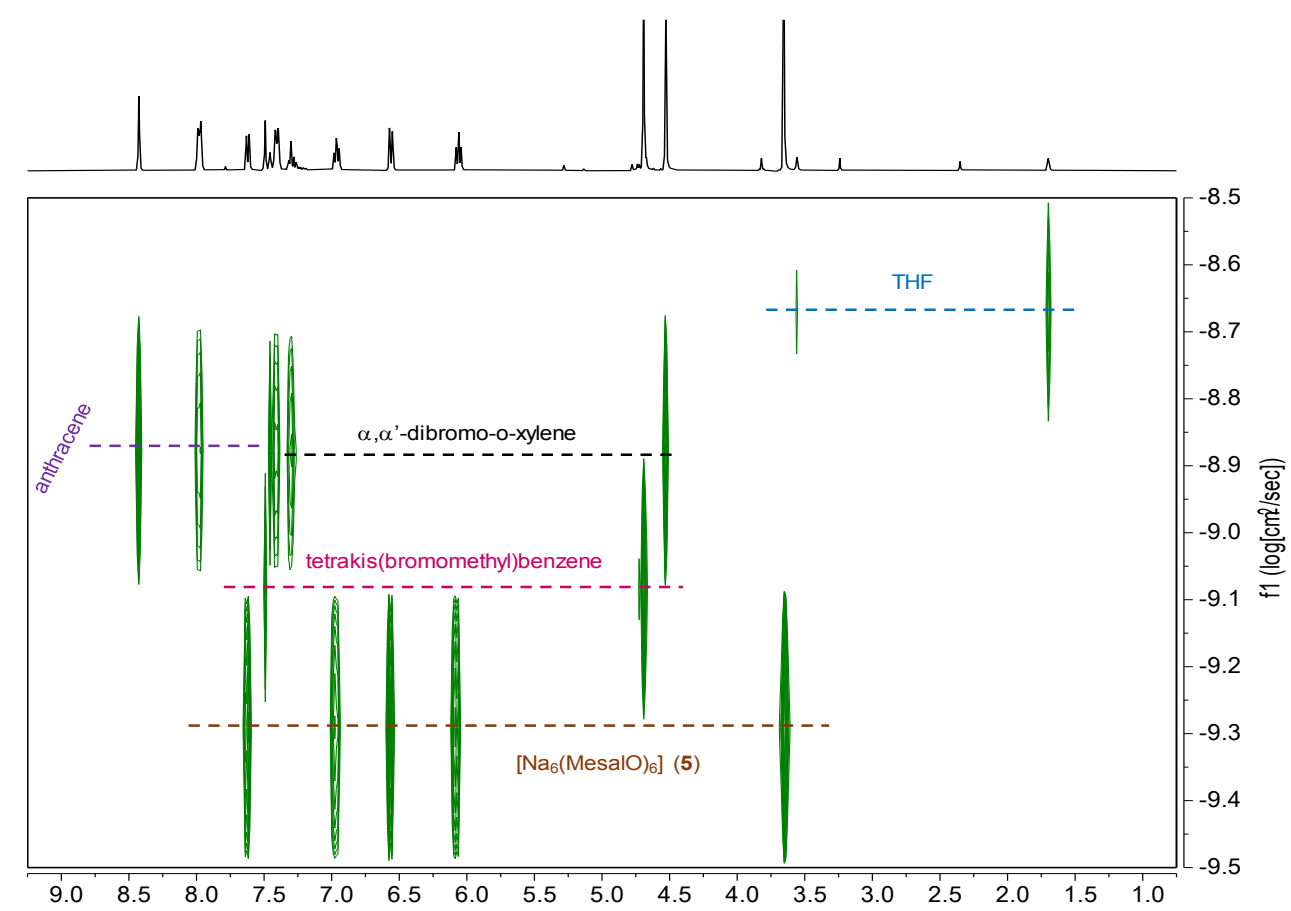

Figure S16. ${ }^{1} \mathrm{H}$ DOSY NMR spectrum of a mixture of anthracene, $\alpha, \alpha$ '-dibromo-o-xylene, 1,2,4,5-tetrakis(bromomethyl)benzene and $\mathbf{5}$ in THF-D ${ }_{8}$. 


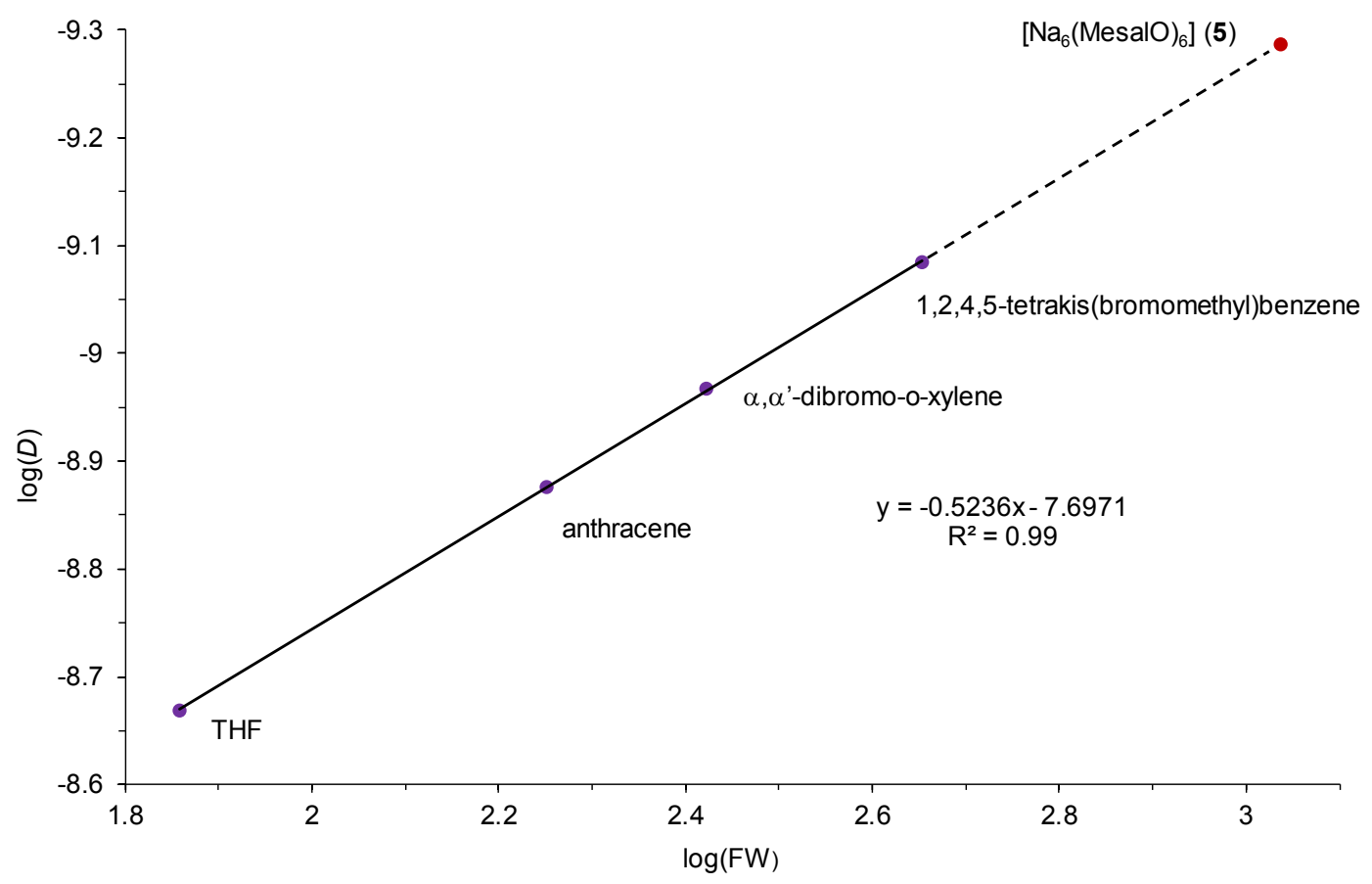

Figure S17. Plot of diffusion coefficient $(\log D)$ versus formula weight $(\log \mathrm{Fw})$ of a mixture of THF, anthracene, $\alpha, \alpha^{\prime}$-dibromo-o-xylene, 1,2,4,5-tetrakis(bromomethyl)benzene and $\mathbf{5}$.

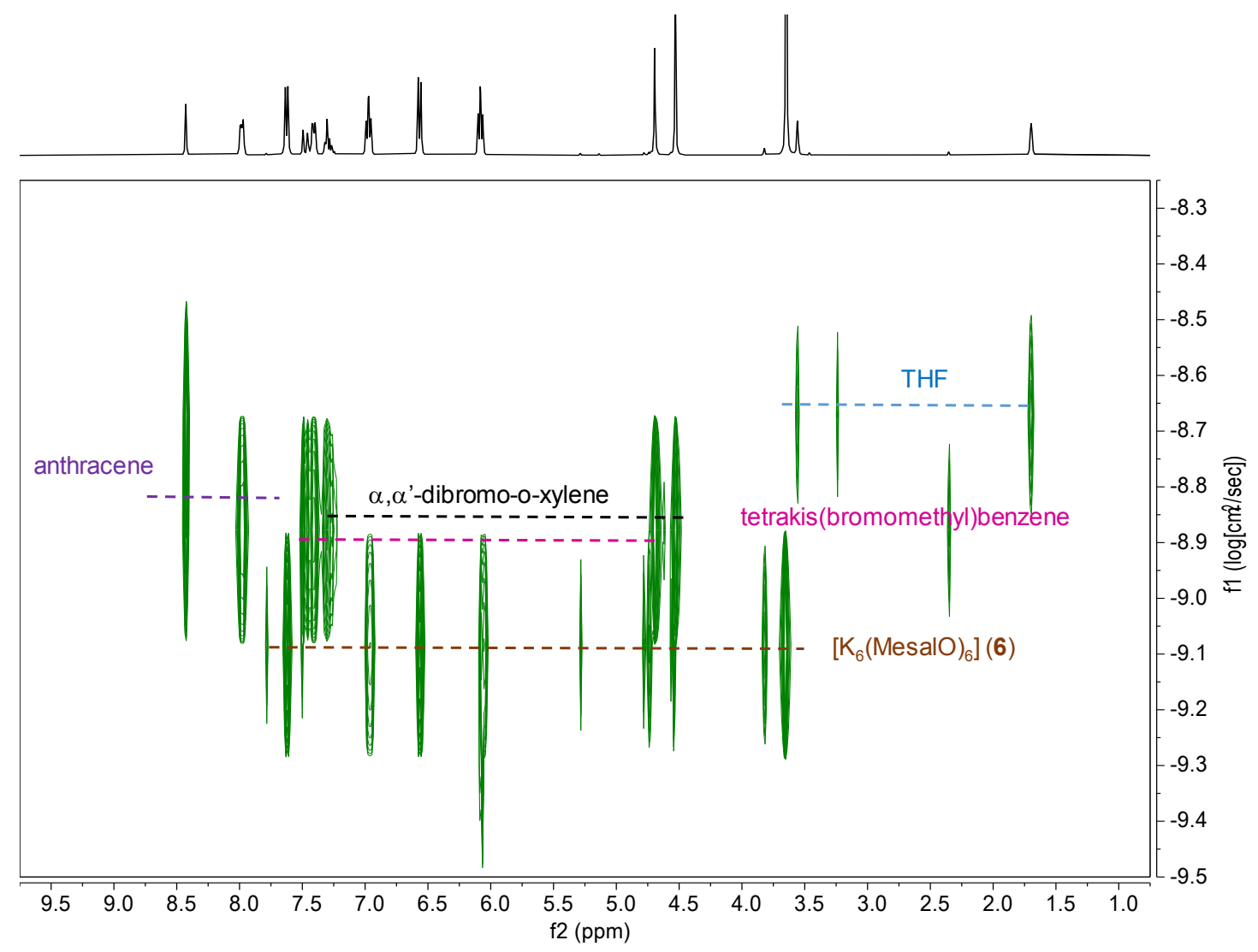

Figure S18. ${ }^{1} \mathrm{H}$ DOSY NMR spectrum of a mixture of anthracene, $\alpha, \alpha$ '-dibromo-o-xylene, 1,2,4,5-tetrakis(bromomethyl)benzene and 6 in THF- $\mathrm{D}_{8}$. 


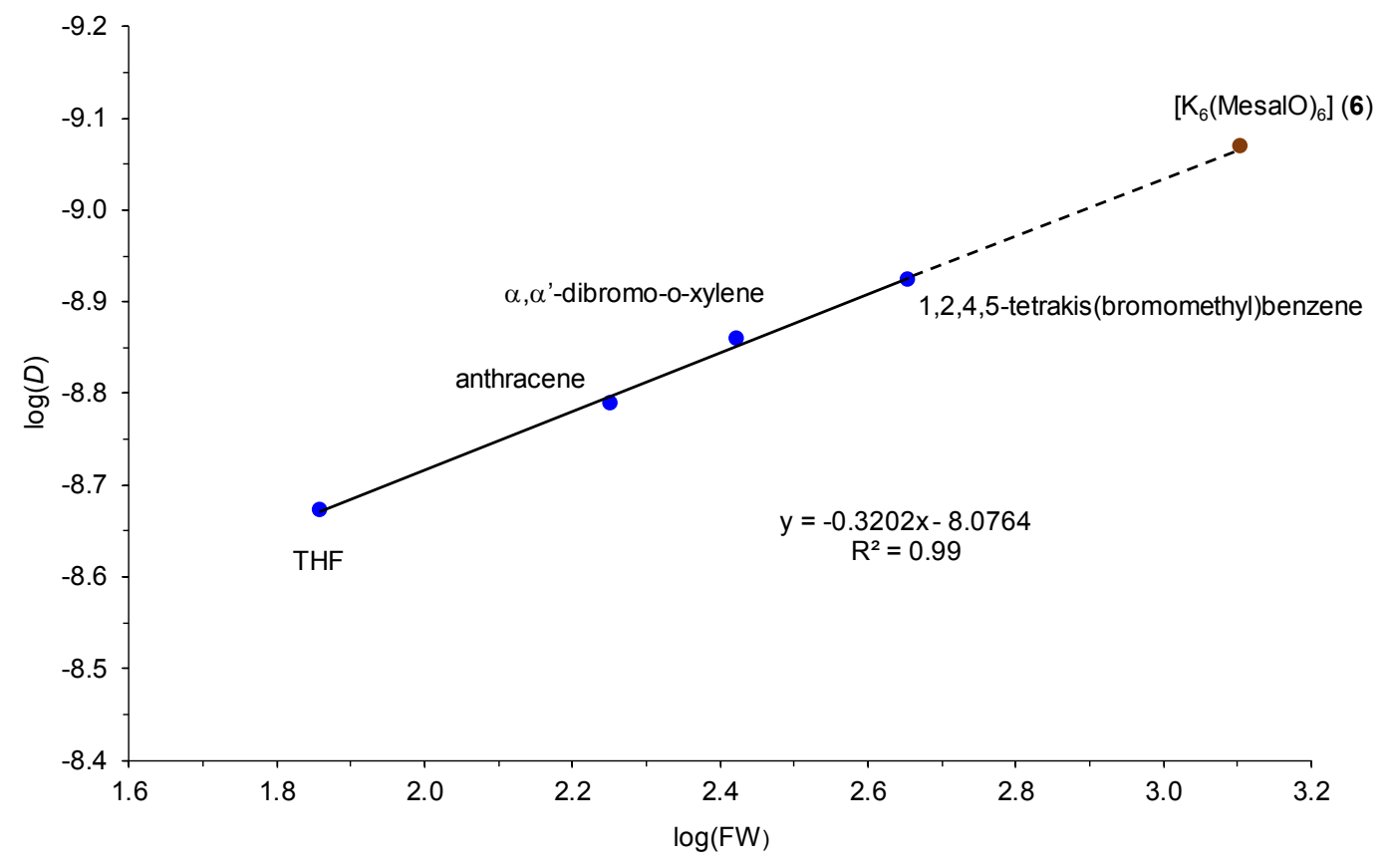

Figure S19. Plot of diffusion coefficient $(\log D)$ versus formula weight ( $\log \mathrm{Fw})$ of a mixture of THF, anthracene, $\alpha, \alpha^{\prime}$-dibromo-o-xylene, 1,2,4,5-tetrakis(bromomethyl)benzene and 6 .

Table. S2 Diffusion coefficients and estimated formula weight for 5-6 at $20{ }^{\circ} \mathrm{C}$.

\begin{tabular}{|c|c|c|c|c|c|}
\hline No. & compound & $10^{-10} D\left(\mathrm{~cm}^{2} / \mathrm{s}\right)$ & Fw $(\mathrm{g} / \mathrm{mol})$ & $F_{w_{\text {estimated }}}(\mathrm{g} / \mathrm{mol})$ & solvent \\
\hline 1. & $\mathbf{5}$ & 9.29 & 1044.77 & 1089 & THF- $\mathrm{d}_{8}$ \\
\hline 2. & $\mathbf{6}$ & 9.08 & 1141.4 & 1270 & THF- $\mathrm{d}_{8}$ \\
\hline
\end{tabular}




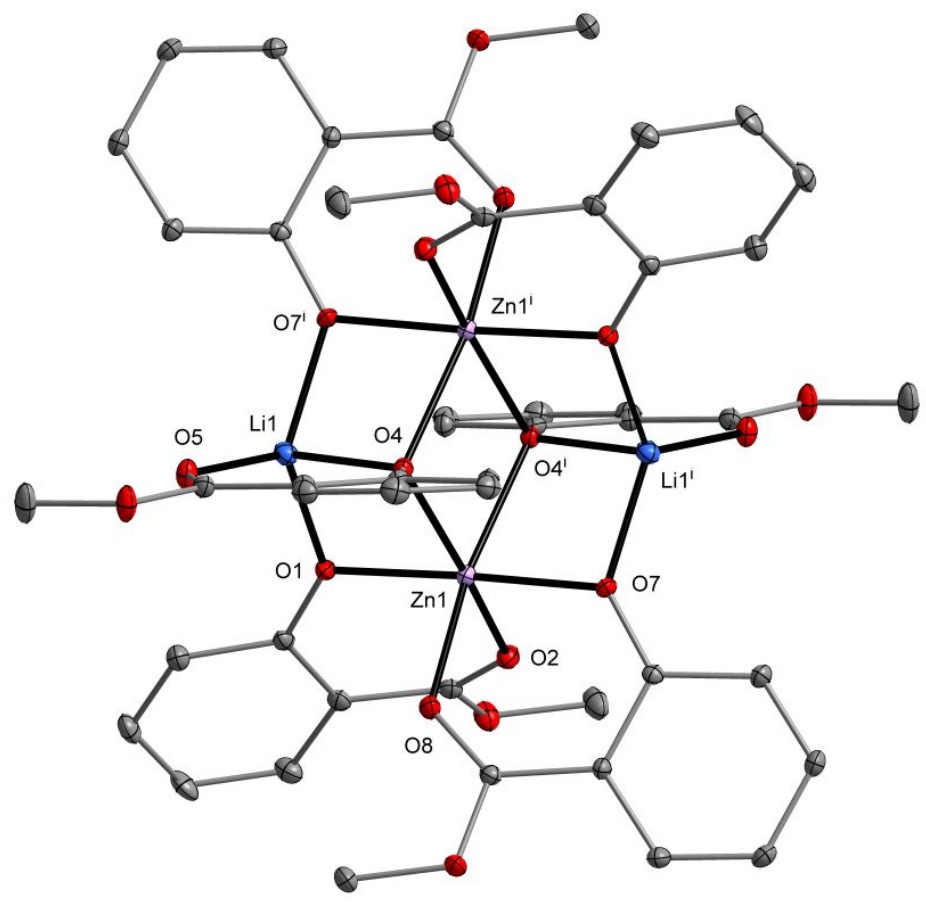

Figure S20. Molecular structures of $\left[\mathrm{Zn}_{2} \mathrm{Li}_{2}(\mathrm{MesalO})_{6}\right]$ (10) with displacement ellipsoids drawn at the $25 \%$ probability level. The hydrogen atoms are omitted for clarity [symmetry code: (i) $-\mathrm{x}+1,-\mathrm{y}+1,-\mathrm{z}+1]$.
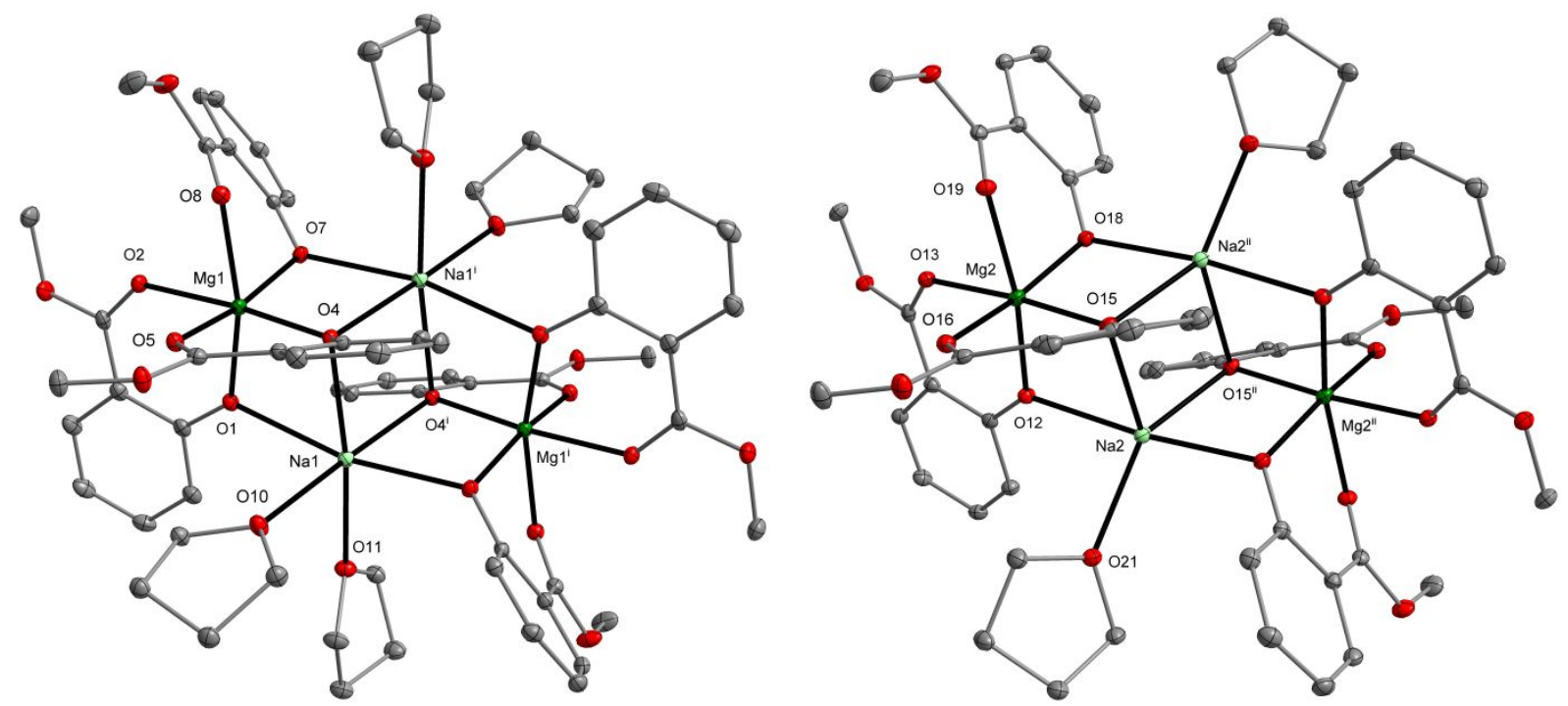

Figure S21. Molecular structures of $\left[\mathrm{Mg}_{2} \mathrm{Na}_{2}(\mathrm{MesalO})_{6}(\mathrm{THF})_{\mathrm{y}}\right]$ (8) for $\mathrm{y}=2$ or 4 with displacement ellipsoids drawn at the $25 \%$ probability level. The hydrogen atoms are omitted for clarity [symmetry code: (i) $-\mathrm{x}+1,-\mathrm{y}+1,-\mathrm{z}+1$; (ii) $-\mathrm{x},-\mathrm{y},-\mathrm{z}]$. 


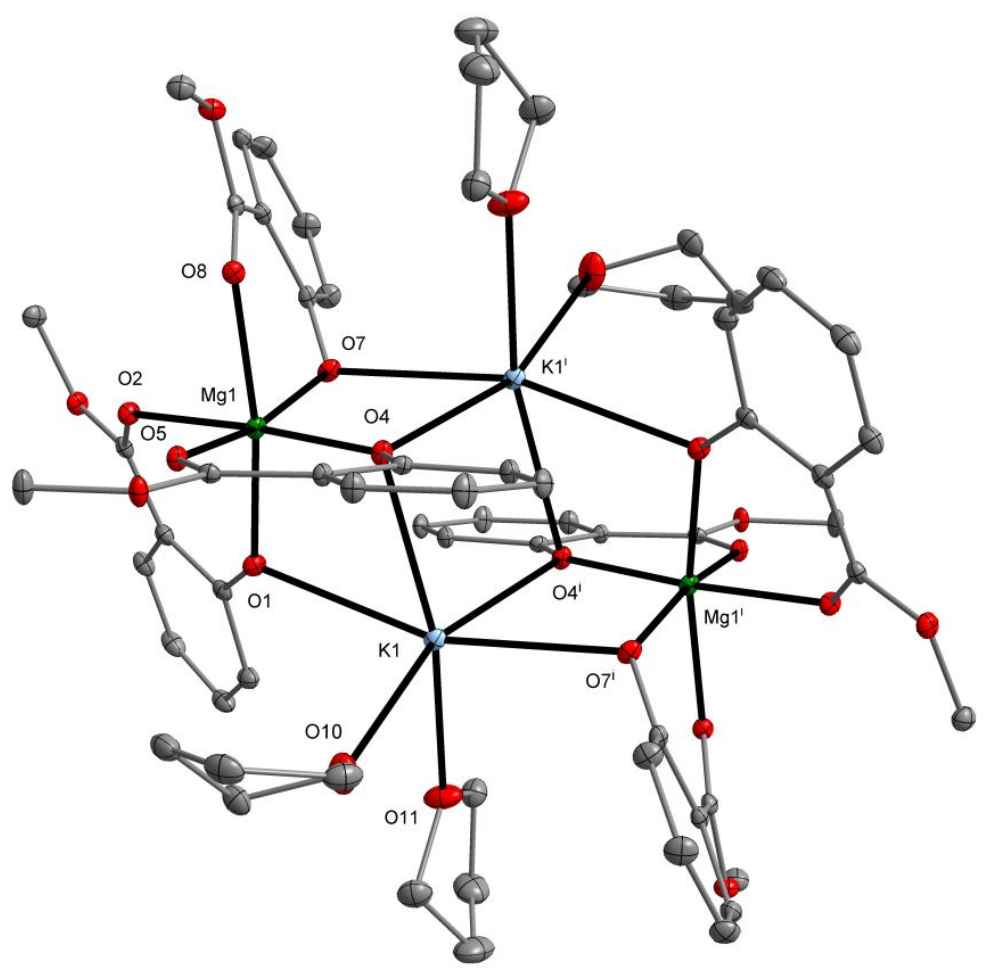

Figure S22. Molecular structures of $\left[\mathrm{Mg}_{2} \mathrm{~K}_{2}(\mathrm{MesalO})_{6}(\mathrm{THF})_{4}\right](\mathbf{9})$ with displacement ellipsoids drawn at the $25 \%$ probability level. The hydrogen atoms are omitted for clarity [symmetry code: (i) $-\mathrm{x}+1,-\mathrm{y}+1,-\mathrm{z}+1]$.

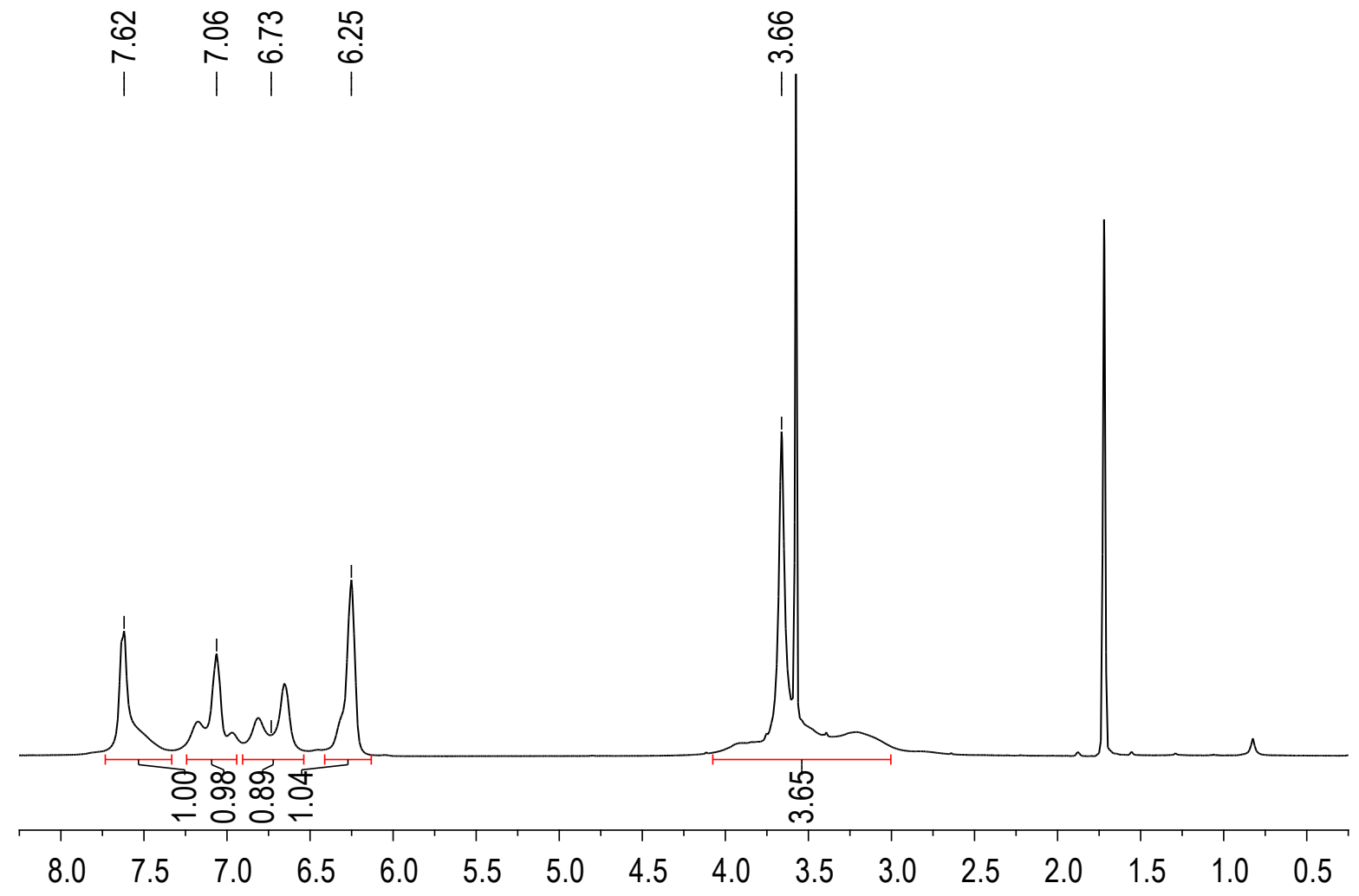

Figure S23. ${ }^{1} \mathrm{H}$ NMR spectrum of 7 in THF- $\mathrm{D}_{8}$. 


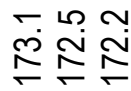

$\infty$ m $\infty$.

$r$

岗

||

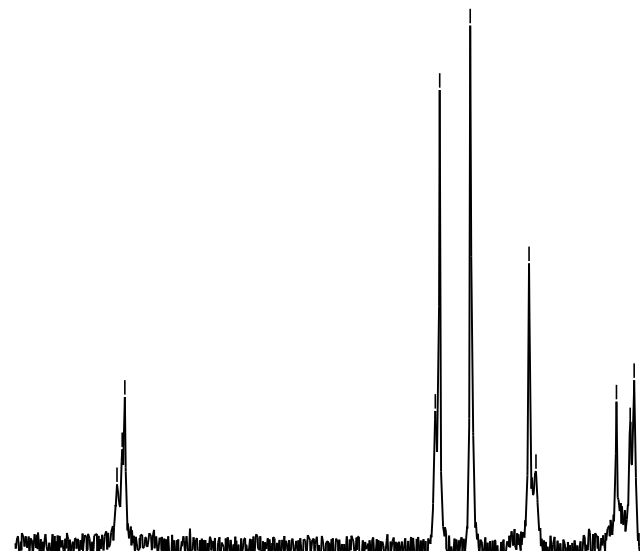

政

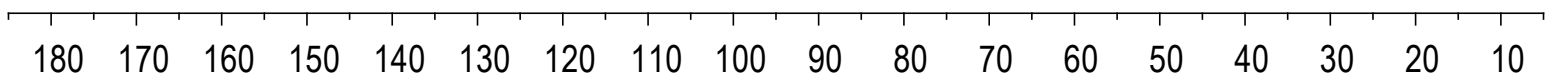

Figure S24. ${ }^{13} \mathrm{C}$ NMR spectrum of 7 in $\mathrm{THF}^{-\mathrm{D}_{8}}$.

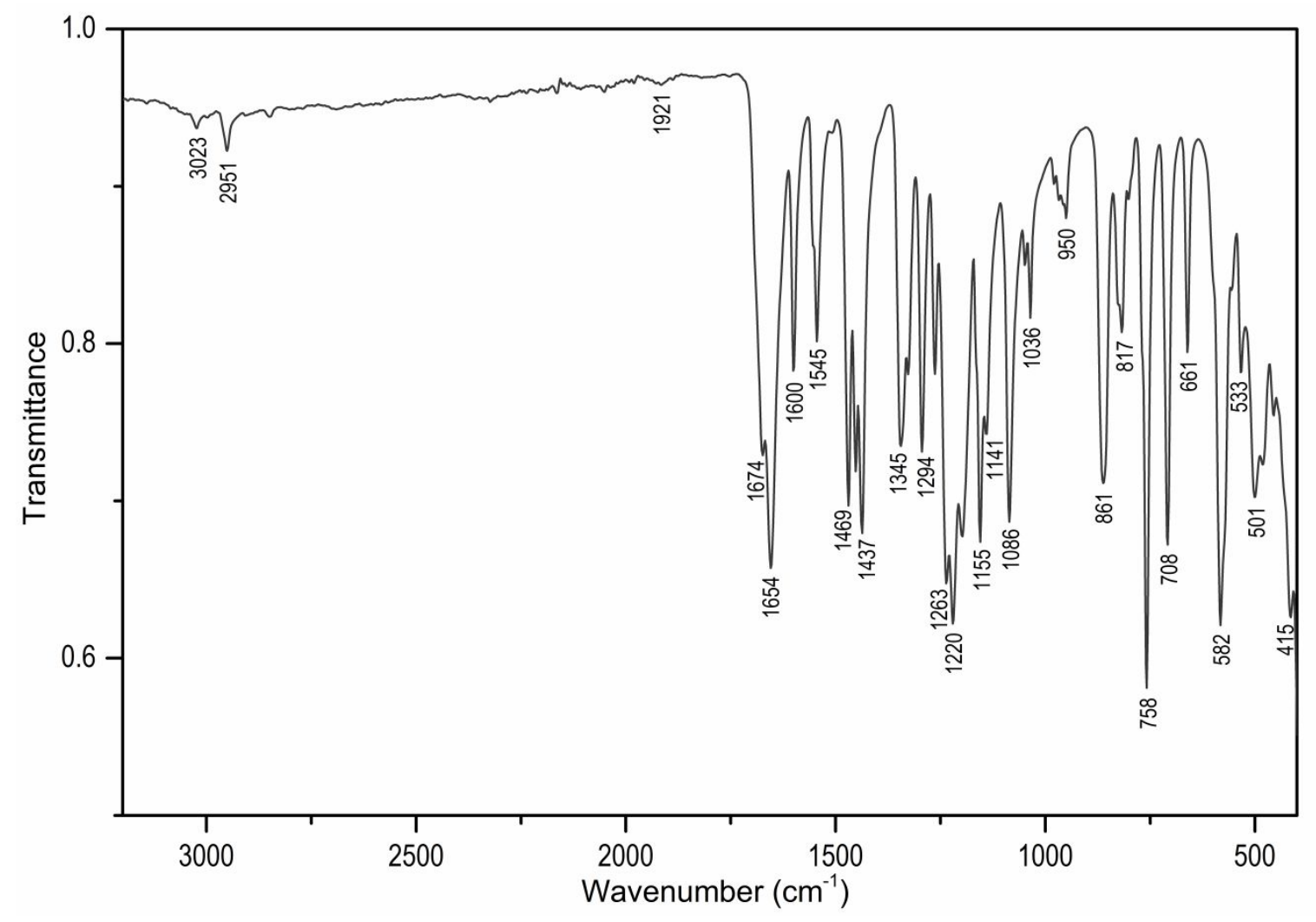

Figure S25. FTIR-ATR spectrum of 7. 


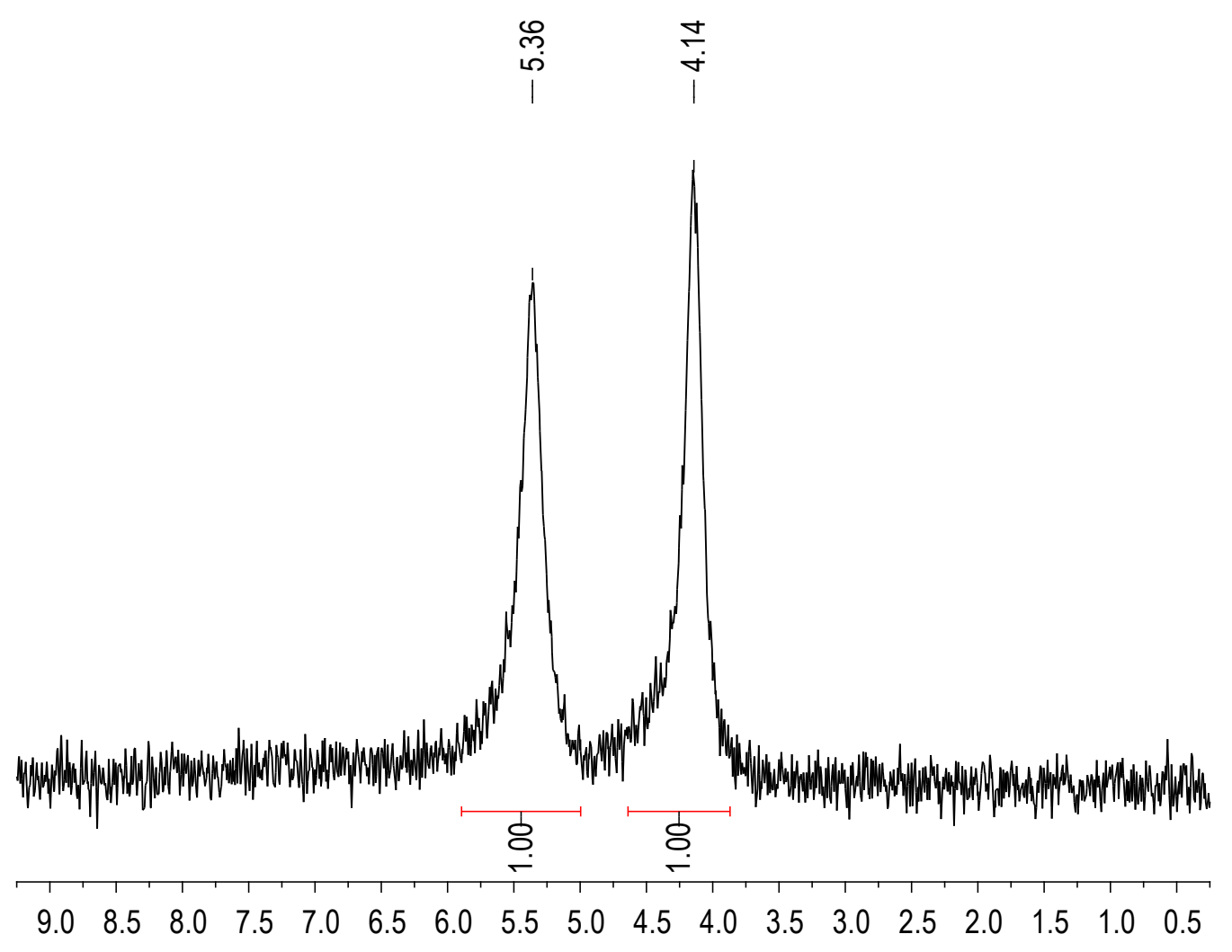

Figure S26. ${ }^{7} \mathrm{Li}$ NMR spectrum of 7 in THF-D ${ }_{8}$.

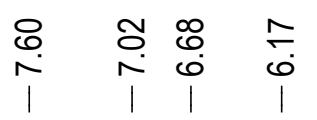

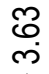

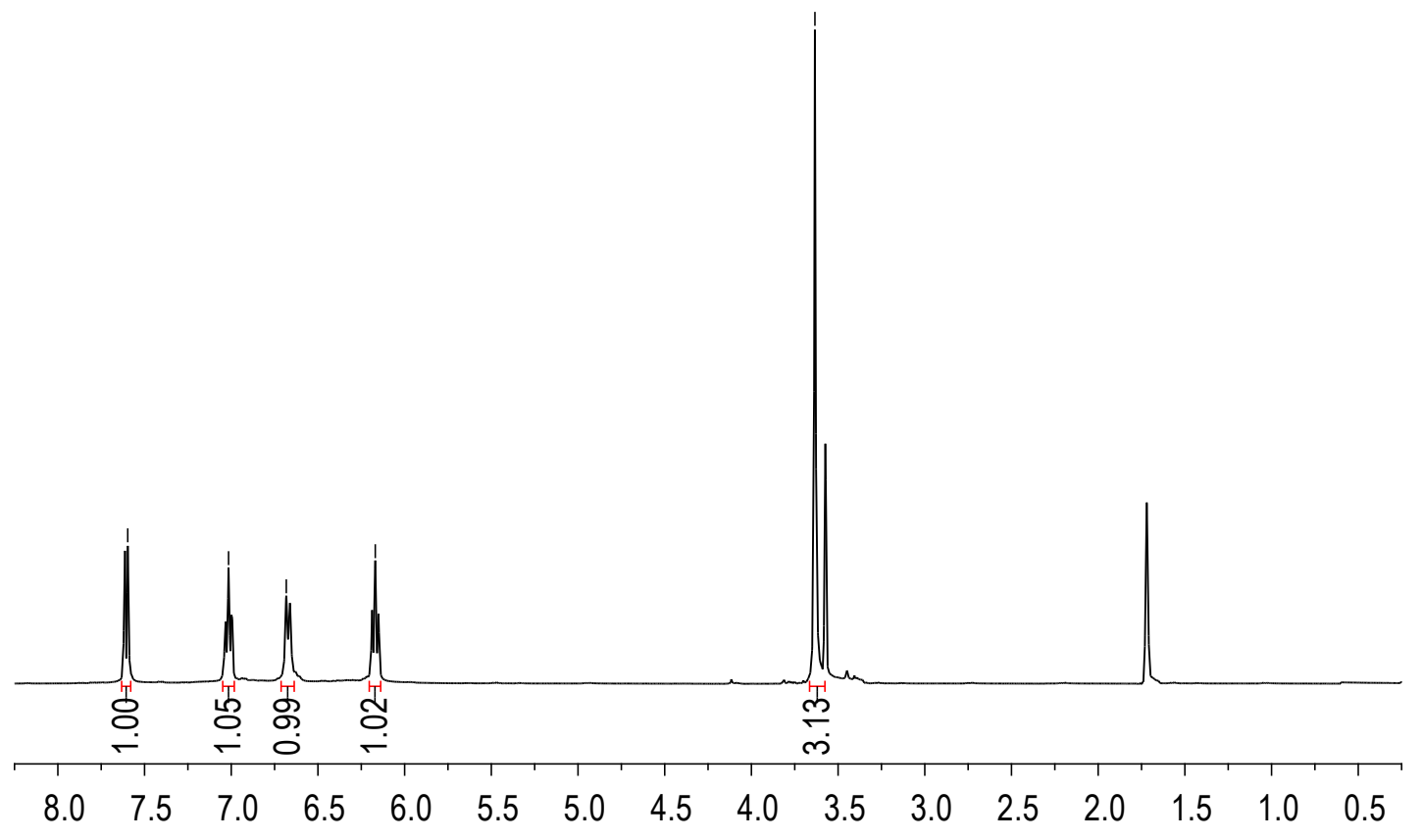

Figure S27. ${ }^{1} \mathrm{H}$ NMR spectrum of 8 in $\mathrm{THF}^{-\mathrm{D}_{8} .}$ 


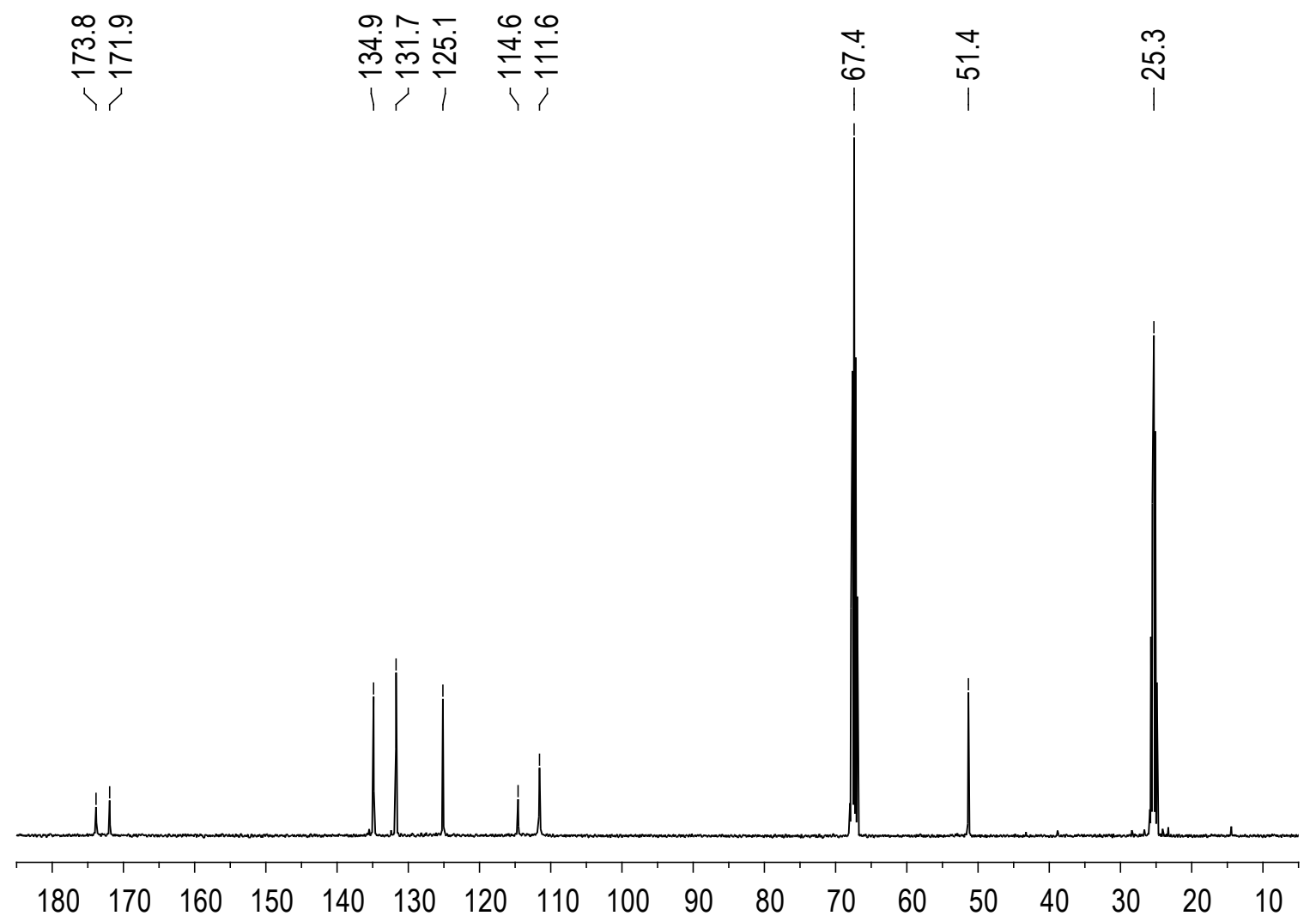

Figure S28. ${ }^{13} \mathrm{C}$ NMR spectrum of 8 in THF-D 8 .

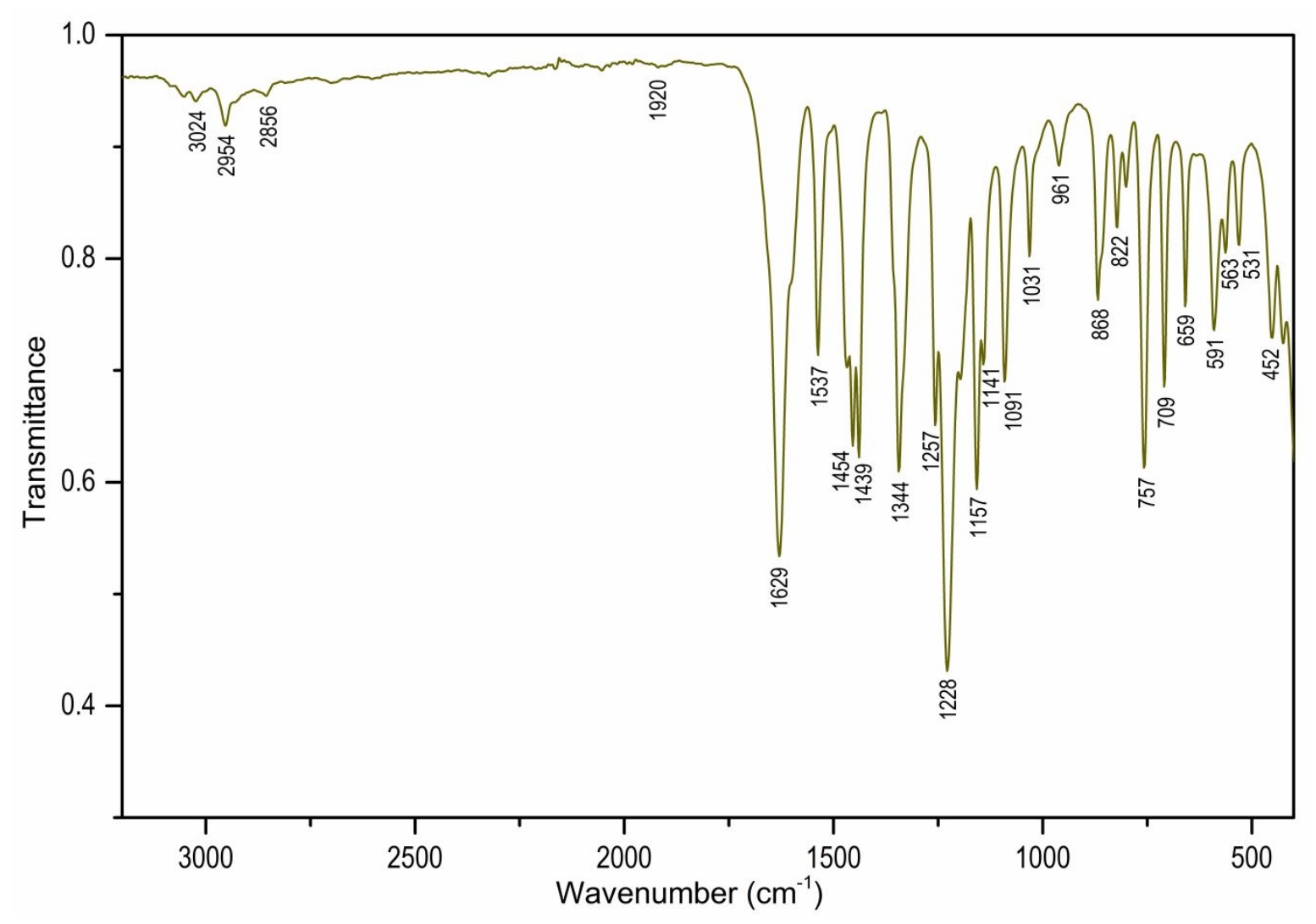

Figure S29. FTIR-ATR spectrum of $\mathbf{8}$. 


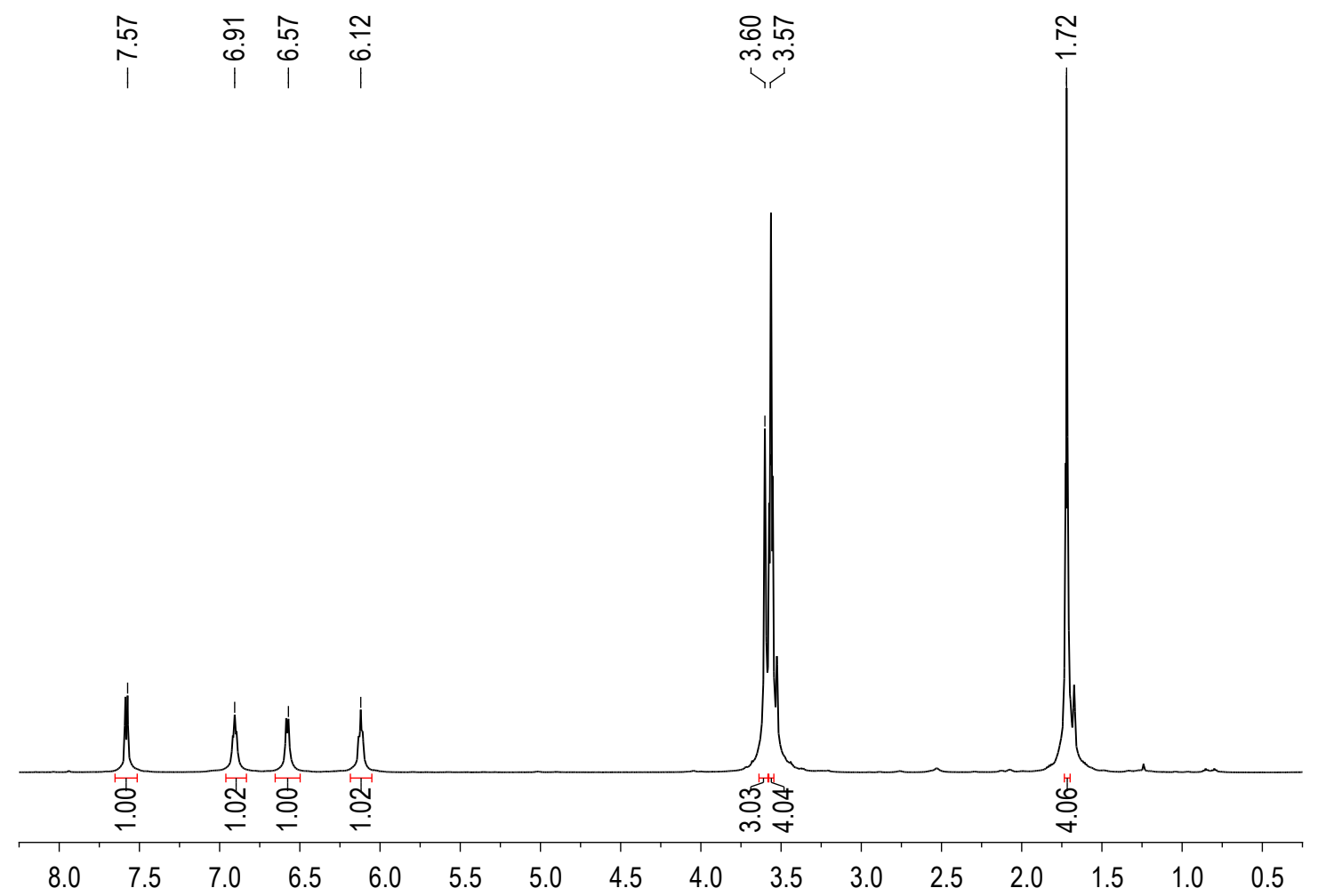

Figure S30. ${ }^{1} \mathrm{H}$ NMR spectrum of 9 in THF-D ${ }_{8}$.

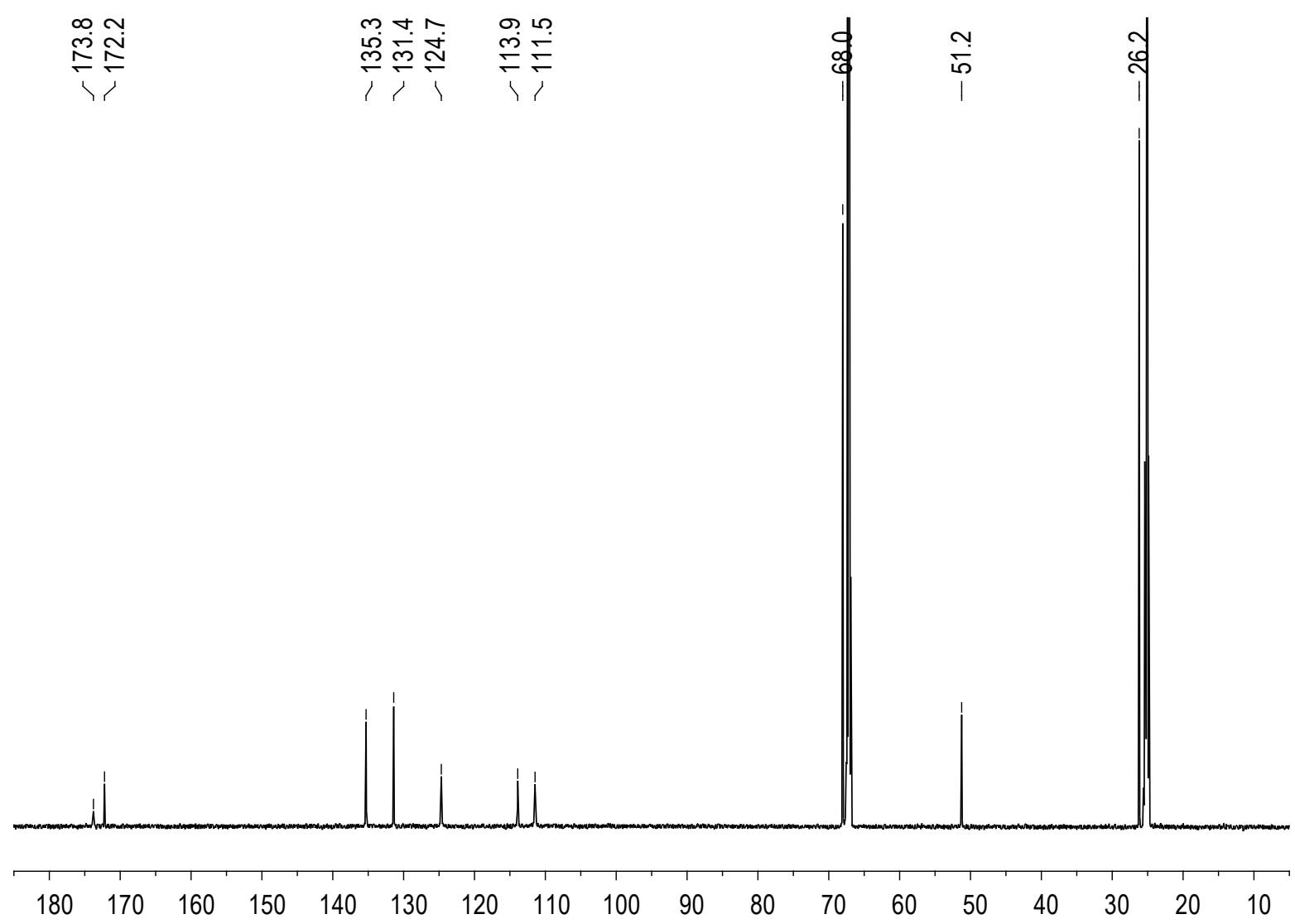

Figure S31. ${ }^{13} \mathrm{C}$ NMR spectrum of 9 in $\mathrm{THF}^{-\mathrm{D}_{8}}$. 


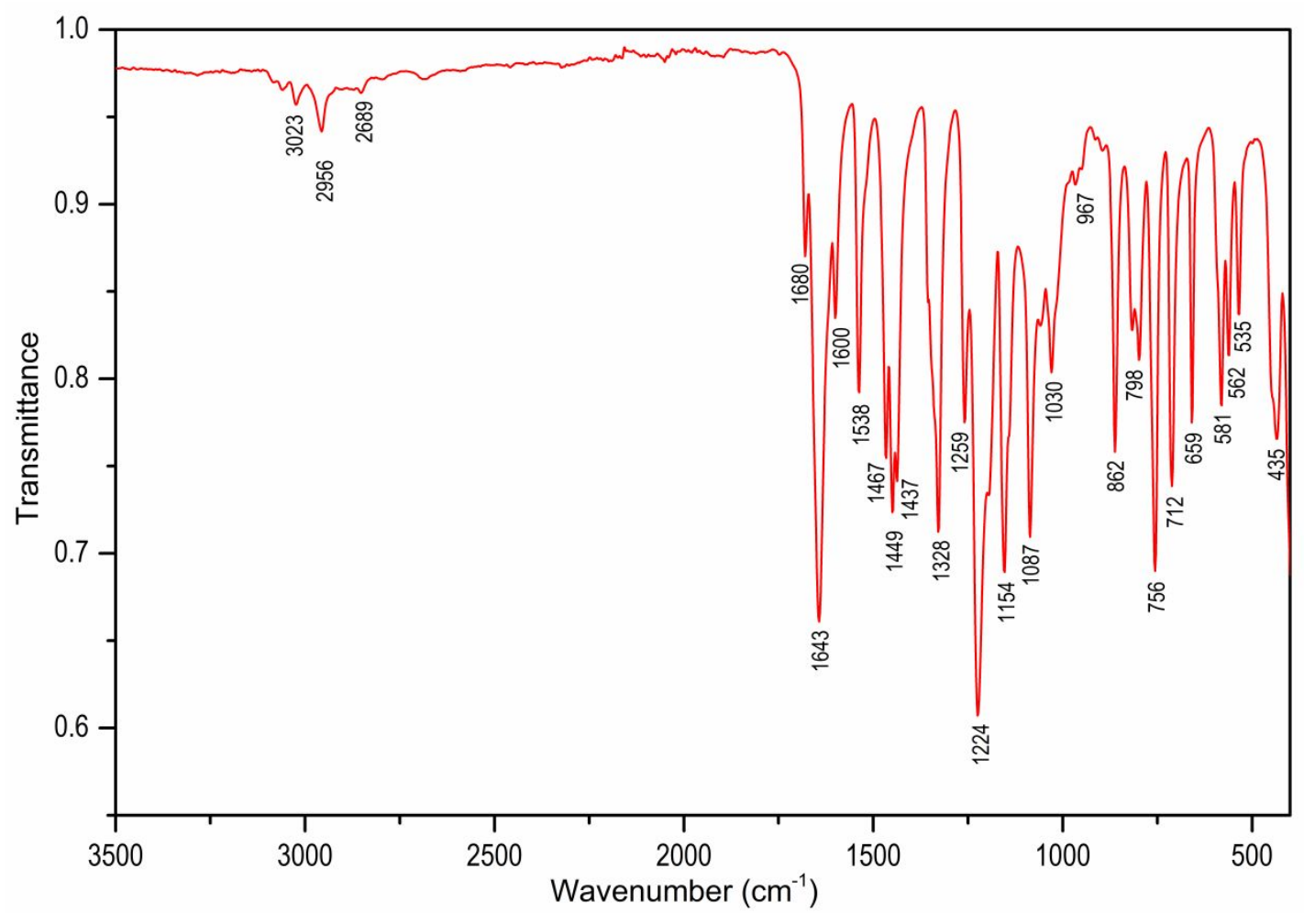

Figure S32. FTIR-ATR spectrum of 9.

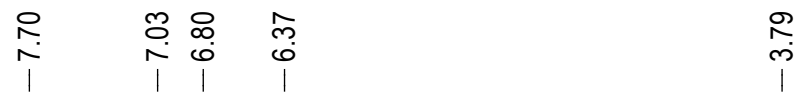

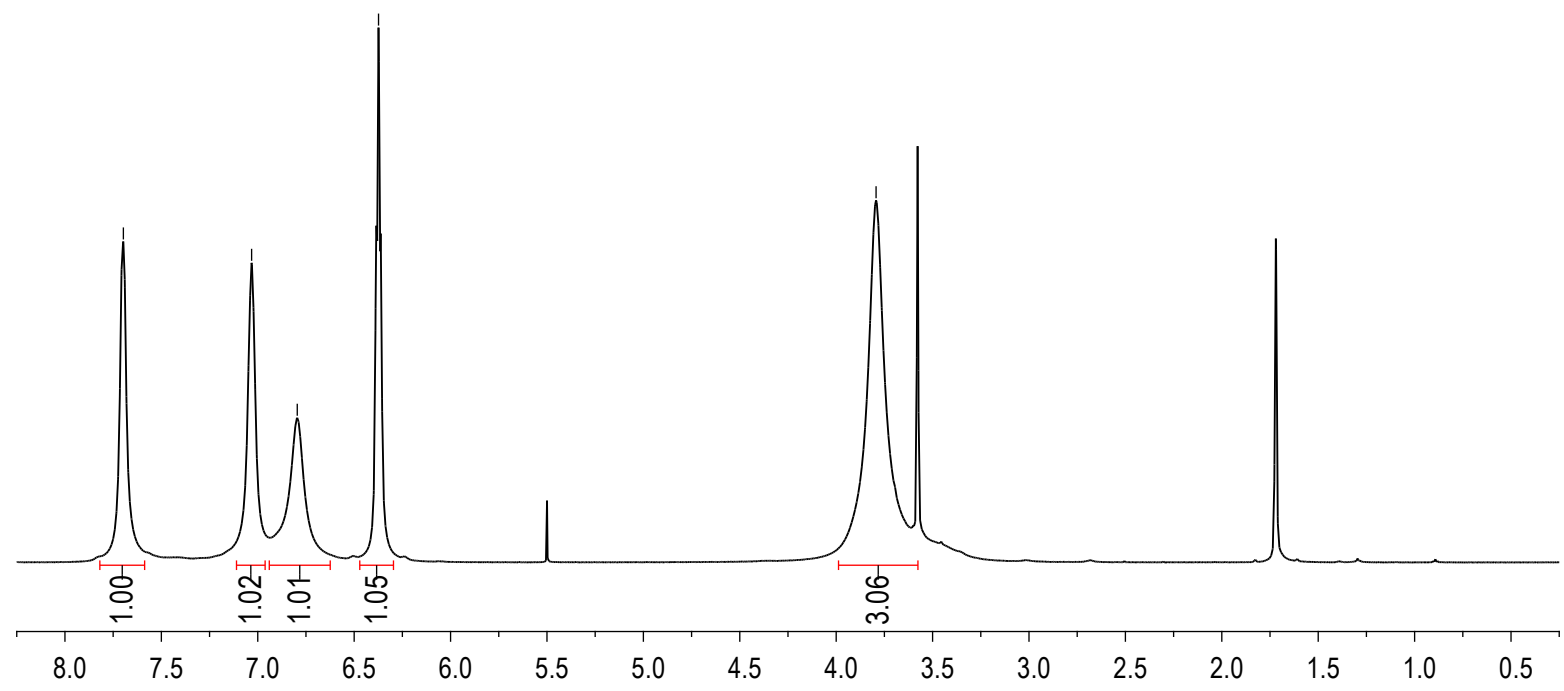

Figure S33. ${ }^{1} \mathrm{H}$ NMR spectrum of $\mathbf{1 0}$ in $\mathrm{THF}^{-\mathrm{D}_{8}}$. 


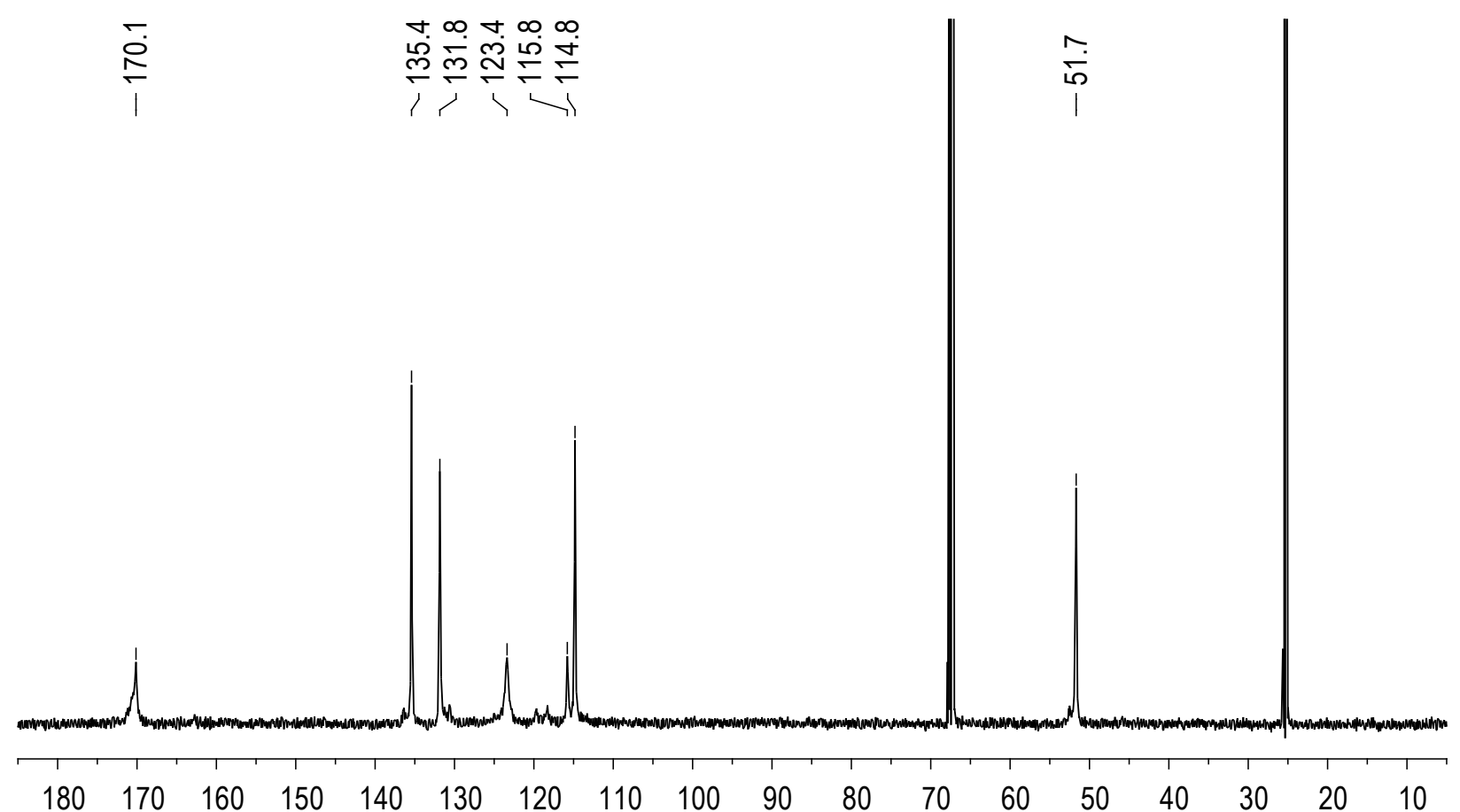

Figure S34. ${ }^{13} \mathrm{C}$ NMR spectrum of $\mathbf{1 0}$ in $\mathrm{THF}-\mathrm{D}_{8}$.

宛

m

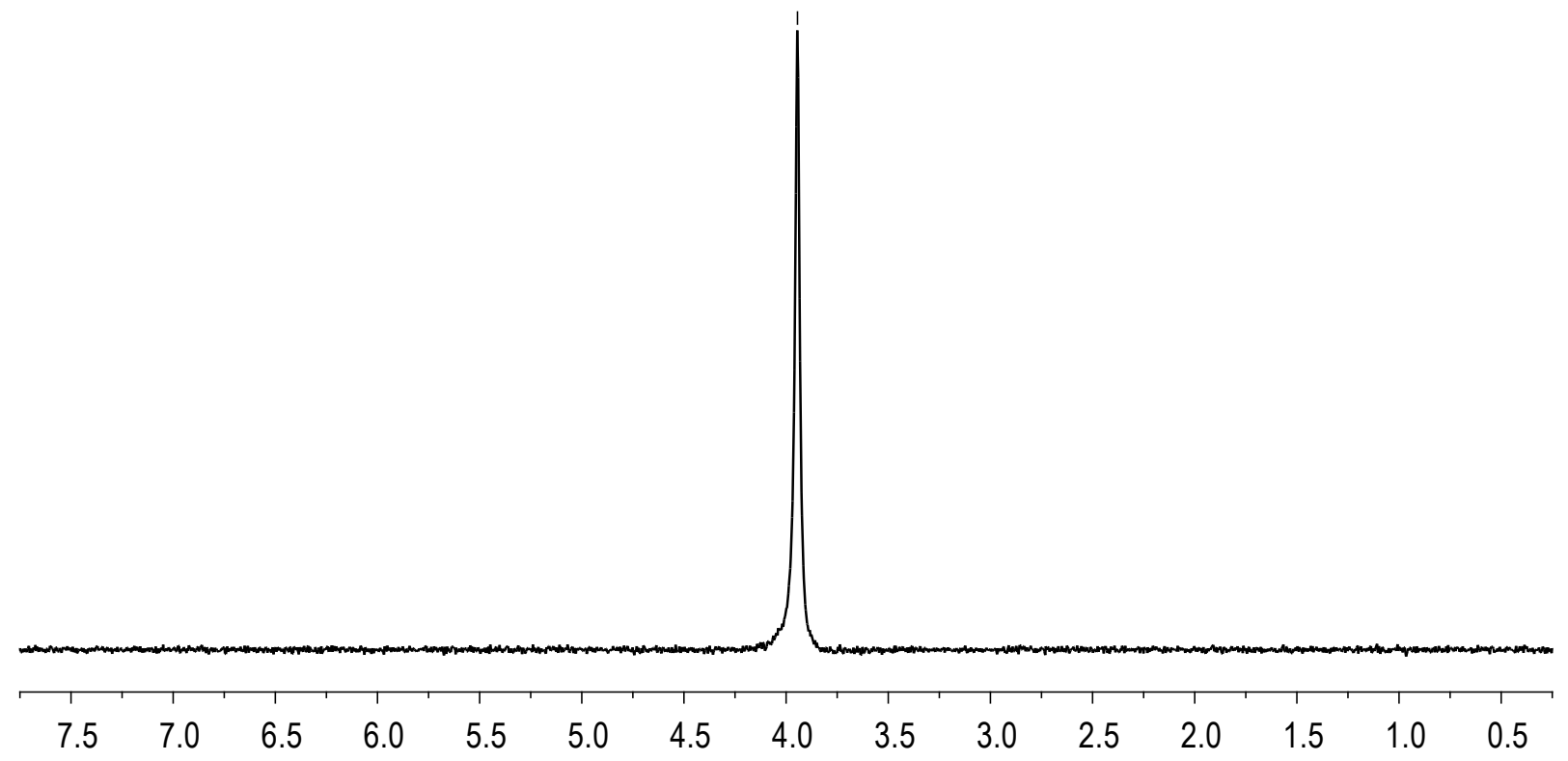

Figure S35. ${ }^{7} \mathrm{Li}$ NMR spectrum of $\mathbf{1 0}$ in $\mathrm{THF}^{-\mathrm{D}_{8}}$. 


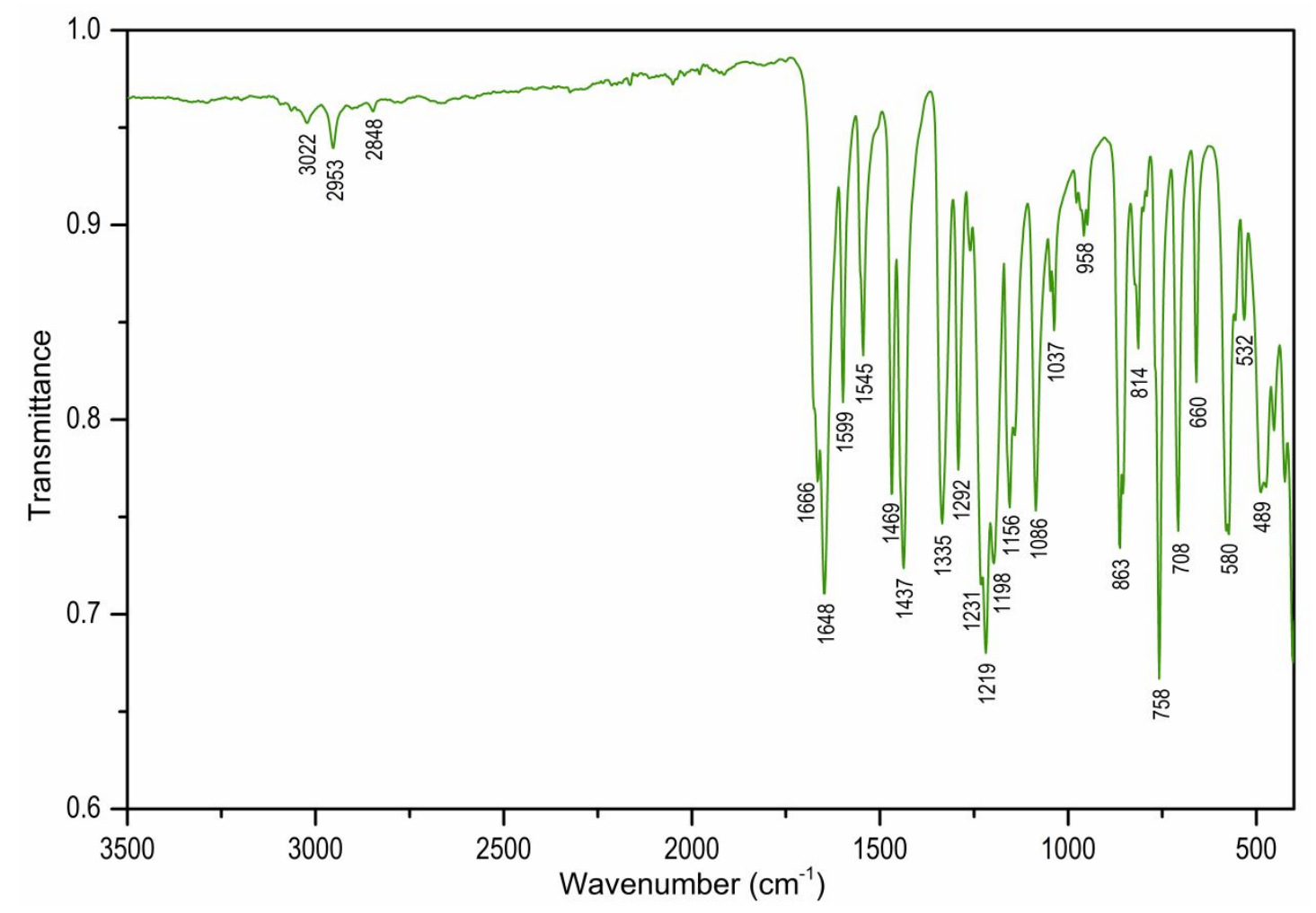

Figure S36. FTIR-ATR spectrum of $\mathbf{1 0 .}$

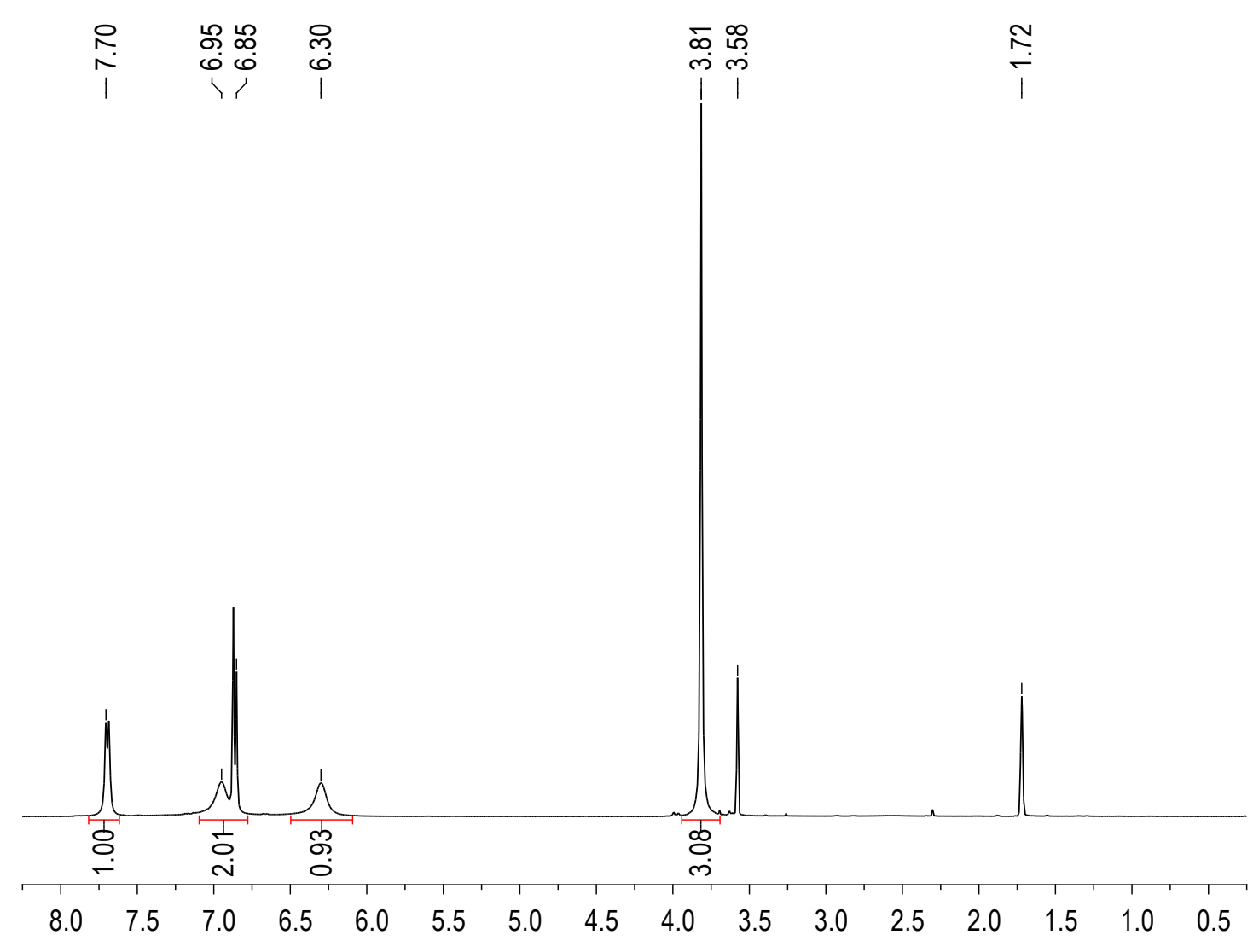

Figure S37. ${ }^{1} \mathrm{H}$ NMR spectrum of 11 in $\mathrm{THF}-\mathrm{D}_{8}$. 


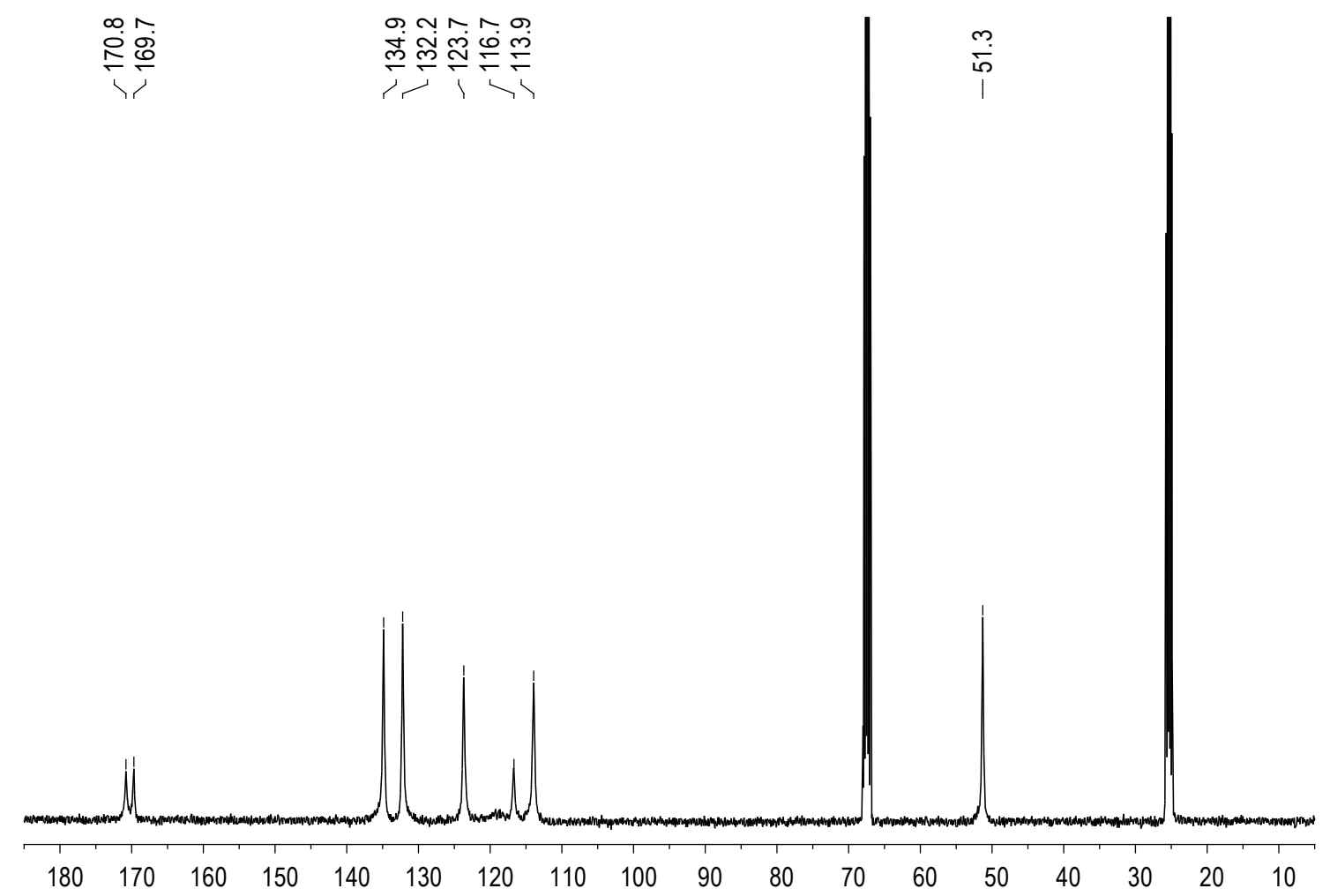

Figure S38. ${ }^{13} \mathrm{C}$ NMR spectrum of 11 in $\mathrm{THF}^{-\mathrm{D}_{8}}$.

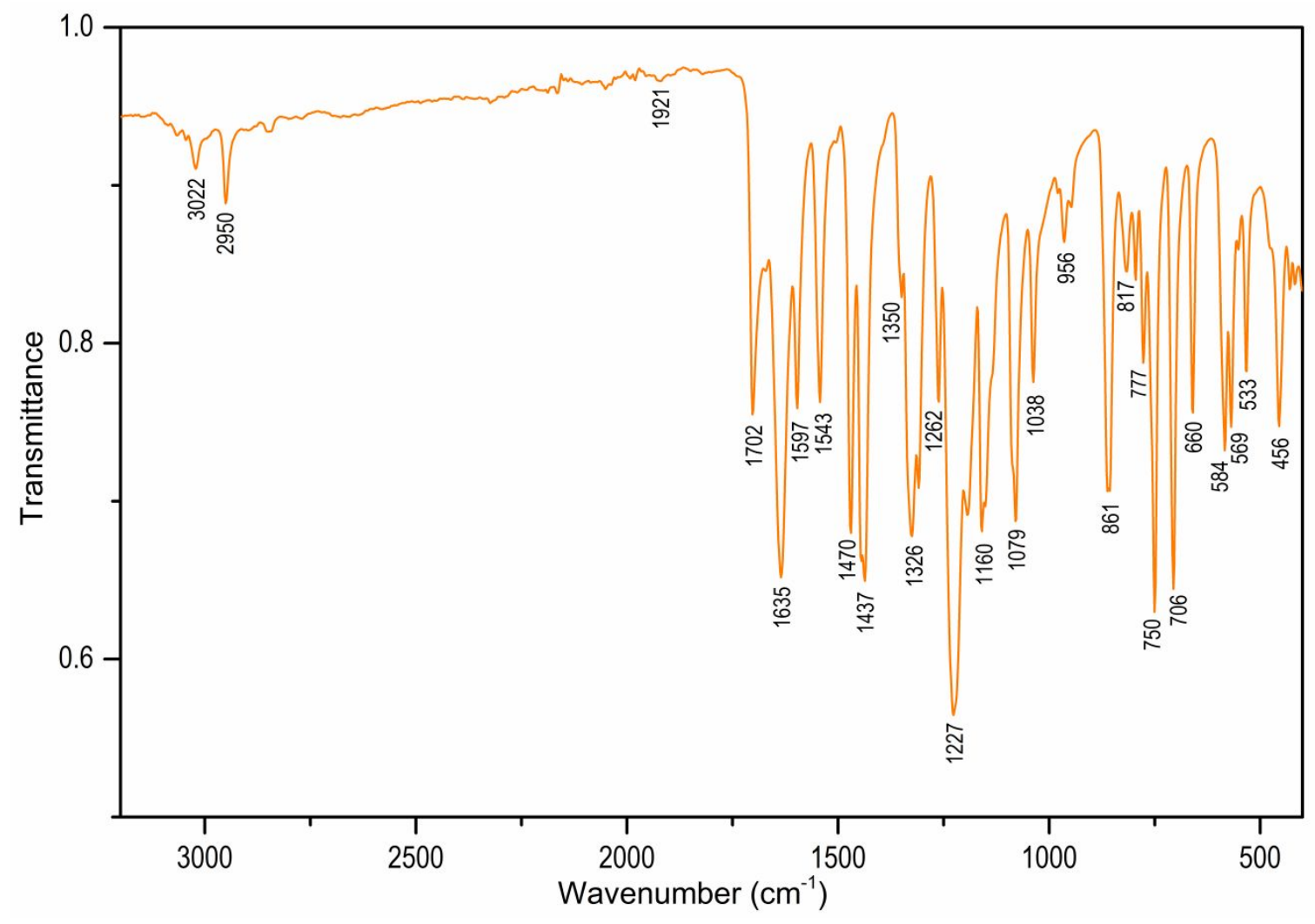

Figure S39. FTIR-ATR spectrum of 11. 


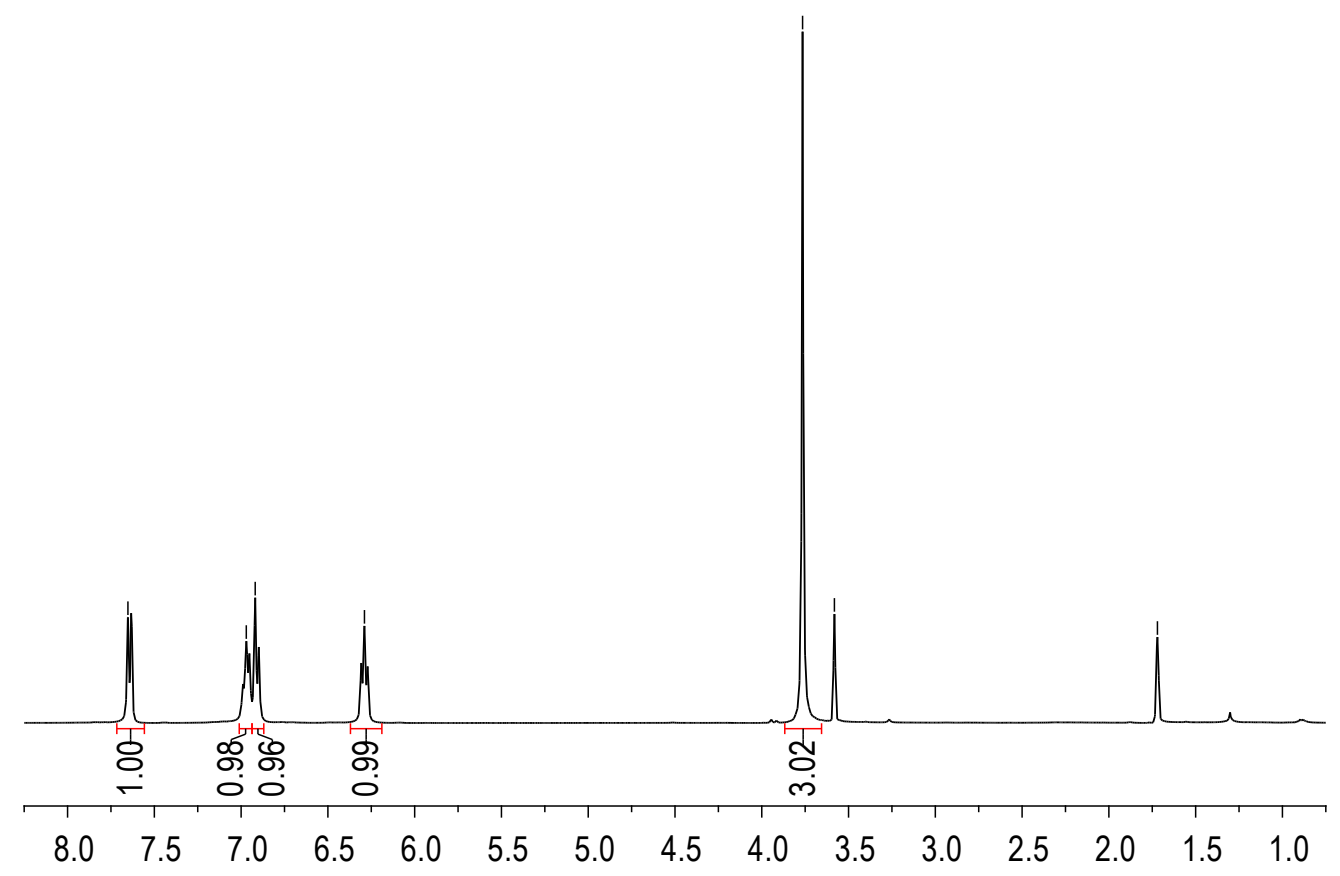

Figure S40. ${ }^{1} \mathrm{H}$ NMR spectrum of 12 in THF-D 8 .

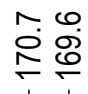

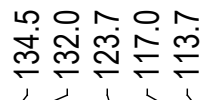

$\underset{\substack{0 \\ 1}}{\stackrel{1}{5}}$

$\stackrel{m}{\stackrel{m}{2}}$

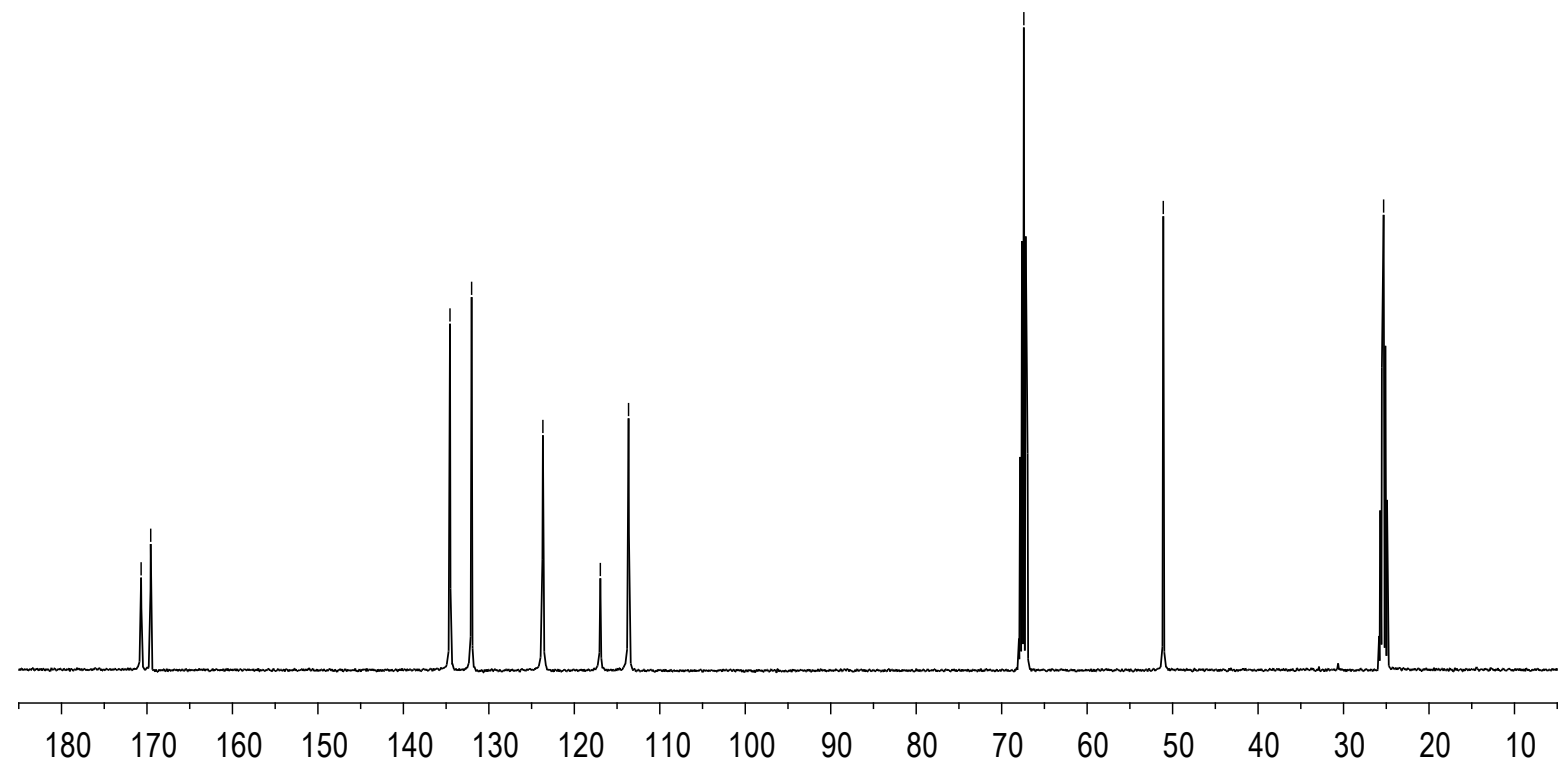

Figure S41. ${ }^{13} \mathrm{C}$ NMR spectrum of 12 in THF-D 8 . 


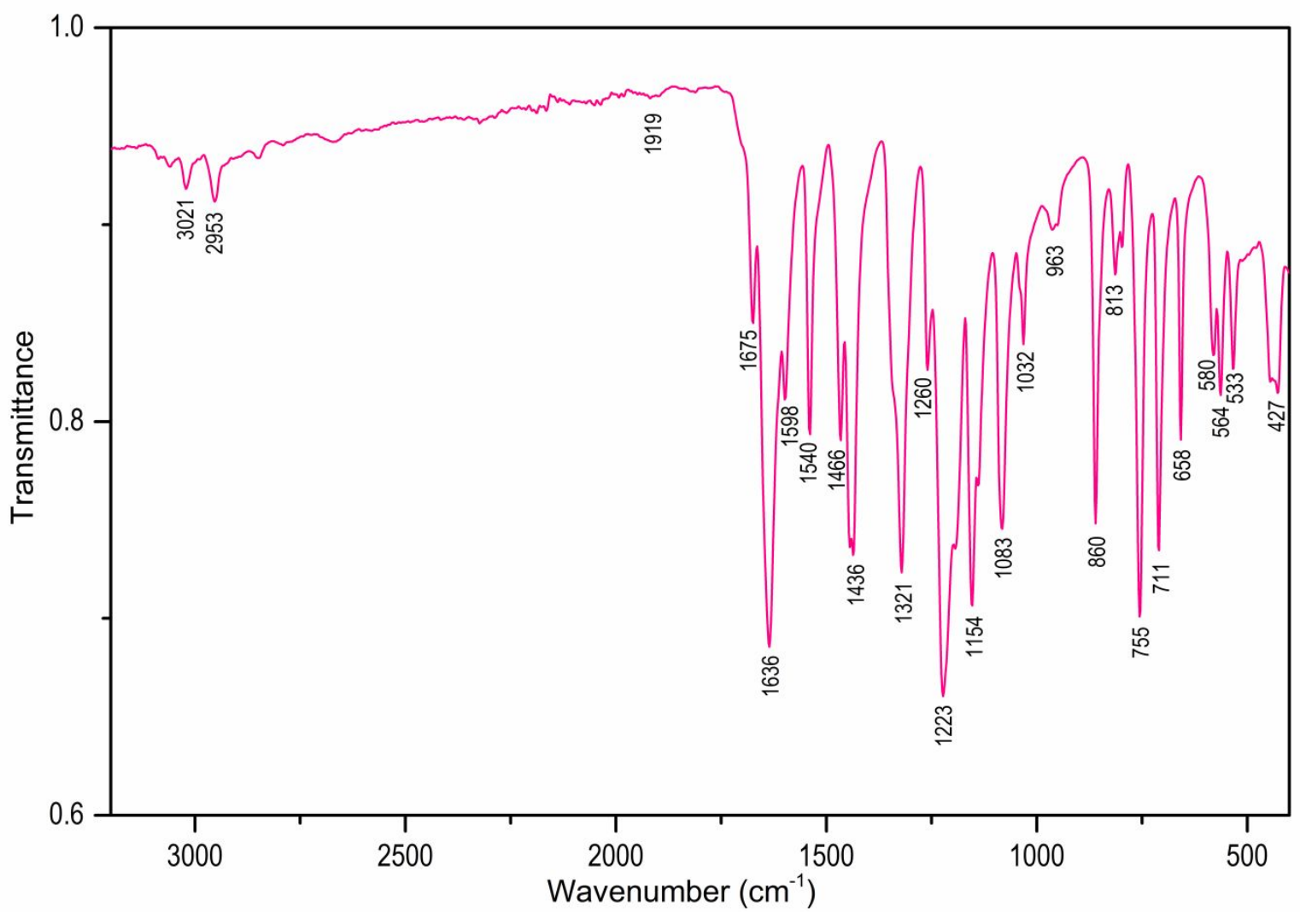

Figure S42. FTIR-ATR spectrum of 12.

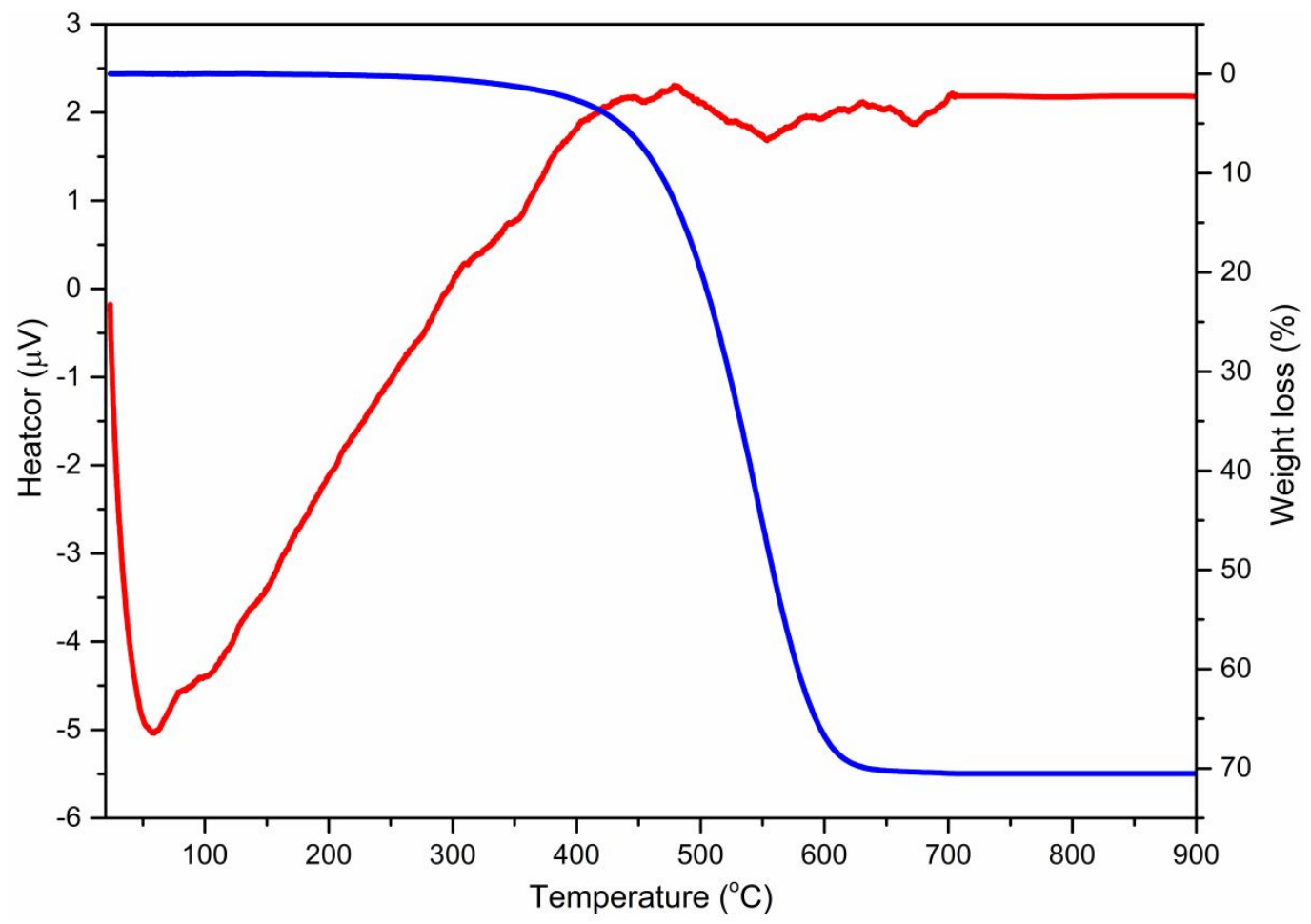

Figure S43. TGA-DTA thermograms of SR. 


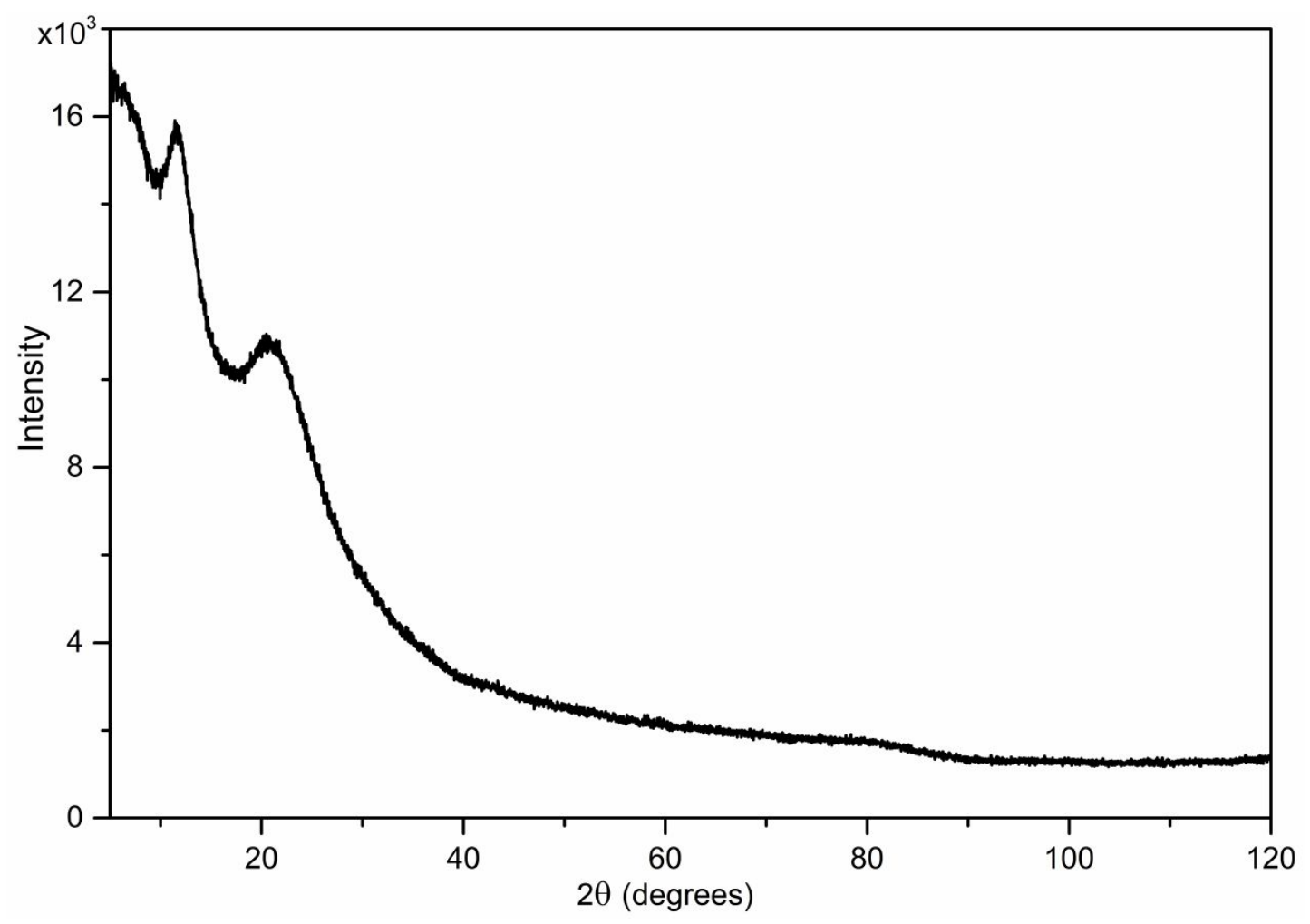

Figure S44. PXRD pattern of solid residues from SR alcoholysis reaction.

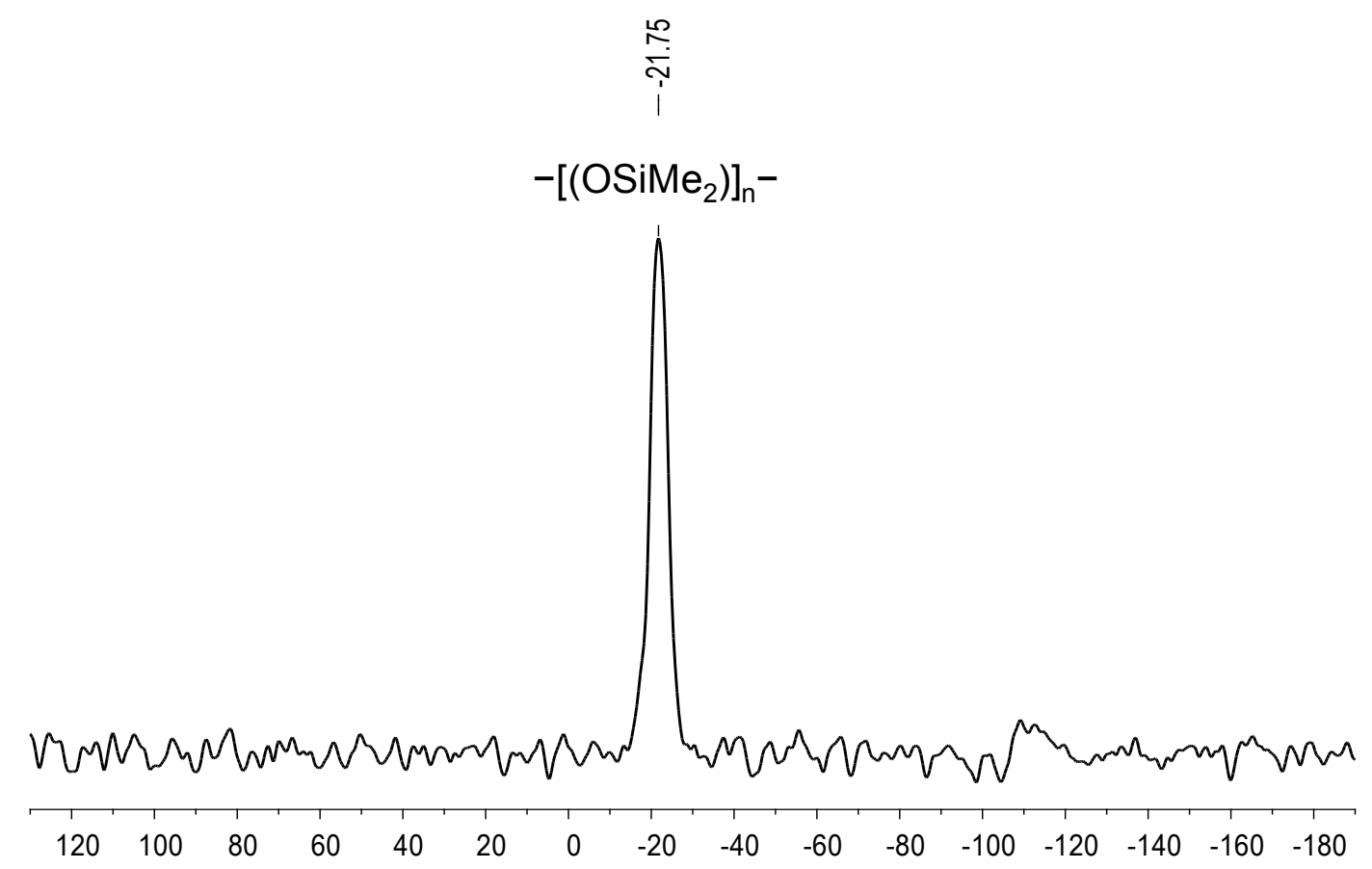

Figure S45. Solid-state ${ }^{29}$ Si NMR spectrum of SR residues after alcoholysis reaction. 
Table S3. Catalyst free solvothermal alcoholysis of high consistency SR. ${ }^{\mathrm{a}}$

\begin{tabular}{|c|c|c|c|c|c|c|c|c|}
\hline No. & $\mathbf{T}\left(\mathbf{~}^{\mathbf{C}}\right)$ & $\left.\mathbf{( O S i M e}_{\mathbf{2}}\right) / \mathbf{R O H}$ & $\mathbf{t}(\mathbf{h})$ & $\mathbf{P}_{\mathbf{1}}(\mathbf{\%})^{\mathrm{b}}$ & $\mathbf{P}_{\mathbf{2}}(\%)^{\mathrm{b}}$ & $\mathbf{P}_{\mathbf{3}}(\%)^{\mathrm{b}}$ & $\mathbf{P}_{\mathbf{4}}(\%)^{\mathrm{b}}$ & $\mathbf{P}_{\mathbf{m}} \mathbf{( \% ) ^ { \mathrm { b } }}$ \\
\hline 1. & 180 & $1 / 2$ & 16 & -- & -- & -- & -- & 22 \\
2. & 180 & $1 / 4$ & 16 & -- & -- & -- & -- & 27 \\
3. & 180 & $1 / 6$ & 16 & -- & -- & -- & -- & 33 \\
4. & 180 & $1 / 8$ & 16 & -- & -- & -- & -- & 41 \\
\hline 5. & 200 & $1 / 2$ & 18 & -- & -- & -- & -- & 69 \\
6. & 200 & $1 / 4$ & 18 & -- & -- & -- & -- & 70 \\
7. & 200 & $1 / 6$ & 18 & -- & -- & -- & -- & 78 \\
8. & 200 & $1 / 8$ & 18 & -- & -- & -- & -- & 80 \\
\hline 9. & 220 & $1 / 2$ & 18 & 18 & 5 & 4 & 5 & 68 \\
10. & 220 & $1 / 4$ & 18 & 20 & 5 & 5 & 5 & 65 \\
11. & 220 & $1 / 6$ & 18 & 22 & 4 & 4 & 4 & 66 \\
12. & 220 & $1 / 8$ & 18 & 24 & 5 & 5 & 5 & 61 \\
\hline 13. & 240 & $1 / 2$ & 18 & 15 & 9 & 8 & 6 & 61 \\
14. & 240 & $1 / 4$ & 18 & 18 & 9 & 8 & 7 & 58 \\
15. & 240 & $1 / 6$ & 18 & 22 & 10 & 9 & 8 & 51 \\
16. & 240 & $1 / 8$ & 18 & 24 & 11 & 10 & 8 & 47 \\
\hline
\end{tabular}

${ }^{a}$ Alcoholysis conditions: 0.5g of SR (ELASTOSIL ${ }^{\circledR} \mathrm{R} 401 / 60 \mathrm{~S}$, Wacker Chemie AG) and from 2.2 to $8.6 \mathrm{~mL}$ of n-octanol. Reaction performed using pressure reactor with a capacity of $25 \mathrm{~mL}$, under autogenous pressure of reactants, through 16-18h. ${ }^{b}$ Determined by GC-MS and corrected by the amount of isolated unreacted solid material.

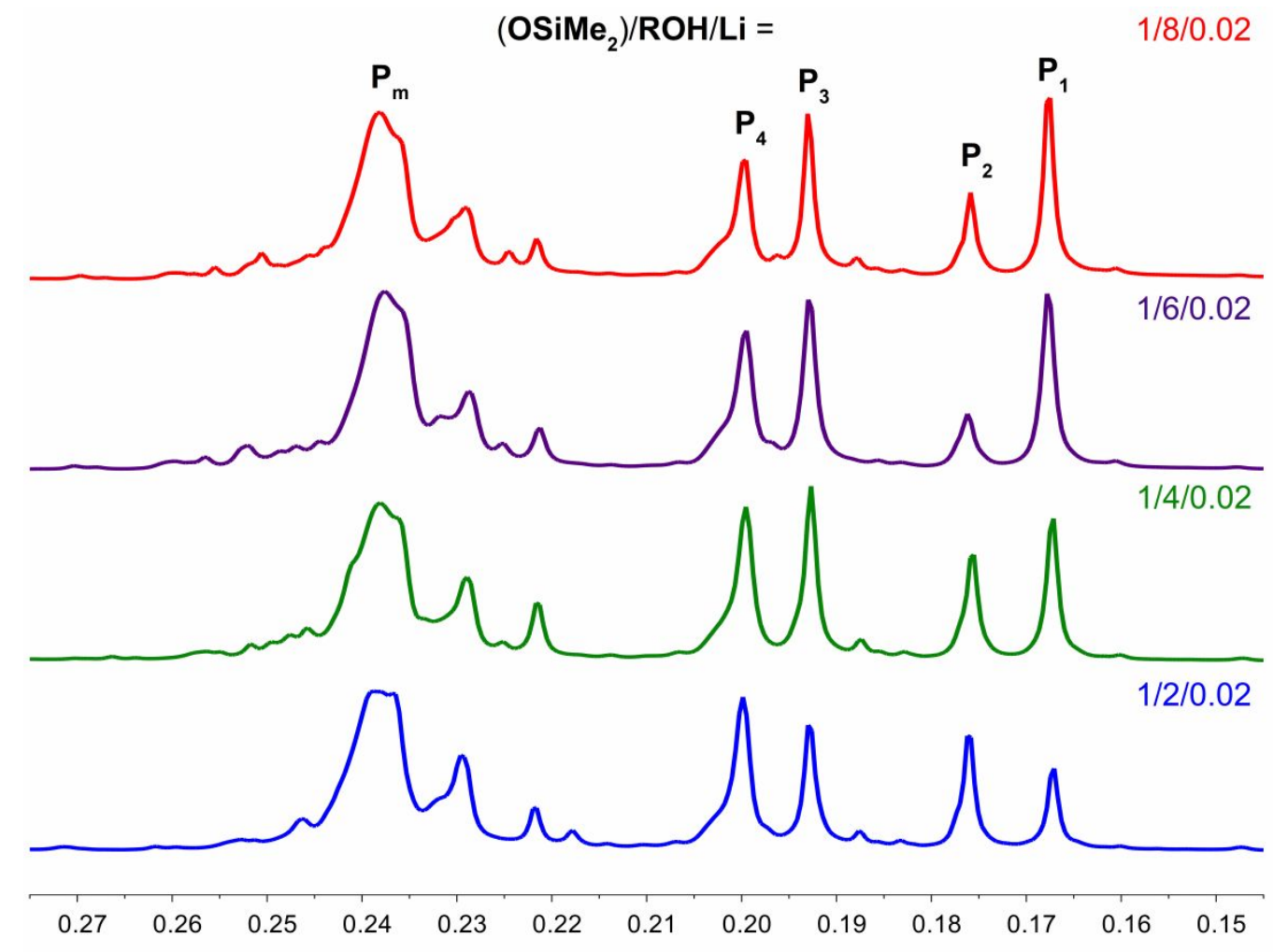

Figure S46. ${ }^{1} \mathrm{H}$ NMR spectra in the Si-Me region of liquid samples formed in the SR alcoholysis reaction at $200{ }^{\circ} \mathrm{C}$ using from 2 to 8 molar equiv of $\mathrm{ROH}$ and $0.33 \mathrm{~mol} \%$ of 4 . 


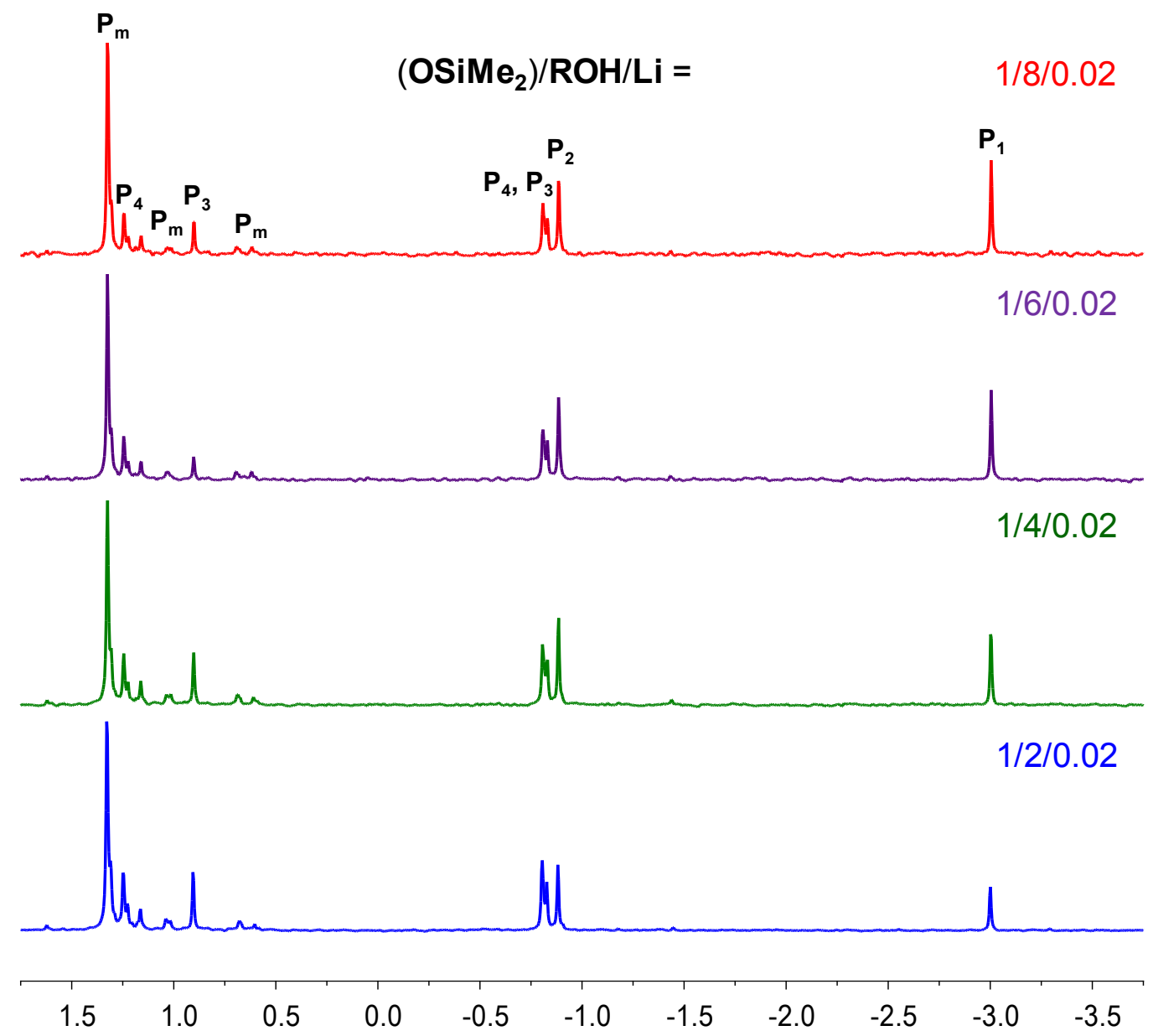

Figure S47. ${ }^{13} \mathrm{C}$ NMR spectra in the Si-Me region of liquid samples formed in the SR alcoholysis reaction at $200{ }^{\circ} \mathrm{C}$ using from 2 to 8 molar equiv of $\mathrm{ROH}$ and $0.33 \mathrm{~mol} \%$ of 4 . 
Table S4. Catalytic solvothermal alcoholysis of high consistency SR. ${ }^{\mathrm{a}}$

\begin{tabular}{|c|c|c|c|c|c|c|c|}
\hline No. & Initiator & $\left(\mathbf{O S i M e}_{\mathbf{2}}\right) \mathbf{R O H}$ & $\mathbf{P}_{\mathbf{1}}(\mathbf{\%})$ & $\mathbf{P}_{\mathbf{2}}(\mathbf{\%})$ & $\mathbf{P}_{\mathbf{3}}(\mathbf{\%})$ & $\mathbf{P}_{\mathbf{4}}(\mathbf{\%})$ & $\mathbf{P}_{\mathbf{m}} \mathbf{( \% )}$ \\
\hline 1. & $\mathbf{2}$ & $1 / 2$ & 20 & 6 & 1 & $<1$ & $<1$ \\
2. & $\mathbf{2}$ & $1 / 4$ & 23 & 4 & $<1$ & $<1$ & $<1$ \\
3. & $\mathbf{2}$ & $1 / 6$ & 36 & $<1$ & $<1$ & $<1$ & $<1$ \\
4. & $\mathbf{2}$ & $1 / 8$ & 38 & $<1$ & $<1$ & $<1$ & $<1$ \\
\hline 5. & $\mathbf{3}$ & $1 / 2$ & 46 & 1 & $<1$ & $<1$ & 2 \\
6. & $\mathbf{3}$ & $1 / 4$ & 46 & $<1$ & $<1$ & $<1$ & 2 \\
7. & $\mathbf{3}$ & $1 / 6$ & 49 & $<1$ & $<1$ & $<1$ & $<1$ \\
8. & $\mathbf{3}$ & $1 / 8$ & 50 & $<1$ & $<1$ & $<1$ & $<1$ \\
\hline 9. & $\mathbf{4}$ & $1 / 2$ & 38 & 25 & 13 & 7 & 17 \\
10. & $\mathbf{4}$ & $1 / 4$ & 47 & 24 & 11 & 5 & 13 \\
11. & $\mathbf{4}$ & $1 / 6$ & 52 & 22 & 10 & 5 & 11 \\
12. & $\mathbf{4}$ & $1 / 8$ & 57 & 21 & 8 & 4 & 10 \\
\hline 13. & $\mathbf{5}$ & $1 / 2$ & 45 & 26 & 12 & 8 & 9 \\
14. & $\mathbf{5}$ & $1 / 4$ & 51 & 24 & 10 & 6 & 9 \\
15. & $\mathbf{5}$ & $1 / 6$ & 52 & 20 & 8 & 5 & 6 \\
16. & $\mathbf{5}$ & $1 / 8$ & 55 & 20 & 8 & 6 & 6 \\
\hline 17. & $\mathbf{6}$ & $1 / 2$ & 40 & 23 & 18 & 6 & 13 \\
18. & $\mathbf{6}$ & $1 / 4$ & 56 & 25 & 8 & 3 & 7 \\
19. & $\mathbf{6}$ & $1 / 6$ & 66 & 20 & 6 & 3 & 5 \\
20. & $\mathbf{6}$ & $1 / 8$ & 68 & 19 & 5 & 3 & 5 \\
\hline
\end{tabular}

${ }^{a}$ Alcoholysis conditions: $0.5 \mathrm{~g}$ of SR (ELASTOSIL ${ }^{\circledR} \mathrm{R} 401 / 60 \mathrm{~S}$, Wacker Chemie AG) and from 2.2 to $8.6 \mathrm{~mL}$ of n-octanol. Reaction performed using pressure reactor with a capacity of $25 \mathrm{~mL}$, with stoichiometry $\left(\mathrm{OSiMe}_{2}\right) / \mathrm{ROH} / \mathrm{M}=1 /(2-8) / 0.02$, under autogenous pressure of reactants, through $2 \mathrm{~h}$ at $220{ }^{\circ} \mathrm{C} .{ }^{b}$ Determined by GC-MS and corrected by the amount of isolated unreacted solid material.

Table S5. Catalytic solvothermal alcoholysis of high consistency SR. ${ }^{a}$

\begin{tabular}{|c|c|c|c|c|c|c|c|}
\hline No. & Catalyst & $\mathbf{~ O S i M e ~}) / \mathbf{R O H}$ & $\mathbf{P}_{\mathbf{1}}(\%)$ & $\mathbf{P}_{\mathbf{2}}(\%)$ & $\mathbf{P}_{\mathbf{3}}(\%)$ & $\mathbf{P}_{\mathbf{4}}(\%)$ & $\mathbf{P}_{\mathbf{m}} \mathbf{( \% )}$ \\
\hline 1. & $\mathbf{2}$ & $1 / 2$ & 26 & 11 & 1 & $<1$ & 2 \\
2. & $\mathbf{2}$ & $1 / 4$ & 27 & 13 & $<1$ & $<1$ & $<1$ \\
3. & $\mathbf{2}$ & $1 / 6$ & 27 & 11 & $<1$ & $<1$ & $<1$ \\
4. & $\mathbf{2}$ & $1 / 8$ & 28 & 9 & $<1$ & $<1$ & $<1$ \\
\hline 5. & $\mathbf{3}$ & $1 / 2$ & 29 & 1 & $<1$ & $<1$ & $<1$ \\
6. & $\mathbf{3}$ & $1 / 4$ & 32 & $<1$ & $<1$ & $<1$ & $<1$ \\
7. & $\mathbf{3}$ & $1 / 6$ & 32 & $<1$ & $<1$ & $<1$ & $<1$ \\
8. & $\mathbf{3}$ & $1 / 8$ & 33 & $<1$ & $<1$ & $<1$ & $<1$ \\
\hline 9. & $\mathbf{4}$ & $1 / 2$ & 36 & 26 & 13 & 8 & 17 \\
10. & $\mathbf{4}$ & $1 / 4$ & 46 & 24 & 11 & 6 & 13 \\
11. & $\mathbf{4}$ & $1 / 6$ & 51 & 23 & 9 & 5 & 12 \\
12. & $\mathbf{4}$ & $1 / 8$ & 56 & 21 & 9 & 4 & 10 \\
\hline 13. & $\mathbf{5}$ & $1 / 2$ & 43 & 27 & 13 & 7 & 10 \\
14. & $\mathbf{5}$ & $1 / 4$ & 52 & 23 & 10 & 6 & 9 \\
15. & $\mathbf{5}$ & $1 / 6$ & 53 & 23 & 9 & 6 & 9 \\
16. & $\mathbf{5}$ & $1 / 8$ & 53 & 23 & 9 & 6 & 9 \\
\hline 17. & $\mathbf{6}$ & $1 / 2$ & 44 & 18 & 4 & 2 & 3 \\
18. & $\mathbf{6}$ & $1 / 4$ & 58 & 6 & 3 & 2 & 4 \\
19. & $\mathbf{6}$ & $1 / 6$ & 68 & 5 & 4 & 2 & 4 \\
20. & $\mathbf{6}$ & $1 / 8$ & 70 & 4 & 3 & 2 & 2 \\
\hline
\end{tabular}

${ }^{a}$ Alcoholysis conditions: 0.5g of SR (ELASTOSIL ${ }^{\circledR} \mathrm{R} 401 / 60 \mathrm{~S}$, Wacker Chemie AG) and from 2.2 to $8.6 \mathrm{~mL}$ of n-octanol. Reaction performed using pressure reactor with a capacity of $25 \mathrm{~mL}$, with stoichiometry $\left(\mathrm{OSiMe}_{2}\right) / \mathrm{ROH} / \mathrm{M}=1 /(2-8) / 0.04$, under autogenous pressure of reactants, through $2 \mathrm{~h}$ at $220^{\circ} \mathrm{C} .{ }^{b}$ Determined by $\mathrm{GC}-\mathrm{MS}$ and corrected by the amount of isolated unreacted solid material. 
Table S6. Catalytic solvothermal alcoholysis of high consistency SR in the presence of $\left[\mathrm{M}_{2} \mathrm{M}_{2}{ }_{2}(\mathrm{MesalO})_{6}\right]$ where $\mathrm{M}=\mathrm{Mg}$ or $\mathrm{Zn}$ and $\mathrm{M}^{\prime}=\mathrm{Li}, \mathrm{Na}, \mathrm{K}{ }^{\mathrm{a}}$

\begin{tabular}{|c|c|c|c|c|c|c|c|}
\hline No. & Initiator & $\left.\mathbf{( O S i M e}_{\mathbf{2}}\right) \mathbf{R O H}$ & $\mathbf{P}_{\mathbf{1}}(\mathbf{\%})$ & $\mathbf{P}_{\mathbf{2}}(\%)$ & $\mathbf{P}_{\mathbf{3}}(\%)$ & $\mathbf{P}_{\mathbf{4}}(\mathbf{\%})$ & $\mathbf{P}_{\mathbf{m}}(\mathbf{\%})$ \\
\hline 1. & $\mathbf{7}$ & $1 / 2$ & 62 & 20 & 9 & 4 & 5 \\
2. & $\mathbf{7}$ & $1 / 4$ & 69 & 16 & 7 & 3 & 5 \\
3. & $\mathbf{7}$ & $1 / 6$ & 71 & 15 & 6 & 3 & 5 \\
4. & $\mathbf{7}$ & $1 / 8$ & 72 & 16 & 5 & 3 & 4 \\
\hline 5. & $\mathbf{8}$ & $1 / 2$ & 72 & 20 & 3 & 2 & 3 \\
6. & $\mathbf{8}$ & $1 / 4$ & 76 & 19 & 2 & 1 & 2 \\
7. & $\mathbf{8}$ & $1 / 6$ & 78 & 18 & 2 & 1 & 1 \\
8. & $\mathbf{8}$ & $1 / 8$ & 78 & 17 & 2 & 1 & 2 \\
\hline 9. & $\mathbf{9}$ & $1 / 2$ & 74 & 19 & 2 & 1 & 4 \\
10. & $\mathbf{9}$ & $1 / 4$ & 77 & 19 & 1 & 1 & 2 \\
11. & $\mathbf{9}$ & $1 / 6$ & 77 & 19 & 1 & $<1$ & 2 \\
12. & $\mathbf{9}$ & $1 / 8$ & 79 & 19 & 1 & $<1$ & $<1$ \\
\hline 13. & $\mathbf{1 0}$ & $1 / 2$ & 58 & 27 & 6 & 2 & 7 \\
14. & $\mathbf{1 0}$ & $1 / 4$ & 64 & 24 & 5 & 2 & 5 \\
15. & $\mathbf{1 0}$ & $1 / 6$ & 65 & 23 & 5 & 2 & 5 \\
16. & $\mathbf{1 0}$ & $1 / 8$ & 68 & 21 & 4 & 2 & 5 \\
\hline 17. & $\mathbf{1 1}$ & $1 / 2$ & 43 & 15 & 4 & 2 & 3 \\
18. & $\mathbf{1 1}$ & $1 / 4$ & 49 & 15 & 4 & 2 & 3 \\
19. & $\mathbf{1 1}$ & $1 / 6$ & 51 & 14 & 4 & 2 & 3 \\
20. & $\mathbf{1 1}$ & $1 / 8$ & 53 & 14 & 4 & 2 & 2 \\
\hline 21. & $\mathbf{1 2}$ & $1 / 2$ & 26 & 5 & 1 & 1 & 2 \\
22. & $\mathbf{1 2}$ & $1 / 4$ & 33 & 6 & 1 & 1 & 2 \\
23. & $\mathbf{1 2}$ & $1 / 6$ & 35 & 7 & 1 & $<1$ & 1 \\
24. & $\mathbf{1 2}$ & $1 / 8$ & 38 & 7 & 1 & $<1$ & 1 \\
\hline 25. & $\mathbf{1 3}$ & $1 / 2$ & 60 & 26 & 7 & 2 & 5 \\
26. & $\mathbf{1 3}$ & $1 / 4$ & 65 & 23 & 5 & 2 & 5 \\
\hline
\end{tabular}

${ }^{a}$ Alcoholysis conditions: $0.5 \mathrm{~g}$ of SR (ELASTOSIL ${ }^{\circledR} \mathrm{R} 401 / 60 \mathrm{~S}$, Wacker Chemie AG) and from 2.2 to $8.6 \mathrm{~mL}$ of n-octanol. Reaction performed using pressure reactor with a capacity of $25 \mathrm{~mL}$, with stoichiometry $\left(\mathrm{OSiMe}_{2}\right) / \mathrm{ROH} /\left[\mathrm{M}_{2} \mathrm{M}_{2}{ }_{2}(\mathrm{MesalO})_{6}\right]=1 /(2-8) / 0.01$, under autogenous pressure of reactants, through $2 \mathrm{~h}$ at $220{ }^{\circ} \mathrm{C}$. ${ }^{b}$ Determined by GC-MS and corrected by the amount of isolated unreacted solid material.

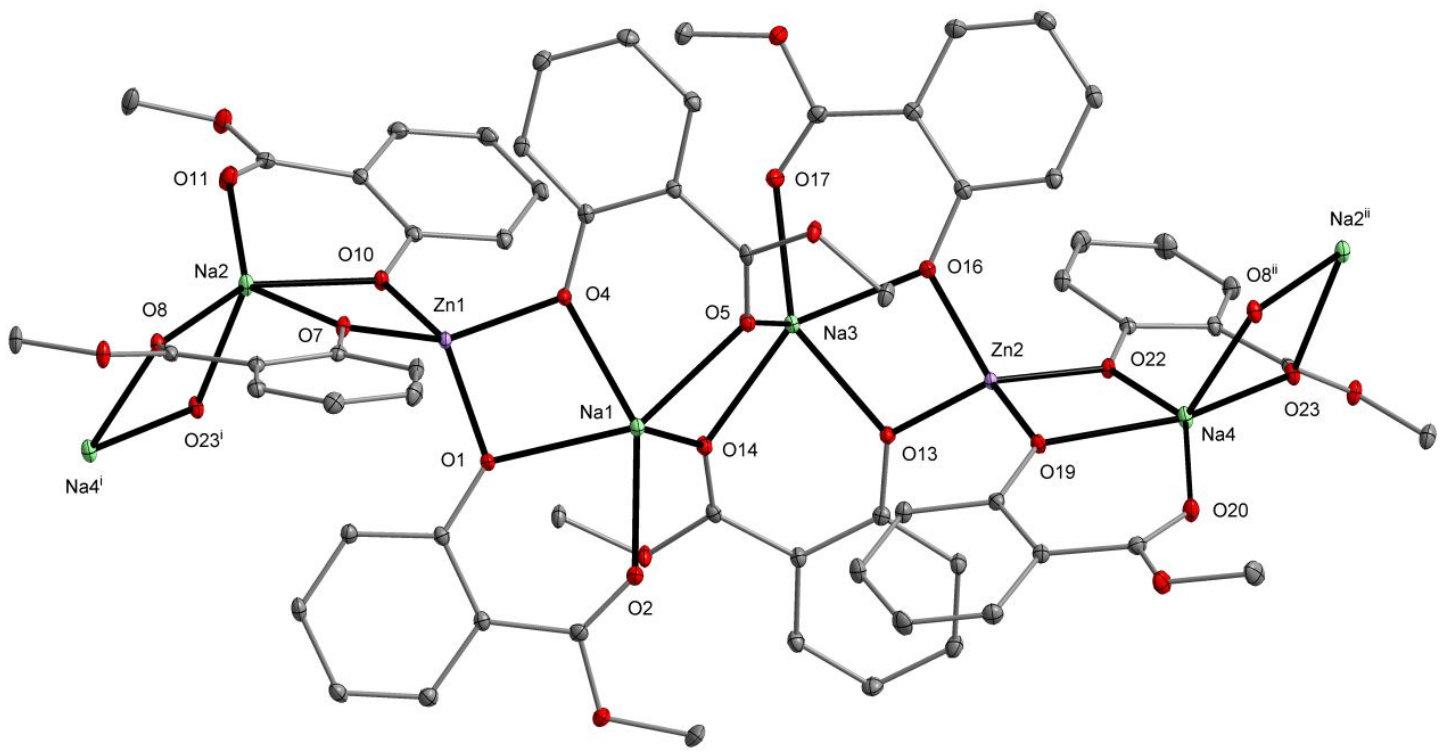

Figure S48. Molecular structures of $\left[\mathrm{Zn}_{2} \mathrm{Na}_{4}(\mathrm{MesalO})_{8}\right]_{\mathrm{n}}$ (13) with displacement ellipsoids drawn at the $25 \%$ probability level. The hydrogen atoms are omitted for clarity [symmetry code: (i) $\mathrm{x}+1, \mathrm{y}, \mathrm{z}$; (ii) $\mathrm{x}-1, \mathrm{y}, \mathrm{z}$. 


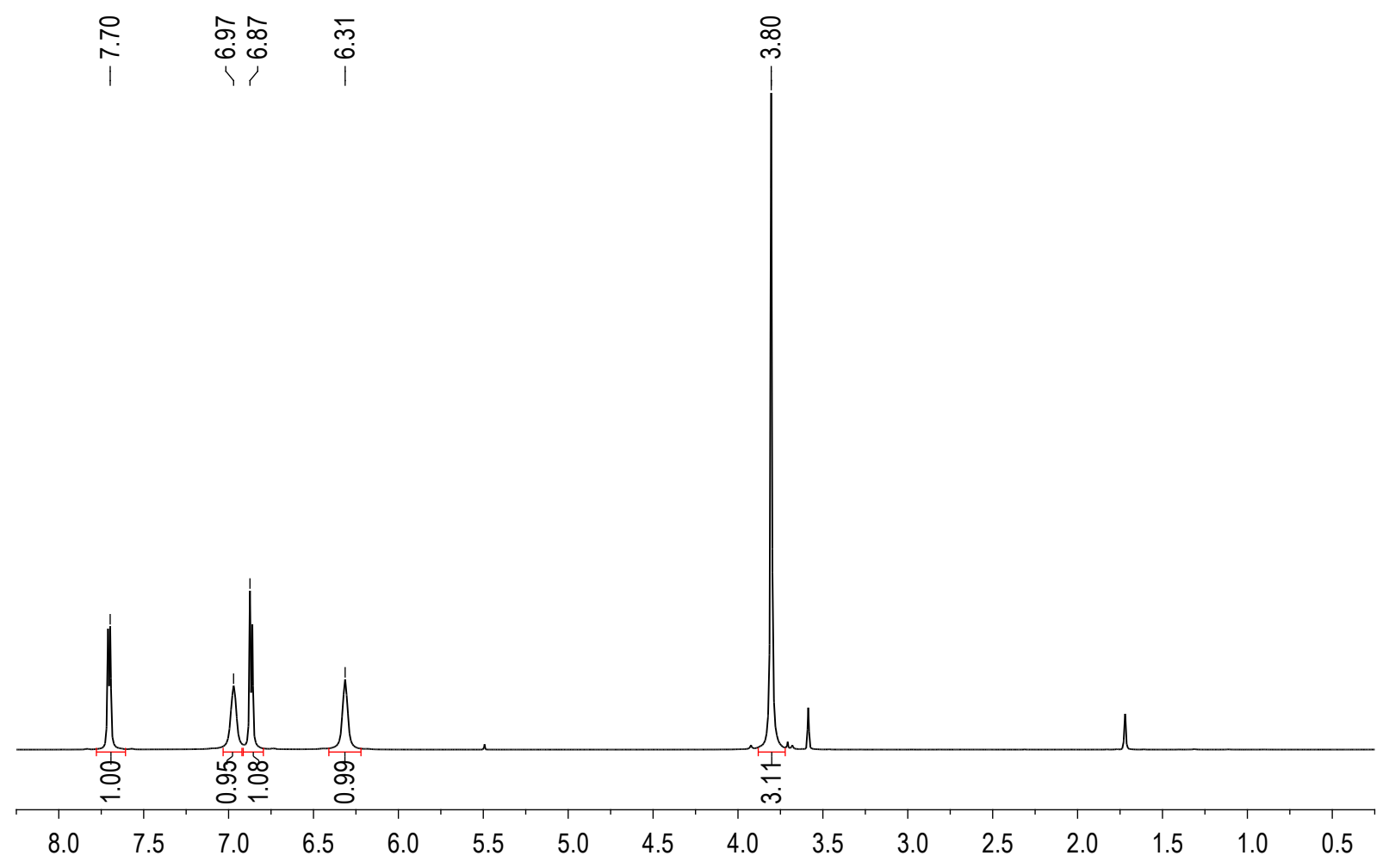

Figure S49. ${ }^{1} \mathrm{H}$ NMR spectrum of 13 in $\mathrm{THF}^{-\mathrm{D}_{8}}$.

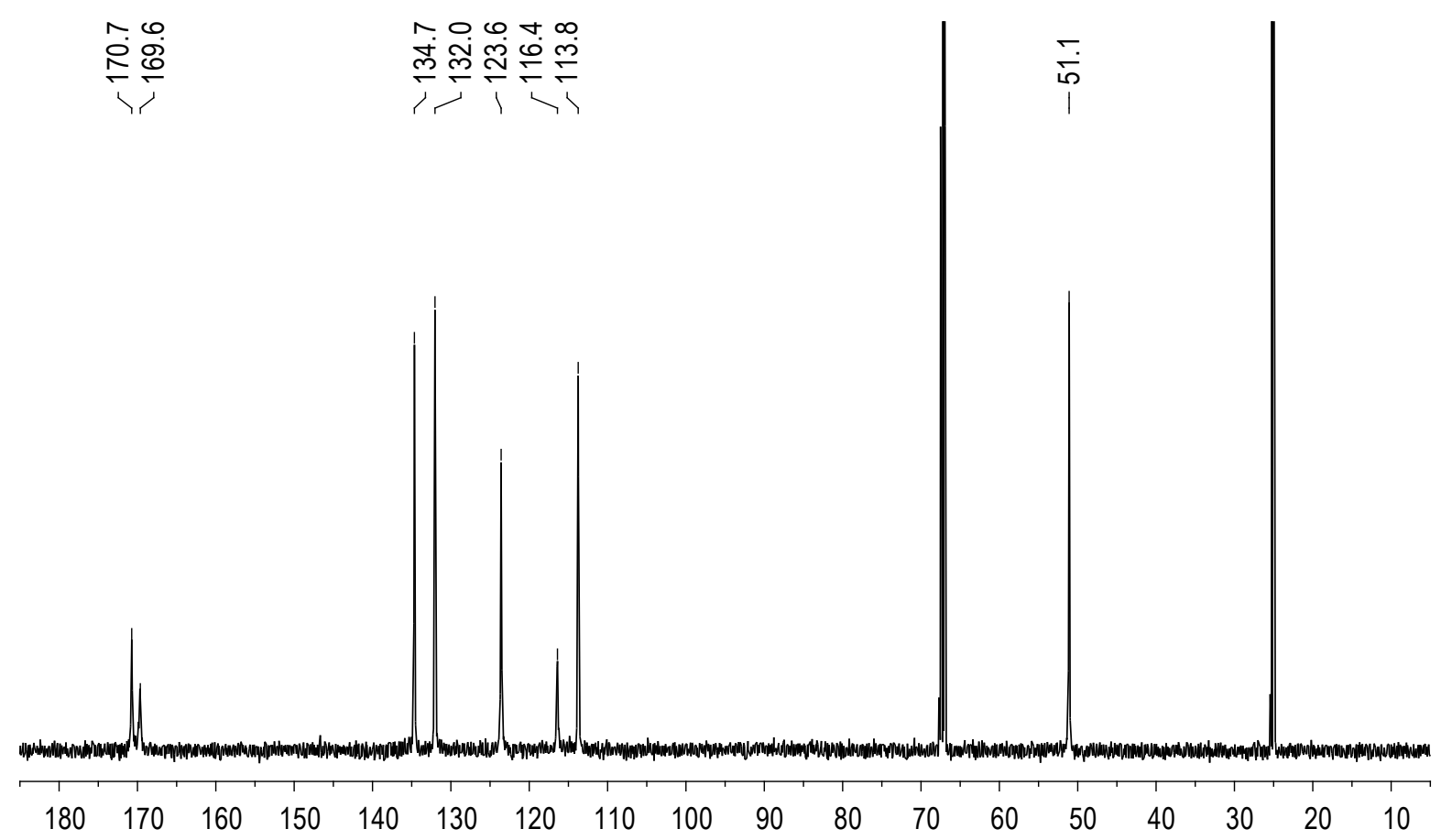

Figure S50. ${ }^{13} \mathrm{C}$ NMR spectrum of 13 in $\mathrm{THF}-\mathrm{D}_{8}$. 


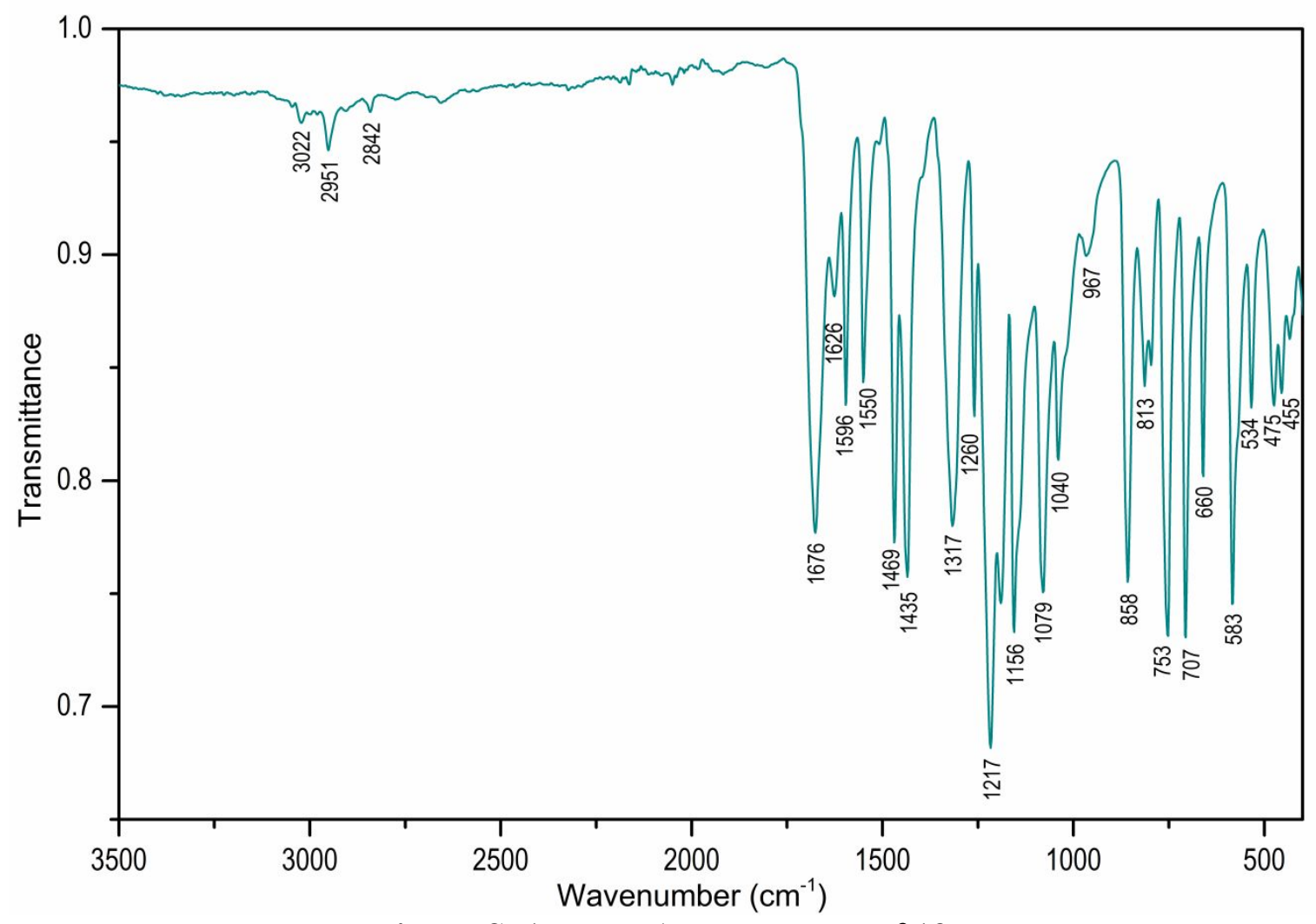

Figure S51. FTIR-ATR spectrum of 13.

Table S7. Catalytic solvothermal alcoholysis of high consistency SR using C9-C12 fatty alcohols and $\mathbf{1 0}$ as initiators at reactant stoichiometry $\left(\mathrm{OSiMe}_{2}\right) / \mathrm{ROH} / \mathbf{1 0}=1 / 2 / 0.01$ within 4h. ${ }^{\mathrm{a}}$

\begin{tabular}{|c|c|c|c|c|c|c|}
\hline No. & ROH & $\mathbf{P}_{\mathbf{1}}(\%)$ & $\mathbf{P}_{\mathbf{2}}(\%)$ & $\mathbf{P}_{\mathbf{3}}(\%)$ & $\mathbf{P}_{\mathbf{4}}(\%)$ & $\mathbf{P}_{\mathbf{m}}(\%)$ \\
\hline 1. & n-nonanol & 52 & 25 & 11 & 5 & 8 \\
2. & n-decanol & 42 & 26 & 14 & 7 & 11 \\
3. & n-dodecanol & 41 & 26 & 15 & 8 & 12 \\
\hline
\end{tabular}

${ }^{a}$ Alcoholysis conditions: 0.5g of SR (ELASTOSIL ${ }^{\circledR} \mathrm{R} 401 / 60 \mathrm{~S}$, Wacker Chemie AG) and from 4.7 to $6.1 \mathrm{~mL}$ of $\mathrm{ROH}$. Reaction performed using pressure reactor with a capacity of $25 \mathrm{~mL}$, with stoichiometry $\left(\mathrm{OSiMe}_{2}\right) / \mathrm{ROH} / \mathbf{1 0}=1 /(2-8) / 0.01$, under autogenous pressure of reactants, through $4 \mathrm{~h}$ at $220{ }^{\circ} \mathrm{C} .{ }^{b}$ Determined by GC-MS and corrected by the amount of isolated unreacted solid material.

1 Petrus, R.; Sobota, P. Zinc complexes supported by methyl salicylato ligands: synthesis, structure, and application in ring-opening polymerization of L-lactide. Dalton Trans. 2013, 42, 13838-13844.

${ }^{2}$ Petrus, R.; Fałat, P.; Sobota, P. Use of lithium aryloxides as promoters for preparation of $\alpha$-hydroxy acid esters, Dalton Trans. 2020, 49, 866-876. 